\title{
Heikki Ruohomaa
}

\section{Ecosystem-based}

development in the

transition of fourth

industrial revolution

$\Delta \Lambda$

ACTA WASAENSIA 452

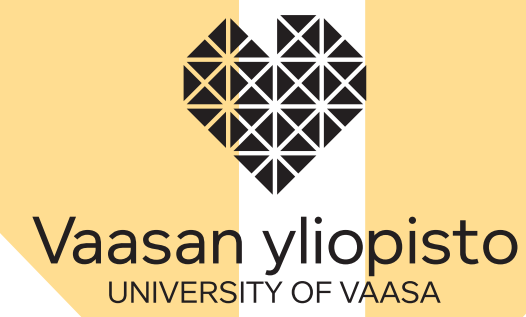




\section{ACADEMIC DISSERTATION}

To be presented, with the permission of the Board of the School of Technology and Innovations of the University of Vaasa, for public examination on the $9^{\text {th }}$ of December, 2020, at noon.

Reviewers Professor Dr Stefan Trzcielinskin

Poznan University of Technology

Faculty of Engineering Management

Department of Management Systems

2 J.Rychlewskiego Str.,

60-965 POZNAN

POLSKA / POLAND

Sosiaali- ja terveysjohtaja FT Harri Jokiranta

Seinäjoen kaupunki

Kirkkokatu 6, (PL215)

FI-60101 SEINÄJOKI

FINLAND 


\begin{tabular}{|c|c|c|}
\hline Vaasan yliopisto & \multicolumn{2}{|c|}{$\begin{array}{l}\text { Julkaisupäivämää } \\
\text { Marraskuu } 2020\end{array}$} \\
\hline & \multicolumn{2}{|c|}{ Julkaisun tyyppi } \\
\hline ORCID tunniste & \multicolumn{2}{|c|}{$\begin{array}{l}\text { Julkaisusarjan nimi, osan numero } \\
\text { Acta Wasaensia, } 452\end{array}$} \\
\hline $\begin{array}{l}\text { Yhteystiedot } \\
\text { Vaasan yliopisto } \\
\text { Tekniikan ja Innovaatiojohtamisen }\end{array}$ & $\begin{array}{l}\text { ISBN } \\
978-952-476 \\
978-952-476\end{array}$ & $\begin{array}{l}\text { (painettu) } \\
\text { (verkkoaineisto) }\end{array}$ \\
\hline & \multicolumn{2}{|c|}{ http://urn.fi/URN:ISBN:978-952-476-93 I-0 } \\
\hline talous & \multicolumn{2}{|c|}{$\begin{array}{l}\text { 0355-2667 (Acta Wasaensia 452, painettu) } \\
\text { 2323-9I23 (Acta Wasaensia 452, verkkoaineisto) }\end{array}$} \\
\hline & $\begin{array}{l}\text { Sivumäärä } \\
185\end{array}$ & \\
\hline \multicolumn{3}{|c|}{$\begin{array}{l}\text { Julkaisun nimike } \\
\text { Ekosysteeminen kehittäminen neljännen teollisen vallankumouksen murroksessa }\end{array}$} \\
\hline \multicolumn{3}{|c|}{$\begin{array}{l}\text { Tiivistelmä } \\
\text { Yhteiskunnat ympäri maailmaa ovat kohtaamassa valtavia muutoksia uusien teknolo- } \\
\text { gioiden ja eksponentiaalisesti kasvavien datavirtojen mahdollistamana. Samanaikaisesti } \\
\text { olemme kohtaamassa "pirullisia" ongelmia, kuten ilmaston muutos, väestönkasvu ja } \\
\text { resurssien rajallisuus. Muutoksen laajuudesta johtuen sitä kutsutaan neljänneksi } \\
\text { teolliseksi vallankumoukseksi. Muutos tulee olemaan nopea ja kompleksinen; se tulee } \\
\text { vaikuttamaan kaikkiin toimialoihin ja muuttaa elämämme perustavanlaatuisesti. } \\
\text { Tämän tutkimuksen aiheena oli löytää osa-alueet, joita voidaan hyödyntää ekosystee- } \\
\text { misen kehittämisen neljännessä teollisen ajan murroksessa. } \\
\text { Tutkimus muotoilee viitekehystä muutoksen hallintaan ja johtamiseen kompleksisessa } \\
\text { muutoksessa. Tavoitteena on parantaa alueen liiketoimintaympäristöä sekä mahdollistaa } \\
\text { kilpailuetua yrityksille. } \\
\text { Tutkimus hyödyntää soveltavan tutkimuksen keinoin konstruktiivista tutkimusotetta. } \\
\text { Ensisijainen tavoite mallin rakenteella oli kehittää holistinen ymmärrys neljännen teolli- } \\
\text { sen vallankumouksen aiheuttaman digitaalisen murroksen ymmärtämiselle ja rakentaa } \\
\text { makrotason viitekehys. } \\
\text { Tutkimuksessa on asetettu kolme tutkimusväittämää ja vastaukset näihin on saatu } \\
\text { konstruktiivisella tutkimuksella käyttäen kuutta toisiinsa linkitettyä kysymystä. } \\
\text { Väittämät on todennettu tapaustutkimuksilla ja jatkuvilla seurantatutkimuksilla. } \\
\text { Tapaustutkimukset on tehty Kanta-Hämeessä Suomen kasvukäytävällä eri kohteissa. } \\
\text { Keskeisin lisäarvo tällä tutkimuksella on osoittaa askeleet digitaalisen muutoksen hal- } \\
\text { lintaan ekosysteemisen kehittämisen kautta. Tämä voidaan nähdä horisontaalisena } \\
\text { ekosysteemisenä kehittämisprosessina, mutta myös vertikaalinen ekosysteemi- } \\
\text { integraatio on kuvattu. Toinen tärkeä lisäarvo on onnistunut muutoksen toteuttaminen } \\
\text { toiminnan eri ekosysteemisillä tasoilla. Tutkimus esittelee "Teollisuus } 4.0 " \text { viite- } \\
\text { kehyksen hyödyntämistä osana aluekehitysprosessia. }\end{array}$} \\
\hline & & \\
\hline
\end{tabular}





\begin{tabular}{|c|c|c|}
\hline $\begin{array}{l}\text { Publisher } \\
\text { Vaasan yliopisto }\end{array}$ & \multicolumn{2}{|l|}{$\begin{array}{l}\text { Date of publication } \\
\text { November } 2020\end{array}$} \\
\hline $\begin{array}{l}\text { Author(s) } \\
\text { Heikki Ruohomaa }\end{array}$ & \multicolumn{2}{|c|}{$\begin{array}{l}\text { Type of publication } \\
\text { Doctoral thesis by publication }\end{array}$} \\
\hline ORCID identifier & \multicolumn{2}{|c|}{$\begin{array}{l}\text { Name and number of series } \\
\text { Acta Wasaensia, } 452\end{array}$} \\
\hline $\begin{array}{l}\text { Contact information } \\
\text { University of Vaasa } \\
\text { School of Technology and }\end{array}$ & $\begin{array}{l}\text { ISBN } \\
978-952-476-930-3(P \\
978-952-476-931-0)(c\end{array}$ & \\
\hline & \multicolumn{2}{|c|}{ http://urn.fi/URN:ISBN:978-952-476-93 I-0 } \\
\hline $\begin{array}{l}\text { P.O. Box } 700 \\
\text { FI-65I0I Vaasa }\end{array}$ & \multicolumn{2}{|c|}{$\begin{array}{l}\text { ISSN } \\
\text { 0355-2667 (Acta Wasaensia 452, print) } \\
\text { 2323-9I23 (Acta Wasaensia 452, online) }\end{array}$} \\
\hline Finland & $\begin{array}{l}\text { Number of pages } \\
185\end{array}$ & \\
\hline \multicolumn{3}{|c|}{$\begin{array}{l}\text { Title of publication } \\
\text { Ecosystem-based development in the transition of fourth industrial revolution }\end{array}$} \\
\hline \multicolumn{3}{|c|}{$\begin{array}{l}\text { Abstract } \\
\text { Societies around the globe are facing enormous changes based on new technologies and } \\
\text { an exponential growth in the amount of data. At the same time, we are facing the } \\
\text { "wicked" problems of world, like climate change, population growth and the lack of } \\
\text { natural resources. Due to the importance and complexity of this transition, it is referred } \\
\text { to as the "fourth industrial revolution". The change will be fast and complex; it will affect } \\
\text { all sectors of society and fundamentally change the way we live. } \\
\text { The goal of this dissertation was to find the available parts of methodology and fine tune } \\
\text { them to create new concepts to build a framework for ecosystem-based development in } \\
\text { the transition of the fourth industrial revolution. At the same time, this dissertation } \\
\text { attempts to develop several frameworks for the strategic management of complex change } \\
\text { in order to achieve a competitive edge for companies and to improve the regional } \\
\text { business environment. } \\
\text { The study follows the constructive research approach which may be seen as a type of } \\
\text { applied science. The primary aim of model building was to develop holistic understanding } \\
\text { about the fourth industrial revolution transition and build a macro-level framework which } \\
\text { would work in principle, even if some detailed questions remained unanswered. } \\
\text { At the beginning of the dissertation, three research propositions were set out and } \\
\text { answers to these were sought according to conceptual constructive research by six } \\
\text { different interlinked questions. The propositions have been validated by case studies and } \\
\text { post-case study validating discussions: this is qualitative research based on a constructive } \\
\text { research approach. Case studies have been executed in Häme region on the Finnish } \\
\text { Growth Corridor. } \\
\text { The key contribution of this dissertation is to show the different steps of the strategy of } \\
\text { ecosystem-base development. This can be seen as a "horizontal ecosystem-based } \\
\text { development process". A second important contribution is to ensure proper imple- } \\
\text { mentation of change in transition. The importance of "vertical ecosystem integration" is } \\
\text { introduced. This dissertation also include the "Industry } 4.0 \text { " framework as part of the } \\
\text { regional development process to provide guidelines rather than rules. }\end{array}$} \\
\hline
\end{tabular}

\section{Keywords}

ecosystems, digitalization, fourth industrial revolution, smart specialization strategy, innovation, digital ecosystems, digital transformation 


\section{To my children}

Josefiina \& Casimir 


\section{ACKNOWLEDGEMENTS}

During the dissertation process it became evident that the researcher was not alone and without support and encouragement. Only of some of the supporters are mentioned here by name, but all of them deserve my warm thanks.

First of all, I wish to thank my supervisor prof. Jussi Kantola whose advice and positive comments gave me trust to finish this work.

I express my special thanks to my second supervisor, boss, work fellow, supporter Dr Vesa Salminen, who has opened me the world of science and helped me to make my lifetime dream became true.

My reviewers, Professor Stefan Trzcielinski (Poznan University of Technology) ja PhD Harri Jokiranta (Seinäjoki town) I wish to give my warm thanks for the fair and valuable comments they have given me during the evaluation process of this dissertation.

My family has seen this dissertation process and given me the time needed: Marja, Josefiina and Casimir, you have allowed me to take the time needed for conferences, writing papers and parts of this dissertation.

Akaa, October 2020

Heikki Ruohomaa 



\section{Contents}

ACKNOWLEDGEMENTS VII

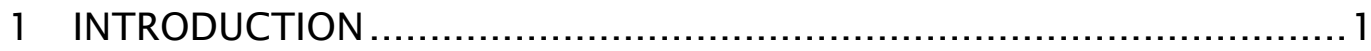

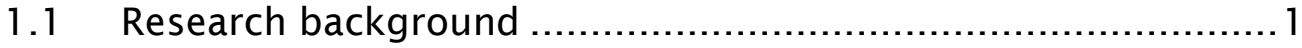

1.1.1 Fourth Industrial Revolution ...............................2

1.1.2 Smart Häme - Smart Specialization ........................ 4

1.2 Research gap ............................................................ 6

1.3 Problem formulation (building the theoretical framework) .......7

1.4 Research objectives, proportions and questions ..................11

1.4.1 Structure of dissertation work ............................ 14

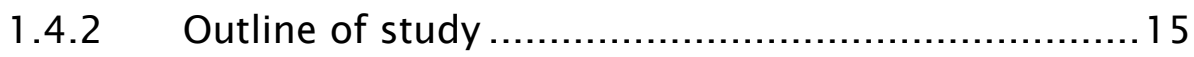

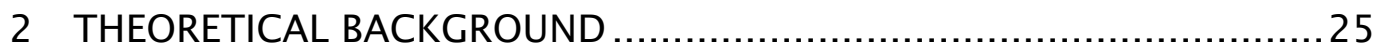

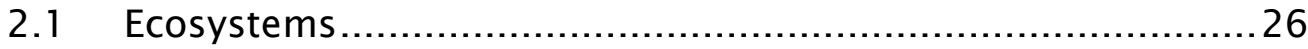

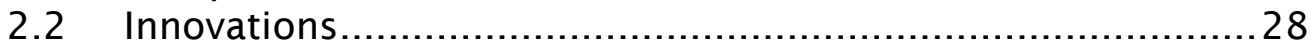

2.3 Smart Specialization Strategy ........................................ 30

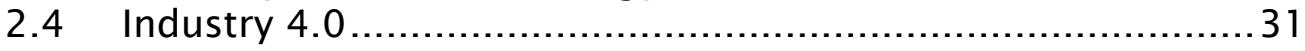

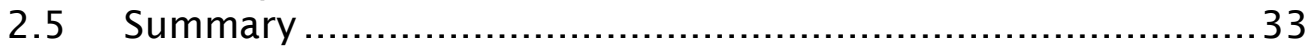

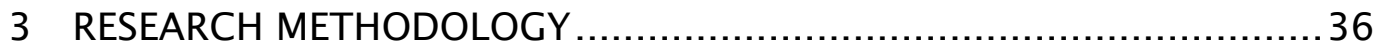

3.1 Research Philosophy and Approach ................................... 37

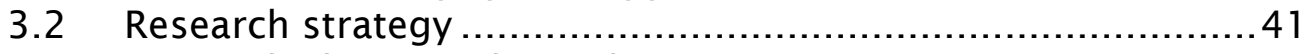

3.3 Research choice and time horizon ................................. 42

3.4 Data collection and analysis...........................................43

3.5 Summary of the research framework............................. 46

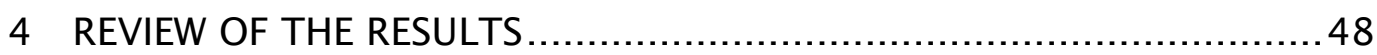

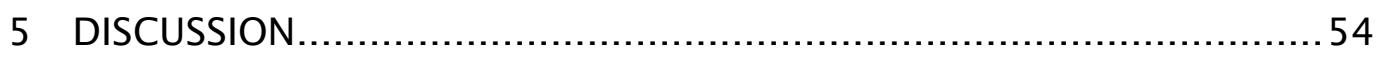

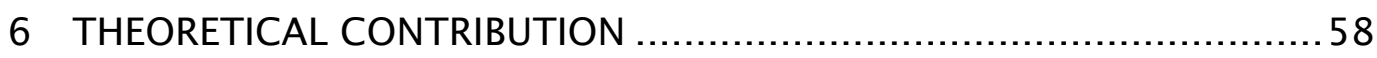

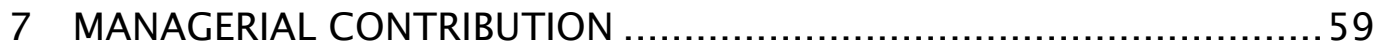

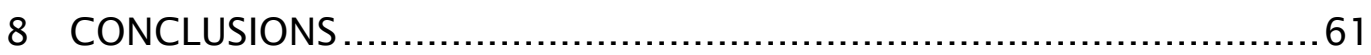

8.1 The limitations of the research ......................................6 61

8.2 Suggestions for future research ....................................6 62

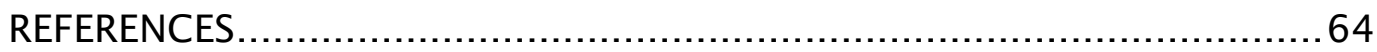


Figures

Figure 1. Fourth Industrial Revolution Technologies................... 2

Figure 2. Global growth trend of data 2010-2025 ...................... 3

Figure 3. Average year each tipping point (shift) would occur at some point in time World Economic Forum, Technology Tipping points and Societal Impact (2015))...................4

Figure 4. The funds that are used for research by region. .............. 6

Figure 5. Steps of ecosystem-based development process.............. 8

Figure 6. The change requires the interaction of ecosystems on all layers (vertical ecosystem)...................................... 10

Figure 7. Ecosystem-based development process .................... 11

Figure 8. The triangle of digital transformation in Industry 4.0 (Standardization Council) ......................................... 12

Figure 9. The proposal related to ecosystem-based development. . 13

Figure 10. Structure of thesis work ........................................ 14

Figure 11. Research propositions and related research questions and articles.............................................................. 16

Figure 12. Continuous spiral ecosystem-based development process. .................................................................. 35

\section{Tables}

Table 1. Overview of publications ......................................... 17

Table 2. Saunders' onion implemented in dissertation..................... 37

Table 3. Research choices ................................................. 40

Table 4. Data description ................................................. 43

Table 5. Principal phases of analysis ................................. 46

\section{Abbreviations}

$\begin{array}{ll}\text { HAMK } & \text { Häme University of Applied Sciences } \\ \text { 4IR } & \text { Fourth Industrial Revolution } \\ \text { I4.0 } & \text { Industry 4.0 } \\ \text { UAS } & \text { University of Applied Sciences } \\ \text { EU } & \text { European Union } \\ \text { CPS } & \text { Cyber Physical Systems } \\ \text { CPPS } & \text { Cyber Physical Production Systems } \\ \text { DSM } & \text { Digital Single Market } \\ \text { POC } & \text { Proof of Concept }\end{array}$




\section{Publications}

Publication A. Towards Smart City Concept in Small Cities

Authors: Heikki Ruohomaa, Vesa Salminen and Iivari Kunttu

Publisher TIM Review, September 2019, Volume 5 ( https://timreview.ca/article/1264)

Publication B. Renewing a University to Support the Adaptation of Industry 4.0 within a Region

Authors: Ruohomaa, Heikki, Mäntyneva, Mikko, Salminen, Vesa

Publisher IntechOpen, ISBN: 978-953-51-3842-6, DOI: 10.5772/intechopen.69336

Publication C. Value Network Development in Industry 4.0 Environment

Heikki Ruohomaa, and Jussi Kantola, Vesa Salminen, AFHE 2017, Florida, USA

Publisher Springer Nature, 2019, ISBN 3030201546, 9783030201548

Publication D. Ecosystem-based Development on Managing Digital Transformation Authors: Heikki Ruohomaa, Vesa Salminen

AHFE 2019 the Washington Hilton, Washington D.C. USA, July 24-28, 2019.

Publisher, Springer Nature, 2017 ISBN 3319603728, 9783319603728

Publication E. Regional Development in Modern Robotic Education on Industrial and Society Context

Authors: Ruohomaa Heikki, Salminen Vesa

AHFE 2018, USA. Orlando 21-24 July 2018

Publisher Springer Nature, 2018. ISBN 3319941968, 9783319941967

Publication F. Mobility as a Service in Smart Cities - New Concept for Smart Mobility in Industry 4.0 Framework

Authors: Heikki Ruohomaa, Vesa Salminen

ISPIM2018 Innovation for Local and Global Impact, 7-10 April, Ottawa, Canada

Publisher ISPIM 2018, - Electronic publication: ISBN 978-952-335-350-3.

Publication G. Ecosystem of Ecosystems in Intercity Biking

Authors: Heikki Ruohomaa, Vesa Salminen

AHFE2020 the San Diego July 16-21, 2020

Publisher Springer, Cham, 2020, Print ISBN 978-3-030-50790-9 Online ISBN 978-3-

030-50791-6

Publication H. 5G as a Driver for Transformation of Digitalization in Ecosystembased Development

Authors: Heikki Ruohomaa, Vesa Salminen

AHFE2020 the San Diego, July 16-21, 2020

Publisher Springer, Cham, 2020, Print ISBN 978-3-030-50790-9 Online ISBN 978-3-

030-50791-6 



\section{INTRODUCTION}

"The greatest danger of turbulence is not the turbulence - It is to act with yesterday's logic” Peter Drucker

\subsection{Research background}

This is the culmination of four years research that began in 2016 when HAMK University started to reorganize its applied research activities and establish a new research unit (HAMK Smart). The task of this unit is to respond to the transition of society towards the 4 th industrial revolution (4IR) caused by new ICT-based technologies and the exponential growth in data.

The purpose of HAMK Smart is to respond to the $4^{\text {th }}$ industrial revolution change, by developing education and by supporting companies and industrial sectors in field of digitalization and also by improving the business environment. HAMK Smart responds to the legal responsibilities of universities of applied sciences (UAS) in the region.

During the research period, the author of the thesis has been working as a research manager at the HAMK Smart Research Unit since it began. The author has had a front-line view to see the development of the HAMK Smart innovation ecosystem. In this four-year period, HAMK Smart has been involved in around 50 projects with around 100 customers.

The business ecosystems are dynamic networks of entities; clusters have similar features, but are mainly local networks.

During this time the author has written several articles and run several projects. The selected published articles form the basis of this thesis.

The dissertation work is based on observations, interviews and case studies to validate theoretical interrelationships. Several research or development projects have been tailored to exploit a new technology or idea in business. It has been noticed that new complex technology, needs "real life" testing and piloting in different environments and with different stakeholders who have a strong vision and a common goal.

The essential part of the different kinds of ecosystems is explained and referred to according to the theoretical discussion. 


\section{Acta Wasaensia}

The summary, this dissertation is based on the results of several projects executed over four years:

- Business incubator of circular economy

- Implementation of Industry 4.0

- Bioengineering education

- HAMK Smart Research Unit strategy work

- Traffic 4.0

- Circular Economy 4.0

- iCOINS

- $\mathrm{BIKE}$

The published articles are based on the observations and research of several projects.

\subsubsection{Fourth Industrial Revolution}

The expression "Industry 4.0" contains the promise of a $4^{\text {th }}$ industrial revolution. In future, as Industry 4.0 opens up, computers are connected and communicate with one another, in the end, to make decisions without human involvement. Everything will be connected virtually, if possible, and virtual world and physical world will be connected. This will transform whole economies and societies and our behavior.

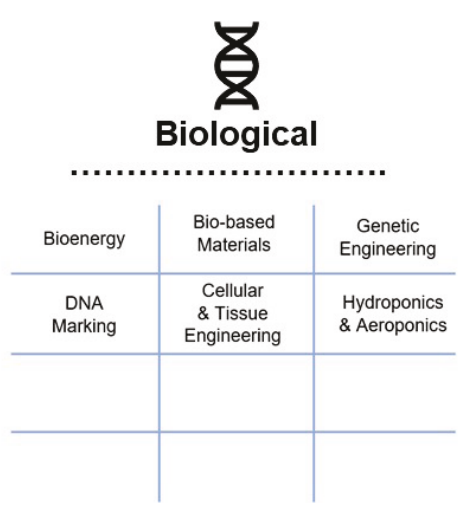

Technologies based on biology, aspects including but not limited to biological systems, living organisms, or derivatives thereof, to make products and processes for specific use
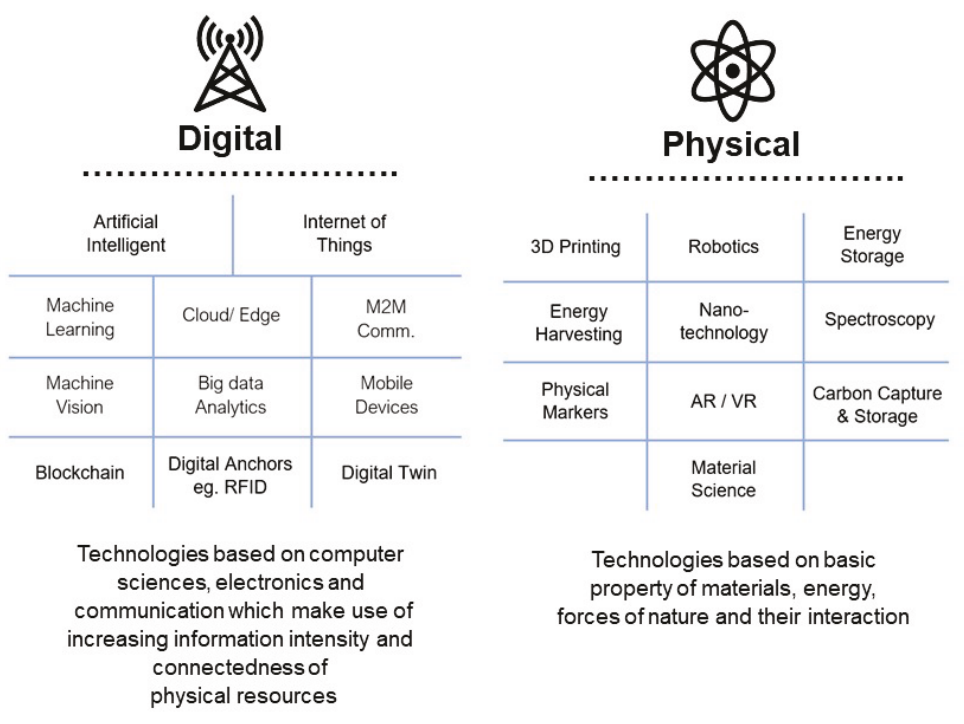

Figure 1. Fourth Industrial Revolution Technologies 
It is estimated data creation will increase to a huge 175 zettabytes (ZB) by 2025 . This is ten times the amount of data generated in 2017 (Reinsel et al., 2018).

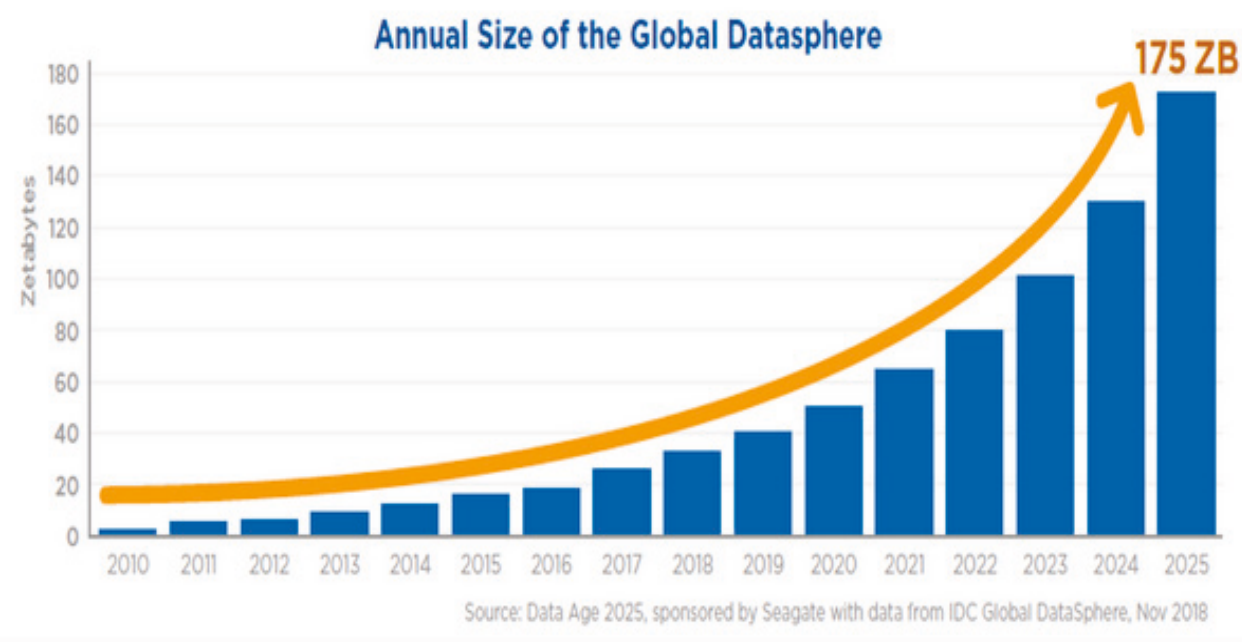

Figure 2. Global growth trend of data 2010-2025

The 90\% of the data, in the world has been created in the last two years alone, daily basis 2.5 quintillion bytes of data is collected.

It is predicted that the $60 \%$ of the world's data is collected via applications relying on artificial intelligence, and machine-to-machine technologies, automation and the increase of data collection from smart devices.

It can be seen that "the average rate per capita of data-driven interactions per day is expected to increase 20-fold in the next 10 years as our homes, workplaces, appliances, vehicles, wearables and also implants become data enabled" (Reinsel, D., 2018).

The conclusion of the increase is that data is progressively a critical influencer for all aspects of our lives. Smart devices and IoT are already promoting the amount of "life critical" data.

The ICD Research has given some estimation by year 2025:

- The number of smart devices will grow from one per person to four in the next eight years.

- The average person will interact nearly 5000 times a day with a connected device in seven years

- The $75 \%$ of the people of world will be connected with data. 
- Data will be available everywhere immediately.

- Over 25 percent of data created in the globally is in real time.

- The $95 \%$ of this is real-time data, which came from IoT

- New risks will rise to private and sensitive information when new data sources will be opened.

- Near $90 \%$ of all data created in the globally will need security, only part will be secured.

- The $20 \%$ of the data in the worldwide might be critical to the stability of our lives.

Therefore, it is essential to ensure that businesses and business environments are aware of where and how data growth is happening and are ready to manage data effectively and ensure that benefits have achieved

In addition to the societal impact, poorly managed increasing amount of data could result losing revenue in existing business by having operational inefficiencies and bad customer experience. By 2025 over $20 \%$ of the data collected globally could be useful for analytics. (Reinsel et al., 2018).

World Economic Forum research, results show that a remarkable number of new technologies were expected to take place in the coming years.

\begin{tabular}{|c|c|c|c|c|c|c|c|}
\hline 2018 & 2021 & 2022 & 2023 & 2024 & 2025 & 2026 & 2027 \\
\hline $\begin{array}{l}\text { - Storage for } \\
\text { All }\end{array}$ & $\begin{array}{c}\text { - Robot and } \\
\text { Services }\end{array}$ & $\begin{array}{l}\text { - The Internet } \\
\text { of and for } \\
\text { Things } \\
\text { - Wearable } \\
\text { Internet } \\
\text { - 3D } \\
\text { Printing and } \\
\text { Manufacturing }\end{array}$ & $\begin{array}{l}\text { - Implantable } \\
\text { Technologies } \\
\text { - Big Data for } \\
\text { Decisions } \\
\text { - Vision as the } \\
\text { New Interface } \\
\text { - Our Digital } \\
\text { Presence } \\
\text { - Governments } \\
\text { and the } \\
\text { Blockchain } \\
\text { - A } \\
\text { Supercompute } \\
\text { Your Pocket }\end{array}$ & $\begin{array}{l}\text { - Ubiquitous } \\
\text { Computing } \\
\text { - 3D Printing } \\
\text { and Human } \\
\text { Health } \\
\text { - The } \\
\text { Connected } \\
\text { Home } \\
\\
\text { in in }\end{array}$ & $\begin{array}{l}\text { - 3D Printing } \\
\text { and } \\
\text { Consumer } \\
\text { Products } \\
\text { - Al and } \\
\text { White-Collar } \\
\text { Jobs } \\
\text { - The Sharing } \\
\text { Economy }\end{array}$ & $\begin{array}{l}\text { - Driverless } \\
\text { Cars } \\
\text { - Al and } \\
\text { Decision- } \\
\text { Making } \\
\text { - Smart Cities }\end{array}$ & $\begin{array}{l}\text { - Bitcoin } \\
\text { and the } \\
\text { Blockchain }\end{array}$ \\
\hline
\end{tabular}

Figure 3. Average year each tipping point (shift) would occur at some point in time World Economic Forum, Technology Tipping points and Societal Impact (2015))

\subsubsection{Smart Häme - Smart Specialization}

Smart specialization strategy is needed for regional development and to allocate regional EU funding resources to actors. Through Smart Häme cooperation, we 
will bring together regional strengths to support regional research and the use of innovation funding (Häme Regional Council, 2020).

Every region in Europe has its own strengths and those are marketing its strengths nationally and internationally. By focusing on their own strengths and with the cooperation of different sectors, it is possible to achieve better outcomes from research and innovation work.

Smart Häme strategy has four focus areas:

- Smart Bioeconomic (sustainable use of natural resources, bio- and circular economy, smart agriculture and food processing)

- Smart Factory (Industry 4.0, internet of things, robotics, smart manufacturing)

- Smart City (Built environment, environment friendly buildings, smart traffic)

- Creative Economy (arts, tourism, culture, wellbeing, sports, smart services)

The cooperation between different sectors and different stakeholders is essential.

The strategy is much more likely to be successful and create new innovation to develop new business, new product and new services.

\section{Research and development activities in Häme region}

R\&D funding compared to turnover, has been lower in companies in Häme region than the average across Finland. The goal has been to increase R\&D investment in companies. R\&D funding and the number of research staff have been decreasing since 2013. In 2018 the R\&D funding in Häme region was sixth lowest in the whole of Finland. Häme region received only one percent of the total Finnish R\&D funding. 


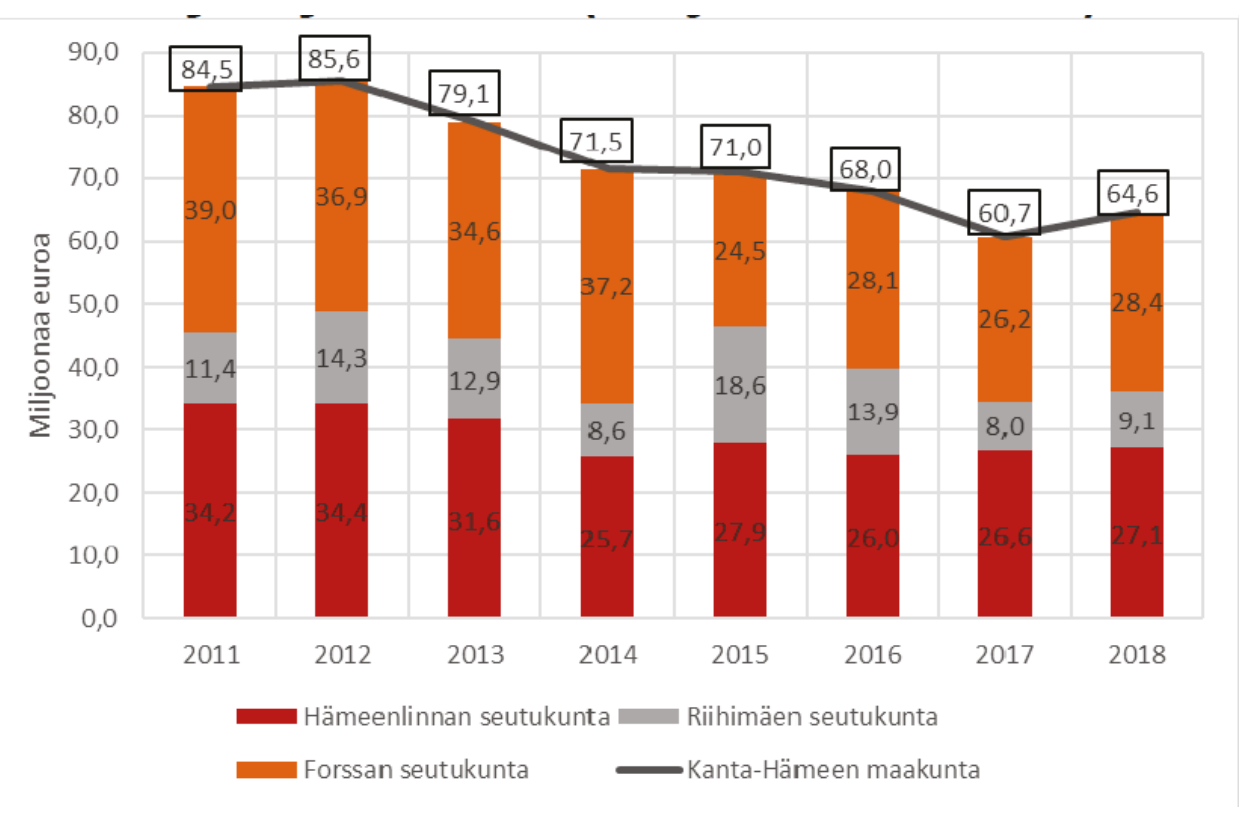

Figure 4. The funds that are used for research by region.

\subsection{Research gap}

Societies globally are facing enormous changes based on new technologies, and an exponential growth in the amount of data. At the same time, we are facing the "wicked" problems of world, like climate change, population growth and the lack of natural resources. Due to the importance and complexity of this transition, it is referred to as the " $4^{\text {th }}$ industrial revolution" ( $\left.4 \mathrm{IR}\right)$. The change will be fast and complex; it will affect all sectors of society and fundamentally change the way we live.

There are currently two areas, in human history, that are both having radical and unprecedented change. One is the quickly evolving, deeply systemic technological revolution. The second is the quickly worsening systemic social and ecological crisis (Cole et al., 2019).

Changes in value chains, services, business models and ecosystems will be based on exponential growth of data. The development requires greater connection and collaborations, which means the "explosion" of platforms and ecosystems. (PwC report 2016).

The new technologies of the $4^{\text {th }}$ industrial revolution have the potential to change the global competition of production (World Economy Forum 2019). 
The boundaries between the real physical world and the virtual one is blurring because of the fast adoption of communication and information technology. The connection is becoming increasingly smart (Lusch, F. et al., 2016).

The move to Industry 4.0 and the ongoing transformation of enterprises to adopt cloud, IoT and advanced wireless networking options, is a massive undertaking. It will demand strong partnerships between industry and ecosystems that are more diverse and more cohesive than we have ever seen before. (IoT Community 2019)

Anyhow, there is little awareness of Industry 4.0, in the field of social change, outside the key stakeholders, while unions have reservations and remain cautious, larger companies seems to be more motivated to the changes. The skills requirement to adjust to Industry 4.0 is much greater, although a skills gap in the Digital Single Market exists (as well as a gap in willingness to adjust), (European Parliament, Briefing 2015).

Thus, it is important to develop suitable methodologies for fast and complex change in business and in society as a whole. The change we are facing has features that we have not faced ever before. This dissertation focuses on developing an ecosystem-based concept to manage the transition on the stage of $4^{\text {th }}$ industrial revolution. At the same time, it attempts to develop framework for the strategic management of complex change, in order to be able to improve the regional business environment and to achieve a competitive edge for companies.

\subsection{Problem formulation (building the theoretical framework)}

The main research question is, "Ecosystem based development in the transition of fourth industrial revolution" (sub questions are shown on page 14.). To be able to answer the main research question, the phenomenon behind the existing problem must be identified. In this study, the objective is to form a model and test the elements/actions/operation which are needed to manage the change. In order to reach this goal, the study starts with the development of a theoretical framework for research.

There are three main background theories influencing this study: a) smart specialization in order to allocate resources appropriately, b) innovation theory to make implementation possible, $\mathrm{c}$ ) ecosystem theories to respond to the complex and changing environment. 


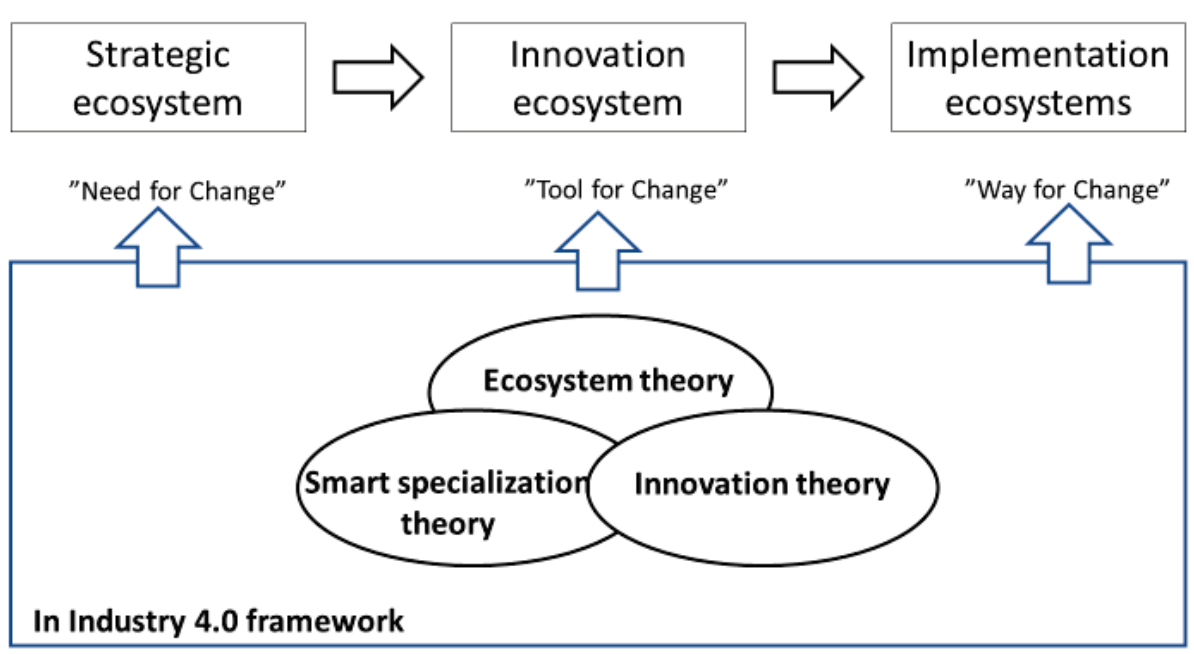

Figure 5. Steps of ecosystem-based development process.

Strategic ecosystem: managing the strategic change

In this stage, it is strategically important to create a common understanding about future trends on which to build vision and strategies among the key stakeholders in the region. This is the key step to improve innovativeness in order to respond to the complex change and thus increase the competitiveness of the business environment. Based on this, "smart specialization strategy" has been selected as the key strategy, because it allocates regional development resources based on the business strengths of area/region. In addition, smart specialization strategy combines the strategies of towns by region and the legal task of applied research and regional development of UAS also by region (Open innovations, triple helix clusters).

Smart specialization strategy forces key actors (universities, cities, government) to find common goals and means for development in order to secure EU funding. Thus, we can consider that this is the ecosystem which will implement strategic decisions.

By clarifying the background of the change (trends) and the local ecosystems for strategic change, it is easier to understand the drivers for the change and to see the role and mission of each actor. By creating a common vision and uniting the strength and strategies of each actor, it is possible to allocate resources. 
Publications A and B describe elements for strategic views and elements of the cooperation of the key actor (government, enterprises, educators and municipalities).

Innovation ecosystem: managing the knowledge and innovation

It is important in this stage to build the readiness for the change by developing an innovation ecosystem. In the theoretical framework, it is important to identify the innovation process in all sectors/industries, since innovation will often take place at interfaces of different sectors/industries. In addition, disruptive innovations will change the business landscape.

The innovation ecosystem will act as "the tool for change" and build the bridge from strategic decision-making to implementation ("strategic ecosystems" to "implementing ecosystems") and show how regional vision is implemented in local organizations through smart specialization strategy, building knowledge and implementing actions by projects.

In publications $\mathrm{C}, \mathrm{D}$ and $\mathrm{E}$, not only are innovation ecosystems and the role of local UAS as supporting local industries discussed, but also the role of the HAMK Smart Research Unit as the core of the local innovation ecosystem.

Implementation ecosystems: implementing the change

In this stage, understanding is developed of the way that the different ecosystems should be combined in order to make sustainable change possible in industry/society.

By forming the model for implementation through different layers, it can be seen that the innovation ecosystem is one of the ecosystems which combines the digital ecosystem with the business ecosystems. It must be remembered that there is an "infra ecosystem" to develop the infrastructure (which is continuously on the move), and it must be noted that the meaning of ecosystem (e.g., legislation, rules etc.) gives the rules for business ecosystems to operate in a sustainable way. 


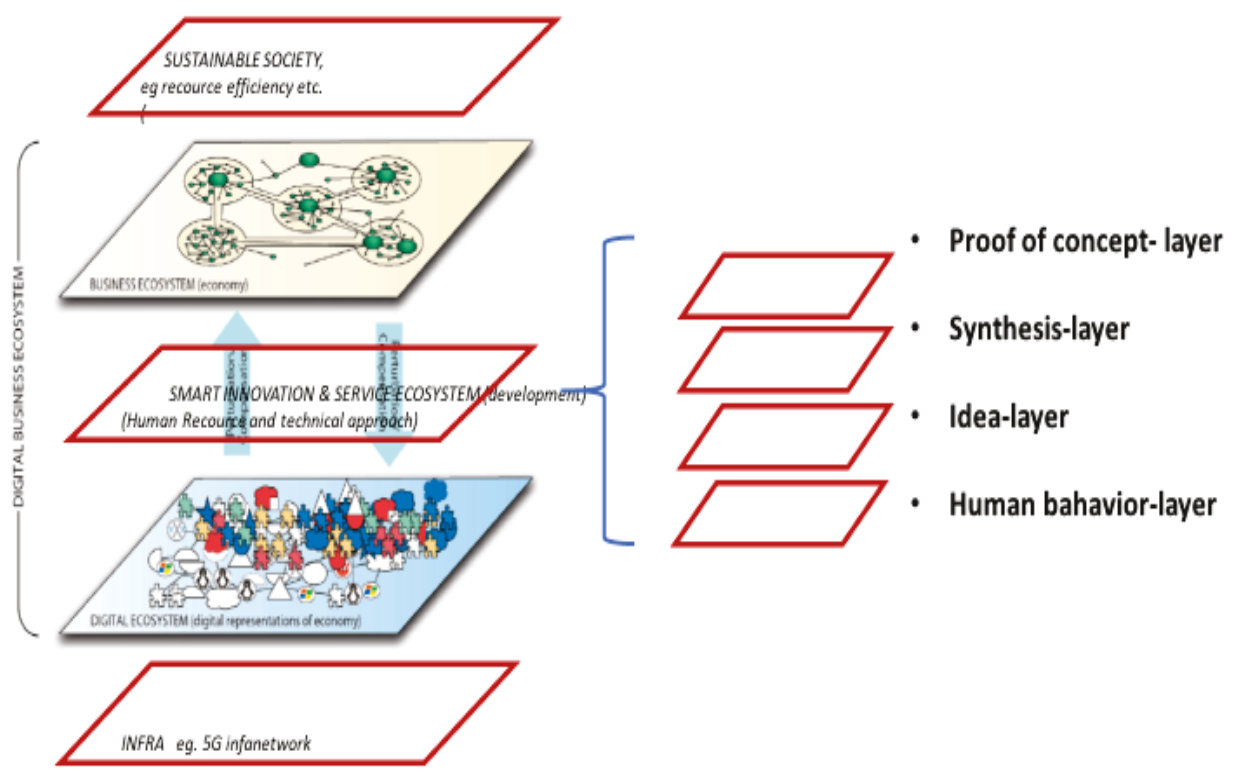

Figure 6. The change requires the interaction of ecosystems on all layers (vertical ecosystem).

In publications $\mathrm{G}, \mathrm{H}$ and $\mathrm{F}$ the interaction of different ecosystems and their harmonization has been discussed.

\section{The process of ecosystem-based development}

In this stage it is necessary to understand the continuum of ecosystem-based development processes and the importance of different ecosystems in this framework.

It is important to combine ecosystems to show the meaning of different ecosystems on the horizontal time frame. It is essential to show different stages of ecosystembased development in order to build a holistic view about ecosystem-based development in one region on the Finnish Growth Corridor. 


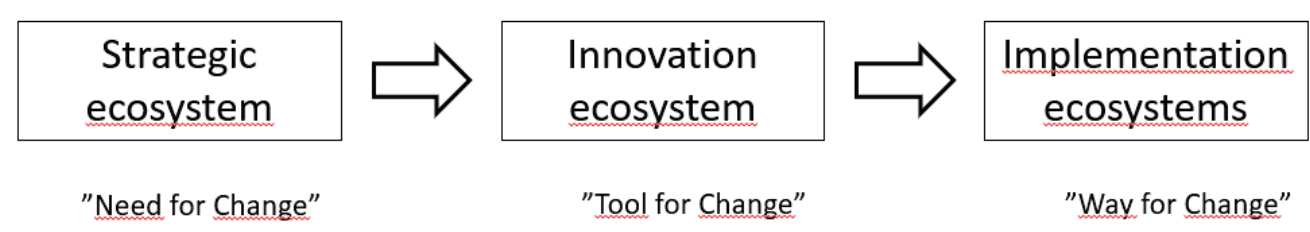

Figure 7. Ecosystem-based development process

Presented articles describe the continuous change in ecosystem-based development (horizontal ecosystem).

\subsection{Research objectives, proportions and questions}

The goal of this dissertation is to understand the change in the $4^{\text {th }}$ industrial revolution, how it will change the current situation, and how we should be prepared for transition. The research focused on Häme region on the Finnish Growth Corridor, but the result can be utilized also in other environments/areas.

It is understood that the $4^{\text {th }}$ industrial revolution will bring new revolutionary technologies and a huge quantity of data. This will have a great effect on all the selected focus areas of smart specialization in the region. At the same time, we might see that the $R \& D$ funding is not growing in this region as expected. Since the changes are complex and fast and the R\&D funding is lacking, there is an immediate need to find new ways to respond to the transition and to allocate resources to facilitate the changes.

Thus, it is important to understand the ecosystem-based change in the complex and fast-changing era of the $4^{\text {th }}$ industrial revolution transition by new ICT-based technologies and huge increasing amount of data. The research propositions are formulated based on factors which are given for digital transformation on the Industry 4.0 framework but also the smart specialization strategy framework for regional innovations by the EU. The first proposition is based on the importance of strategy and vision (also regional vision). The second proposition is based on the importance of transdisciplinary piloting and testing environments. The third proposition is related to harmonization of data. 


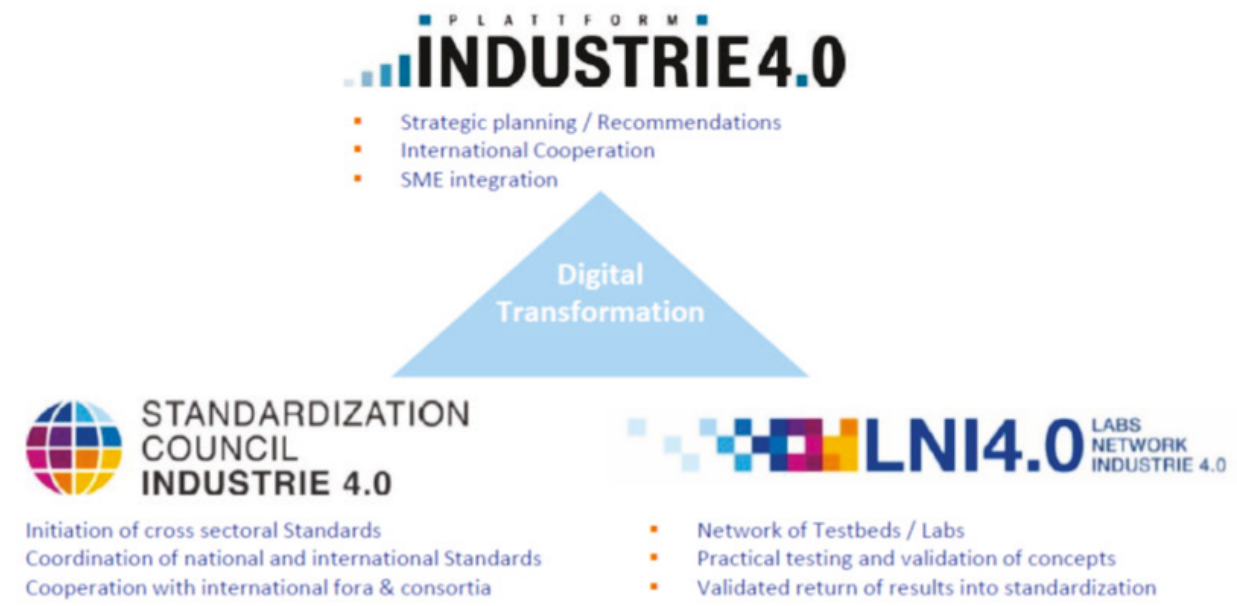

Figure 8. The triangle of digital transformation in Industry 4.0 (Standardization Council)

The problems foreseen in the transition of the $4^{\text {th }}$ industrial revolution are complex and unprecedented. The complexity, the speed the change and the new technologies, mean that an ecosystem-based approach is considered to function as a framework for development. There are many ecosystems present and they are interacting and changing all the time. This has led to following research propositions:

P1. Ecosystem-based change requires strong commitment and vision from all partners.

P2. Complex and fast-moving change needs transdisciplinary innovation, education and piloting environments.

P3. The re-engineering of business ecosystems and the change in society requires that all the ecosystems support the transition.

The first proposition deals with building a common understanding and vision and getting commitment from the key stakeholders (companies, cities, government/municipalities, educators) so they can follow ecosystem-based ways by themselves and give a solid basis for future ecosystem work. The second proposition deals with the innovation ecosystem and how strategic goals are connected to regional development and smart specialization strategy. This deals with introducing knowledge and education into the company development projects. The third proposition deals with the implementation of change into practice and the involvement of different ecosystems in the process of transition.

Confirmation of the research propositions has been sought through the following research questions. The methodological work has been introduced in the eight 
articles to build a framework for ecosystem-based development at the time of transition to the fourth industrial revolution.

The questions are:

Q1. How can we prepare for change and develop a common vision of a strategy?

Q2. Does a smart specialization strategy provide the guidelines for allocating resources?

Q3. How can we integrate applied research for regional development? Q4. How can education change to respond to the needs of the fourth industrial revolution?

Q5. How should digital ecosystems and data be structured?

Q6. How should data be combined in ecosystems and different sectors?

It is important to see ecosystem-based development as a powerful tool to manage complex and fast change. The nature of ecosystem-based development is that there are different ecosystems involved during various times of action/development. Ecosystems will change over time and stakeholders may be members of different ecosystems.

The research questions were used to find evidence in support of the research propositions.

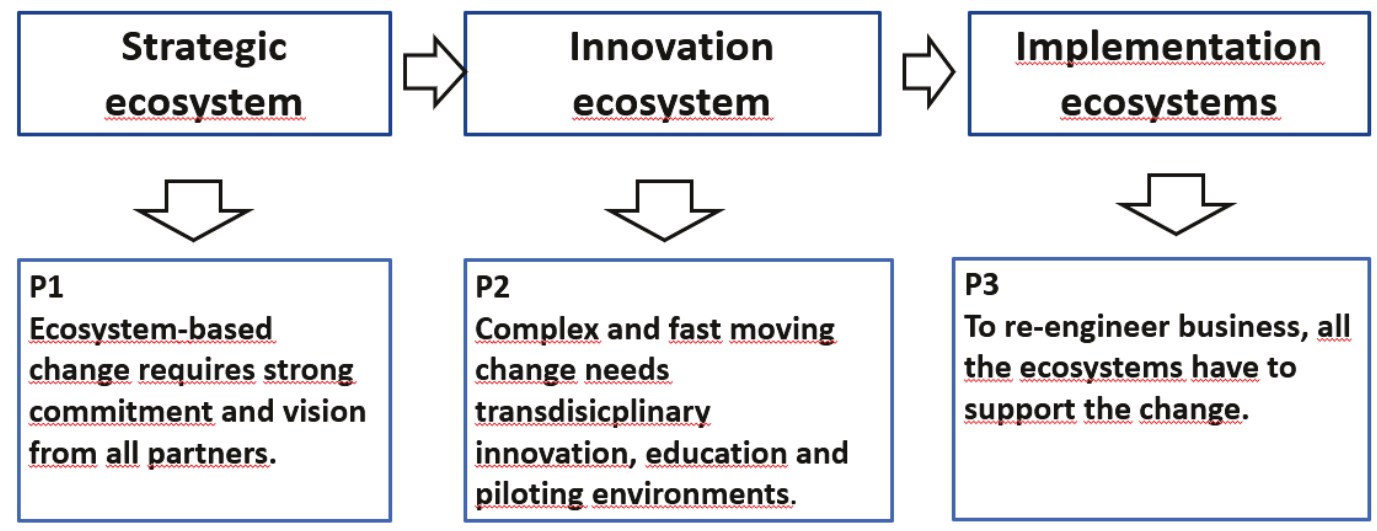

Figure 9. The proposal related to ecosystem-based development.

The framework for ecosystem-based development for the transition to the $4^{\text {th }}$ industrial revolution has been validated through the case studies introduced in the eight publications based on earlier research. 


\subsubsection{Structure of dissertation work}

This dissertation is based on a framework created during several projects over the past four years. Theories, concepts, methods and tools related to the title "Ecosystem-based development in the transition of the fourth industrial revolution" were analysed first.

Three search propositions were made according to the analysis and six research questions were raised to guide the research and validate the work. The available concepts were analysed and adjusted to best describe the transition. Workshops have been held to get a better understanding of the change and its key elements. The new concept was developed according to theoretical validity and according to the understanding of suitability and interpretation of change.

Figure 10 shows the work behind the process and behind the thesis. Various theories and methods and their sustainability with respect to the dynamic transition of society and business were analysed first. The ecosystem-based development method, consisting of several methods and concepts, was constructed from various theories and practices.

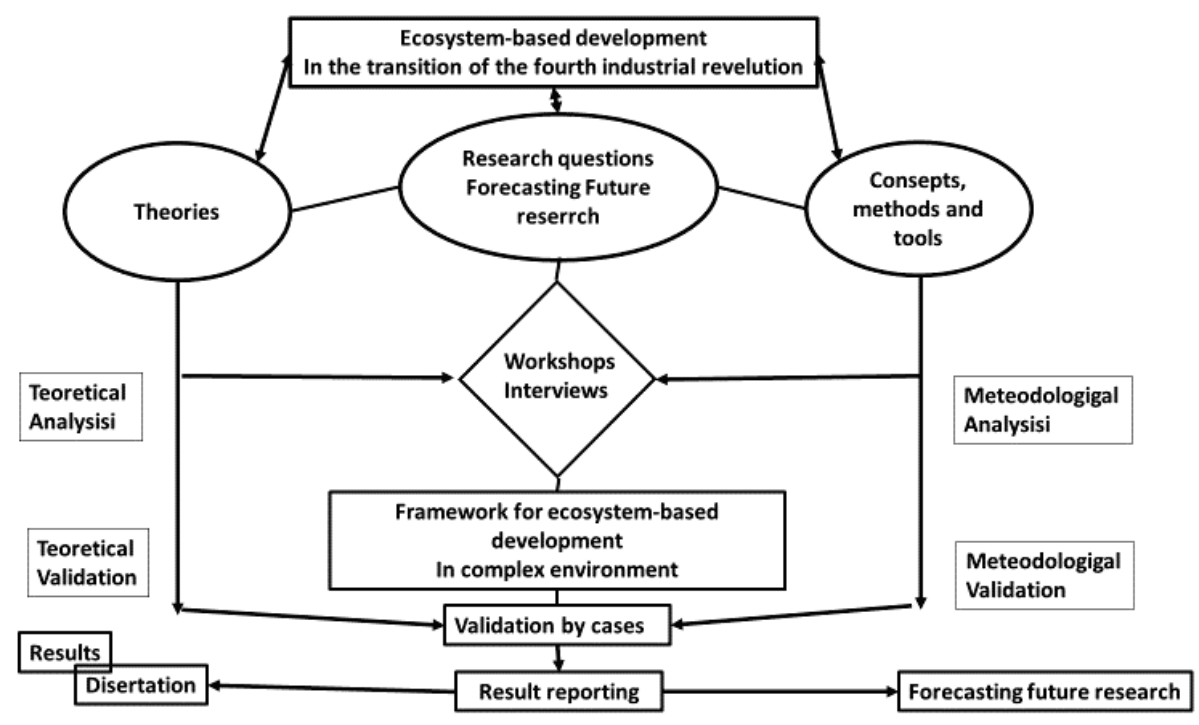

Figure 10. Structure of thesis work

This work is based on both constructive and conceptual research. This research is partly conceptual and analytical, because it introduces a new concept. P1, P2 and $\mathrm{P}_{3}$ form and describe the content of fast and complex change by ecosystem-based development. 
Scientific research methods have been used to address problems of complex change that have not been faced before. This opens up new fields of applied research and indicates some possible opportunities to for future work.

This current work is based on the results of the following projects that were introduced earlier: 1) Industry 4.0, a project with a framework to see how the Industry 4.0 framework could be implemented in Häme region, 2) Circular Economy Village at Riihimäki, a project to analyse of the development and competitiveness of circular economy villages and industrial symbiosis, 3) WAIKATO, a project to benchmark the best practices in New Zealand, 4) TRAFFIC 4.0, a project to utilize the data in developing traffic and building new models for mobility, 5) 5G Start, a project to utilize new $5 \mathrm{G}$ technology for city development and building a new piloting environment, 6) BIKE, a project involving the growth of the common biking ecosystem in the Finnish Growth Corridor, 7) Developing HAMK Smart Research Unit project, 8) developing bioengineering education, 9) iCOINS, a project to build international education for Industry 4.o.

All these projects form the framework for concept development (mapping) and influence the framework for ecosystem-based development.

In addition to all the projects mentioned above, the researcher has been able to observe the development as an insider and has been able to participate to decisionmaking.

\subsubsection{Outline of study}

In order to be able to answer to main research question we examine the opportunities and methods for managing the complex and fast change in society at all levels. The main goal of the research and its relationship to the research questions, are presented in Figure 11. The publications have been structured to answer the research questions following the strategic approach of the research. 


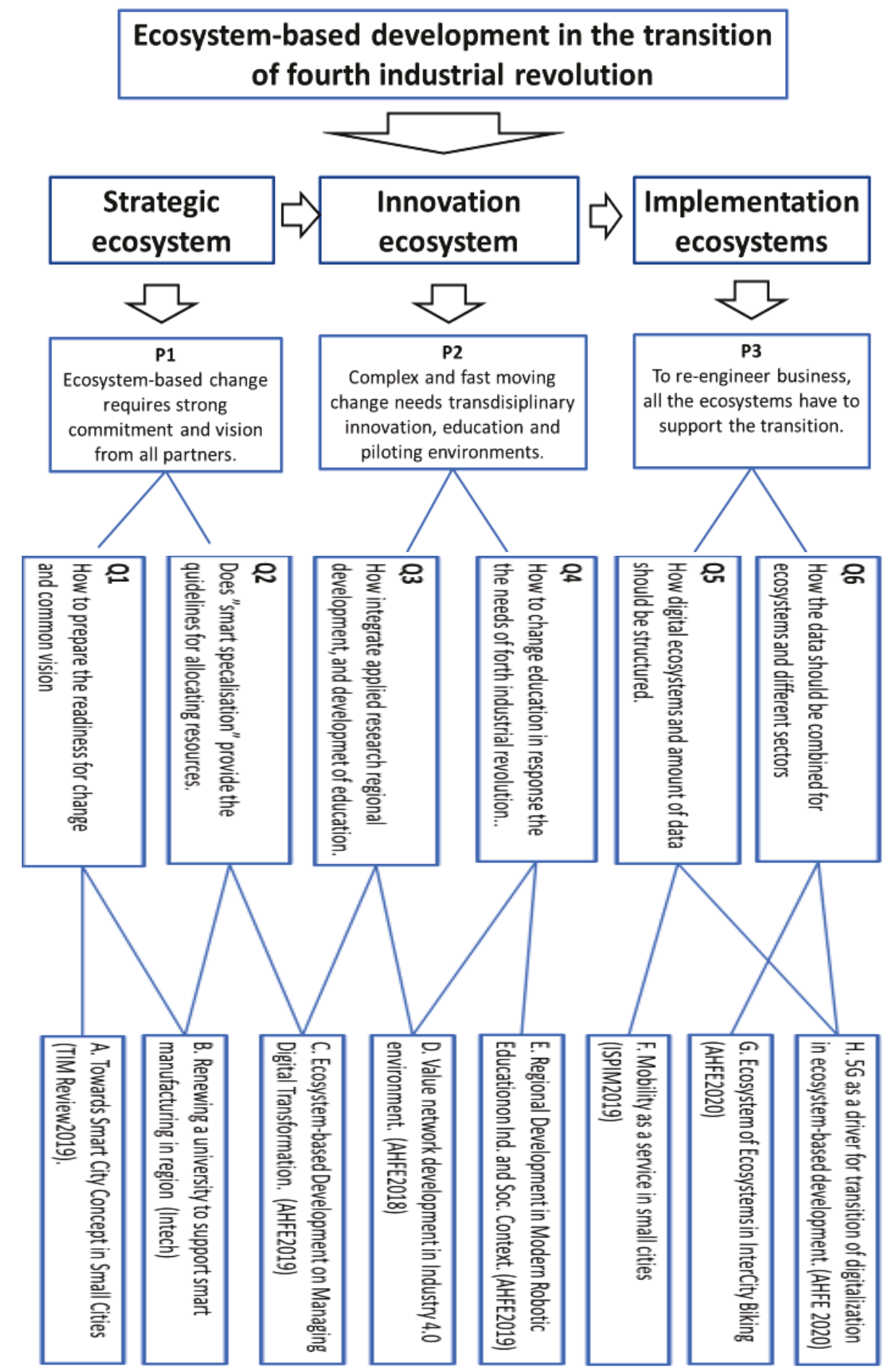

Figure 11. Research propositions and related research questions and articles 
The publications introduced in this dissertation have been presented at academic conferences and in scientific publications. They have had routine scientific evaluation before selection.

Results of the publication validate the corresponding research propositions. The process begins by analysing the element and nature of the arriving change. The process of change has been observed since 2016. Observations and results have been published in articles. An overview of publications is given in Table 1.

Table 1. Overview of publications

\begin{tabular}{|c|c|c|c|c|c|c|}
\hline & Publication title & $\begin{array}{l}\text { Research } \\
\text { question }\end{array}$ & $\begin{array}{l}\text { Theoretical } \\
\text { perspective }\end{array}$ & $\begin{array}{l}\text { Empirical } \\
\text { context }\end{array}$ & $\begin{array}{l}\text { Research } \\
\text { design }\end{array}$ & Key findings \\
\hline $\mathrm{A}$ & $\begin{array}{l}\text { Towards Smart City } \\
\text { Concept in Small Cities }\end{array}$ & $\begin{array}{l}\text { Ecosystem } \\
\text { development in } \\
\text { small cities }\end{array}$ & $\begin{array}{l}\text { Ecosystem } \\
\text { theory }\end{array}$ & $\begin{array}{l}\text { Strategies in } \\
\text { small town in } \\
\text { the region }\end{array}$ & $\begin{array}{l}\text { Multiple } \\
\text { qualitative } \\
\text { case study }\end{array}$ & $\begin{array}{l}\text { New technology } \\
\text { and industrial } \\
\text { symbiosis as key } \\
\text { drivers }\end{array}$ \\
\hline $\mathrm{B}$ & $\begin{array}{l}\text { Renewing a university } \\
\text { to support smart } \\
\text { manufacturing in region }\end{array}$ & $\begin{array}{l}\text { How to improve } \\
\text { competitiveness } \\
\text { of region }\end{array}$ & $\begin{array}{l}\text { Smart } \\
\text { specialization } \\
\text { strategy and } \\
\text { Industry } 4.0\end{array}$ & $\begin{array}{l}\text { enterprise - } \\
\text { university - } \\
\text { municipality } \\
\text { partnership } \\
\text { in HAME }\end{array}$ & $\begin{array}{l}\text { Multiple } \\
\text { qualitative } \\
\text { case study }\end{array}$ & $\begin{array}{l}\text { Industry } 4.0 \text { will } \\
\text { give a } \\
\text { framework for } \\
\text { development }\end{array}$ \\
\hline $\mathrm{C}$ & $\begin{array}{l}\text { Ecosystem-based } \\
\text { development of } \\
\text { managing digital } \\
\text { transformation }\end{array}$ & $\begin{array}{l}\text { Does digital } \\
\text { transition lead to } \\
\text { ecosystem-based } \\
\text { development } \\
\text { processes? }\end{array}$ & $\begin{array}{l}\text { Ecosystem- } \\
\text { based } \\
\text { development }\end{array}$ & $\begin{array}{l}\text { Hämeenlinna } \\
\text { "Smart City" }\end{array}$ & $\begin{array}{l}\text { Multiple } \\
\text { qualitative } \\
\text { case study. }\end{array}$ & $\begin{array}{l}\text { The need for an } \\
\text { innovation } \\
\text { ecosystem }\end{array}$ \\
\hline $\mathrm{D}$ & $\begin{array}{l}\text { Value network } \\
\text { development in } \\
\text { Industry } 4.0 \\
\text { environment }\end{array}$ & $\begin{array}{l}\text { How to ensure } \\
\text { the change and } \\
\text { innovations }\end{array}$ & Industry 4.0 & $\begin{array}{l}\text { Regional } \\
\text { "Smarts", } \\
\text { Clusters } \\
\text { Hämeenlinna, } \\
\text { Forssa, } \\
\text { Riihimäki }\end{array}$ & $\begin{array}{l}\text { Multiple } \\
\text { qualitative } \\
\text { case study, }\end{array}$ & $\begin{array}{l}\text { Key element to } \\
\text { design the } \\
\text { "roadmap" for } \\
\text { Industry } 4.0\end{array}$ \\
\hline $\mathrm{E}$ & $\begin{array}{l}\text { Regional development } \\
\text { in modern robotic } \\
\text { education in industrial } \\
\text { and societal context }\end{array}$ & $\begin{array}{l}\text { How to support } \\
\text { local town's } \\
\text { strategy } \\
\text { (robotization) }\end{array}$ & $\begin{array}{l}\text { Cooperation } \\
\text { of local } \\
\text { education } \\
\text { institutes }\end{array}$ & $\begin{array}{l}\text { The strategy of } \\
\text { local town, } \\
\text { Riihimäki }\end{array}$ & $\begin{array}{l}\text { Multiple } \\
\text { qualitative } \\
\text { case study }\end{array}$ & $\begin{array}{l}\text { Robotic } \\
\text { education for all } \\
\text { to support the } \\
\text { change }\end{array}$ \\
\hline $\mathrm{F}$ & $\begin{array}{l}\text { Mobility as a service in } \\
\text { small cities }\end{array}$ & $\begin{array}{l}\text { Interaction of } \\
\text { different } \\
\text { ecosystems for } \\
\text { change to } \\
\text { improve service }\end{array}$ & $\begin{array}{l}\text { Digital } \\
\text { ecosystems }\end{array}$ & $\begin{array}{l}\text { Hämeenlinnato } \\
\text { wn mobility } \\
\text { development }\end{array}$ & $\begin{array}{l}\text { Multiple } \\
\text { qualitative } \\
\text { case study } \\
4.0\end{array}$ & $\begin{array}{l}\text { The importance } \\
\text { of digital } \\
\text { ecosystems for } \\
\text { service } \\
\text { development }\end{array}$ \\
\hline $\mathrm{G}$ & $\begin{array}{l}\text { Ecosystem of } \\
\text { ecosystems in inter- } \\
\text { city biking }\end{array}$ & $\begin{array}{l}\text { How to build } \\
\text { intercity service } \\
\text { system }\end{array}$ & $\begin{array}{l}\text { Digital } \\
\text { ecosystem }\end{array}$ & $\begin{array}{l}\text { Finnish } \\
\text { Growth } \\
\text { Corridor }\end{array}$ & $\begin{array}{l}\text { Multiple } \\
\text { qualitative } \\
\text { case study }\end{array}$ & $\begin{array}{l}\text { Connect } \\
\text { different digital } \\
\text { ecosystems to } \\
\text { support city } \\
\text { bike service. }\end{array}$ \\
\hline $\mathrm{H}$ & $\begin{array}{l}5 G \text { as a driver for } \\
\text { transition of } \\
\text { digitalization in } \\
\text { ecosystem-based } \\
\text { development }\end{array}$ & $\begin{array}{l}\text { How new } \\
\text { technology is } \\
\text { reacting on } \\
\text { various } \\
\text { ecosystem layers? }\end{array}$ & $\begin{array}{l}\text { Interaction of } \\
\text { various } \\
\text { ecosystem } \\
\text { layers in the } \\
\text { change }\end{array}$ & $\begin{array}{l}\text { Implementation } \\
\text { of new } \\
\text { technology }\end{array}$ & $\begin{array}{l}\text { Multiple } \\
\text { qualitative } \\
\text { case study }\end{array}$ & $\begin{array}{l}\text { Connect } \\
\text { different } \\
\text { ecosystem } \\
\text { layers to smart } \\
\text { city } \\
\text { development }\end{array}$ \\
\hline
\end{tabular}




\section{Publication A. Towards Smart City Concept in Small Cities}

Authors: Heikki Ruohomaa, Vesa Salminen and Iivari Kunttu

TIM Review, September 2019, Volume 5 ( https://timreview.ca/article/1264)

"This paper presents three cases of smart city development in small cities in Finland, each concentrating on a different aspect of smart city development. The cases reveal how a relatively small-sized city may take remarkable steps in smart city development by selecting a specific theme on which to build smart city activities. These examples also emphasize the critical role of public sector actors, showing that the public sector has a key role in creating the foundations for fruitful ecosystem-based development work.

However, the transition towards smarter cities involves not only technological development but also the changing and evolving roles of citizens, service providers and city authorities. In this transition, the key issue is creating and growing roles of collaboration, participation and coordination. Whereas mainstream research focuses on smart city transformation in big cities, aspects of this transformation in the context of small cities has been a widely neglected topic"

\section{Publication B. Renewing a University to Support the Adaptation of Industry 4.0 within a Region}

Ruohomaa Heikki, Mäntyneva, Mikko, Salminen Vesa.

Publisher IntechOpen ISBN: 978-953-51-3842-6, DOI:

10.5772/intechopen.69336

"The principal idea behind this article has been to combine the principles of Industry 4.0 to value network thinking and digitization. Industry 4.0 is about creating significant impact and opportunities where business, technology, services, and innovation intersect. The aim has been to find a transdisciplinary concept supporting higher education, regional development and business renewal in testing laboratories, while supporting and enabling new growth opportunities in the region".

"This requires combining various approaches. The main challenge is in the utilization of transdisciplinary knowledge and implementation work. The use of new technologies, including digitization and big data, can capitalize on new 
opportunities. According to the experiences of conceptual development work, successful activity in Industry 4.0 is dependent on systematic long-term development in the public sector. The essential topic is the preparation of up-todate platforms, which enables, controls, and supports the operations and creates a business environment to apply the approaches. There are several contributing technologies related to Industry 4.oframework. This implies that there is a major emphasis on competence development and shared learning to apply these technologies to support transdisciplinary regional development"

\section{Publication C. Ecosystem-based development on managing digital transformation}

Authors: Heikki Ruohomaa, Vesa Salminen

AHFE 2019, the Washington Hilton, Washington D.C. USA, July 24-28, 2019.

Publisher, Springer Nature, 2019, ISBN 3030201546, 9783030201548

"The main idea behind this article, was to understand the principles of industry 4.o framework and digitalization of the ecosystem-based development of value network thinking. The town has created vision, objectives and focus areas and is committed to long-term development based on the smart specialization strategy".

"In its ecosystem-based strategy the vision, the town has indicated its intension and provided guidelines to all stakeholders. It has invited all stakeholders to join common development work. To ensure the implementation of ecosystem-based development, the required effort will be made visible in all focus areas by having "a real life" environment pilot study and quick trials. Hämeenlinna town ecosystem development work has deepened the relationship with municipality, industry, the university and society as a whole."

"Education and re-education are reducing resistance to change, speeding the implementation, and supporting the positive attitude to change, by building versatile knowledge. When education takes place in a "real life" environment by pilots and quick trials, education is also fundamental for innovation. Hämeenlinna town itself is willing to be the "real life" environment and that way provide a platform for innovations and start-ups." 


\section{Publication D. Value Network Development in Industry 4.0 Environment}

Heikki Ruohomaa, and Jussi Kantola, Vesa Salminen, AFHE 2017, Florida)Publisher Publisher, Springer Nature, 2017 ISBN 3319603728, 9783319603728

"This article will demonstrate that 4.0 Industry is not only the goal but also the means. It introduces a strategic concept, responsible business leadership, for utilizing responsibility as a business and innovation driver to facilitate the transition of industrial business towards the new service economy. 4.o Industry is having a significant impact and creating opportunities where business, technology and innovation intersect”.

"The cooperation between government, enterprise and universities is essential to succeed in co-evolution when building up cumulative competence in the creation of solutions for regional development with the benefits of digitalization. It is also essential to have a common vision to direct the local operation and funding. Otherwise, the activities can splinter into pieces that do not form part of the whole vision.

The vision and approach are based on the needs of regional clusters and the strengths of the region (e.g., logistics, universities, natural resources). 4.0 Industry development will be seen as a smart utilization of digitalization, which has European level comparability to European development in all key clusters.”

"Education and training content will be designed to respond to future needs. Learning will take place in "real world" environments (field labs), which give a faster cycle time for the development and implementation of activities. This is the way to ensure the birth of new innovations and the renewal of the businesses and organizations.

Succeeding with 4.0 Industry co-innovation requires data-to-service management processes and the creation of an adaptive multidisciplinary cooperation model for solution development. For a research centre to be capable of collaborating with industrial companies, it is important to know the overall capability of the research and development unit." 


\title{
Publication E. Regional Development in Modern Robotic Education on Industrial and Society context
}

\author{
Ruohomaa Heikki, Salminen Vesa AHFE 2018, USA. Orlando 21-24 July 2018 \\ Publisher Springer Nature, 2018 ISBN 3319941968, 9783319941967
}

"In order to sustain a competitive advantage, cities and regions are expanding and renewing their strategies. By doing so, these leaders are expanding their value proposition multidimensional by concurrently creating strong potential through developing more competitive customer engaging environments, coinnovating sustainable services together with their partners, and collaborating to create integrated new sustainable business environments. Organizations today are facing increasing complexity to execute profitably on continuous digital business transition towards digitalization and robotization. “

"This article introduces the activities of Rïhimäki town and the surrounding society. These activities are aimed at smart specialization not only by using the town's strengths, but also by adapting new knowledge of digitalization and robotics to improve the overall competitiveness of business, society, education and town facilities."

"Industry 4.0 would be used as a transdisciplinary framework supporting the development of a local service ecosystem. Since Industry 4.0 is a European concept and part of a European platform, it is wise that best practices are benchmarked into European approaches and experiences.

"Education is not only seen as building up versatile knowledge, but also reduces resistance to change, speeds up the implementation, and supports the positive attitude to robotics. Education is also fundamental for innovation when it takes place in "real life" environments by pilots and quick trials."

"According to the experiences of the conceptual development work, a successful activity in Industry 4.0 is dependent on systematic long-term development in the public sector. The essential topic is to prepare up-to-date platforms which provide control, support the operation and create a business environment to apply new opportunities “ 


\section{Publication F. Mobility as a service in smart cities - new concept for smart mobility in Industry 4.0 framework}

Authors: Heikki Ruohomaa, Vesa Salminen

ISPIM2018 Innovation for Local and Global Impact, 7-10 April, Ottawa Canada

Publisher ISPIM, ISSN 2243-3376 - Number in the series: 91 - Electronic publication: ISBN 978-952-335-350-3. The publication is available to ISPIM members at www.ispim.org.

"The main idea behind this article was to understand how the principles of Industry 4.0 framework and digitalization affects the ecosystem-based development of value network thinking. The town has created vision, objectives and focus areas, committed to long-term development based on the smart specialization strategy."

"In its ecosystem-based strategy, the town has indicated the vision, intension and guidelines to all stakeholders. It has invited all stakeholders to be involved in common development work. To ensure the implementation of ecosystem-based development, the required effort will be made visible in all focus areas by having "real life" environment pilots and quick trials. Hämeenlinna town ecosystem development work has deepened the relationship with the municipality, industry, the university and the whole of society."

"Education and re-education are reducing resistance to change, speeding up the implementation and supporting the positive attitude to change by building versatile knowledge. When education takes place in a "real life" environment by pilots and quick trials, education is also fundamental to innovation. Hämeenlinna town itself is willing to be the "real life" environment and in this way provide a platform for innovations and start-ups."

\section{Publication G. Ecosystem of Ecosystems in Intercity Biking}

Authors: Heikki Ruohomaa, Vesa Salminen

AHFE2020 the San Diego July 16-21, 2020

Publisher Springer, Cham, 2020, Print ISBN 978-3-030-50790-9 Online ISBN 978-3-030-50791-6 
"The main idea behind this article was to understand the effect of digitalization on the ecosystem-based development thinking in the intercity framework. Towns are building their own networks to become involved in developing new operations. While cities largely receive their own funding as taxes, development and change management must be considered in the same way as in businesses. A key measure of efficiency is the improved service and achieved cost efficiency. The town has created service activities (biking) which are supported by other local activities and ecosystems. Some services should or might be useful if they are connected to ecosystems of other cities in order to be able to create new and required services. This would mean cooperation at the business ecosystem level, but also at the digital ecosystem level."

As a case study, this article examines the intercity biking ecosystem development on the Finnish Growth Corridor.

\section{Publication H. $5 \mathrm{G}$ as a driver for transformation of digitalization in ecosystem-based development}

Authors: Heikki Ruohomaa, Vesa Salminen

AHFE2O20 the San Diego, July 16-21, 2020

Publisher Springer, Cham, 2020, Print ISBN 978-3-030-50790-9 Online ISBN 978-3-030-50791-6

"The harmonization of data and standardization of new technologies will provide possibilities for developing new digital ecosystems. It will introduce new possibilities for innovation and business models when benefitting from the use of $5 G$. It is important to see the development action of $5 G$ on different interacting ecosystem layers."

"Since the speed of digital transition is fast and new technologies are continuously developing, it is important to have a clear vision and direction for development. There is neither clear understanding about the outcome nor the new business models which will develop in future.

"Since the new technologies have a strong focus on inter-compatibility, it is essential that there is ecosystem-based development. It will make complex and fast changing world development activities possible. It is also essential to have "real life" testing, piloting and learning environments." 
24 Acta Wasaensia

"Industry 4.o technologies are developing, but they are not yet completely ready. So old technologies will be used for a long time. Change will not happen "overnight", even if the change is fast. Many of the new technologies are already working reasonably well with $4 G$ connection. These technologies should be actively studied.” 


\section{THEORETICAL BACKGROUND}

The $4^{\text {th }}$ industrial revolution is a change that we have not faced before. It will provide challenges but also new opportunities for any business and society. In the research, on transition of the 4 th industrial revolution (4IR), ecosystem-based development and Industry 4.0 will bring the framework for the change to the business environment.

It will be difficult to predict all the forms of complex and fast change. The study framework is presented in Figure 5. It shows how various theories (ecosystem, innovation and smart specialization strategy) are supporting ecosystem-based development in the transition of $4^{\text {th }}$ industrial revolution and how Industry 4.0 is providing the framework for development.

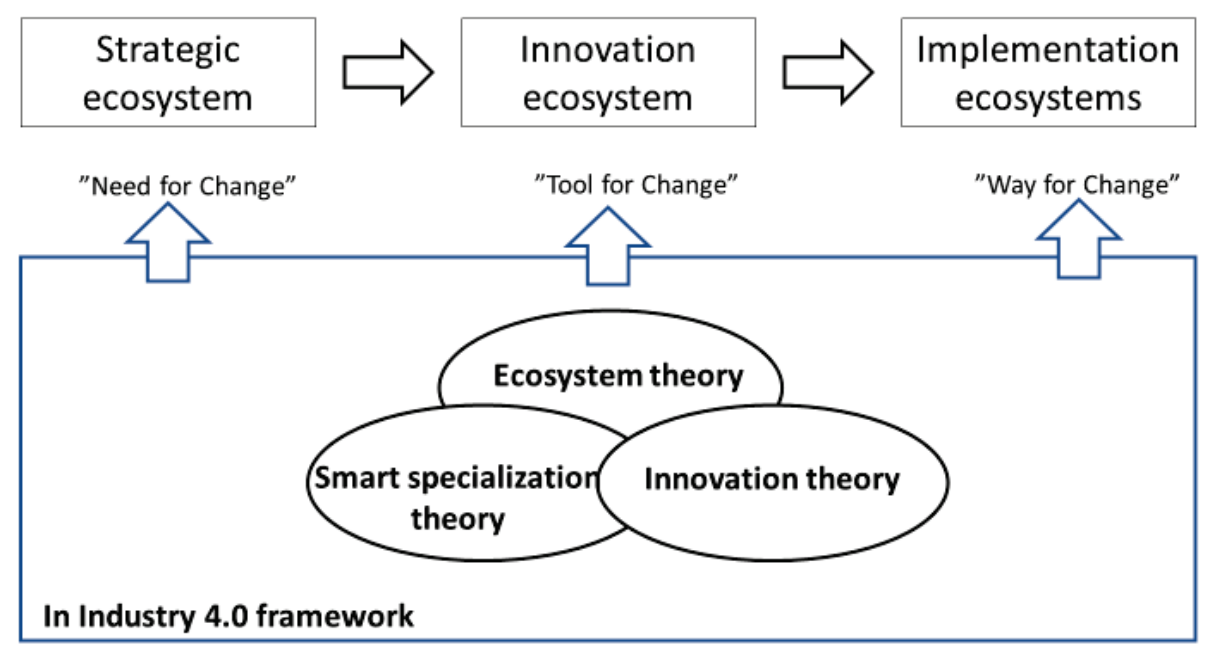

Figure 5. Steps of ecosystem-based development process.

The model of the ecosystem-based development process is based on three main theories (innovation, ecosystem and smart specialization strategy) in the Industry 4.o framework. The ecosystem-based innovation process is divided into three main stages: strategic ecosystem, innovation ecosystem and implementation ecosystem. Below, the reciprocal are rationalized in detail based on the empirical observations from the above publications. 


\subsection{Ecosystems}

Digitalization, "the sociotechnical process of applying digitizing techniques to broader social and institutional contexts that render digital technologies infrastructural" (Tilson et al., 2010), has unleashed new opportunities to inform, organize or interact and create the world of growing interdependence.

"The business ecosystem produces goods and services of value to customers, who are themselves members of the ecosystem" (Moore, James F., 1996). Dramatic changes in organizations' business ecosystems occurs, because digital business make them, more complex, larger and essential to strategy (Burton Besty, 2017).

\section{Business Ecosystems}

The metaphoric concept of the "business ecosystem" was introduced in 1993 by James F. Moore. (Moore, J., 1993). As far as the enterprises of each business ecosystem are concerned, the majority is composed of Small and Medium size businesses (SMEs) along with a few large companies, the so-called keystones. The role of these keystone companies to those of keystone species in nature, was compared by Marco Iansiti and Roy Levin (Iansisiti, M. and Levien R., 2004).

To represent the nature of a business ecosystem, Jeff Alex (2013) uses the metaphor of a biological ecosystem. Evolving with organic, diverse and symbiotic attributes is a key characteristic of an ecosystem. Through collaboration entities can be delivered something which is unattainable on one's own.

These business ecosystems are dynamic networks of entities to create and exchange sustainable value for participants by interacting with each other. Every organization exists in multiple business ecosystems. How the organization will survive and thrive in its ecosystem, is the challenge (Kasey, Panetta, 2017).

Ecosystems are also complex adaptive systems. In Knowledge Driven Entrepreneurship, Andersson, Curley and Formica (2003) define a business ecosystem as a network or coalition of resources, competencies, potential, energy, commitments, and promises to realize a shared profitable future. Geographical or virtual ecosystems can span or traverse a number of business ecosystems.

The first digital ecosystem lead was suggested in the European Commission by Nachira, in 2002. This important proposition paper has been finalized in a new framework (Nachira, F., 2002), called Digital Business Ecosystems: 
"The synthesis of the concept of Digital Business Ecosystems emerged in 2002 by adding 'digital' in front of Moore's (1996) "business ecosystem" in the Unit ICT for business of Directorate General Information Society of the European Commission."

The business e is considered, in this conceptual framework, as "An economic community supported by a foundation of interaction organisation and individuals - the organisms of business world" (Nachira, F. et al., 2007).

One of the brightest descriptions of an ecosystem in this term can be found in Chang and West's approach:

"There are four essences of ecosystems: (1) Interaction and engagement (2) Balance (3) Domain clustered and loosely coupled (4) Self-organisation” (Chang, E. et al., 2006).

\section{Digital Business Ecosystems}

"The business ecosystems metaphoric framework tries to formalize the business world into a practical complex model. While the crucial role of keystones in this definition can be considered as a downside for an economic ecosystem. Digital business ecosystems try to solve the problem in the digital world." (Razavi, R., et al., 2010). Jacobides (2019) defines digital ecosystems as "interacting organisations that are digitally connected and enabled by modularity and are not managed by a hierarchical authority”. Valdes-De-Leon Oman (2019) proposes a definition of digital ecosystems as "loose networks of interacting organisation that are digitally connected and enabled by modularity, and that affect and are affected by each other's offerings".

There are many interlinked ecosystems, or an "ecosystem of ecosystems" (Valdezde-Leon, 2017). This means that every entrepreneur and business organisation need to have a better knowhow, how to build up digital ecosystems. Ecosystem leaders need to be able to create the right incentives (financial and other kinds), as well as systems to support participants. They must decide how their ecosystem, and not competing ecosystems, will create more value for users and ecosystem participants (Valdez-de-Leon, 2015). Research by McKinsey estimates, that companies with an ecosystem approach have higher earnings than those without (Bughin et al., 2019).

It is risk, for a company not having an ecosystems strategy or taking part in digital ecosystems. As ecosystems become deeply rooted and conquer more of the 
available markets, those companies outside may find it hard to compete (Gawer, 2009a).

Participation in an ecosystem is "based not on the network's current scale, but rather on the number of users with whom they expect to be able to interact in the future" (Eisenmann, et al., 2007). It is essential to further grow market expectation to have an initial set of partnerships in support of the ecosystem (Valdez-de-Leon, 2015). New market entry may happen rather through a whole ecosystem that leverages its existing market power, technology and reputation to move into a market, not through individual innovators, (Gawer and Cusumano, 2008).

It can be a more strategic decision, in order to keep pace with the degree of innovation enabled by digital technologies and the rapid change of entire industries (Gawer, 2009b; Gawer and Cusumano, 2014; Van Alstyne et al., 2016).

The exponential growth of IoT connections indicates the birth of new business models and new kind of business environments (Deloitte, 2015). To attempt to connect everything (e.g. IoT, services, data, and people) requires radical redesigns within organizations. This is where the "explosion" of platforms is happening. Presently Industry 4.0 is more industrial-driven, but this will change and broaden (PwC 2016).

\subsection{Innovations}

The innovation, as a concept, is directly connected to the exploration of successful ideas that can create useful products, processes, services or valuable business practices (Schumpeter, 1982; Tether, 2003; Tidd, Bessant, and Pavitt, 2008). Innovation is by nature a complex process, that is to say, a process that comprises a large number of variables of various different kinds. Variables involve not only the natural laws and measurable dimensions (Kline and Rosenberg, 1986), but also abstract or intangible variables such as a low maturity of various technologies and their inter-relationships, managerial characteristics, the relationships between the areas involved in the innovation process, and even areas inside and outside the organization not directly involved in the innovation process.

All products and companies are subject to waves of innovation, for example, when a product changes significantly from its previous version driven by technological advances (Utterback, 1996). These interruptions generate the demand for companies to find innovations that make possible competitive leaps (Tushman and O’Reilly, 1996) and forces organizations to renew their processes and products, as well as the impact of technology in their field of business (Utterback, 1996). 


\section{Disruptive Innovations}

Disruptive innovations cause paradigm shifts and establish new trajectories of technological improvement (e.g., Bower and Christensen, 1995; Christensen, 1997). Through a series of improvements, the disruptive innovation attains the necessary performance levels valued by the mainstream market and offers a competitive solution to that of the incumbent technology (Dedehayir et al., 2017).

Miller and Langdon (1999) introduce ways to manage disruptive innovation by managing platform, product and process innovation in continuous cycles. It is important to see the world as a complex system and it must be understood that it is impossible to change one thing alone as everything is connected to something else (Sterman, J., 2000).

The disruptive innovation is highly competitive among mainstream customers because it carries the value proposition that has been central in its initial nurturing market. (Dedehayir, O. et al., 2017).

\section{Innovation Ecosystems}

Innovation ecosystems as complex adaptive systems have managerial implications. The ecosystem, as a concept, is biological and in ordinally means "an interactive system established between living creatures and their environment in which they live" (Krause, Razavi, Moschoyiannis, and Marinos, 2009). The innovation ecosystem can be extensively determined as a set of organizations which produces a comprehensive, connected technological system (e.g., smart watches, personal computers, and online marketplaces) that creates value for customers (Teece, 2007; Agerfalk and Fitzgerald, 2008; Basole, 2009).

Commensurate with the biological origins of this metaphor, some scholars have emphasized the indispensability of the keystone (Iansiti and Levien, 2004) or "platform leader" (Cusumano and Gawer, 2002) that lies at the core of the innovation ecosystem. The keystone's role is to regulate the overall function of the ecosystem and as a consequence its actions influence the success of all other members. However, empirical descriptions of innovation ecosystems often identify the importance not only of collaborating, but also of competing actors (Hannah and Eisenhardt, 2018) and competing technologies and standards (Arthur, 1989). 
The move to innovation ecosystems from the concept of business ecosystems might have overly shifted the focus to collaboration from competition (Granstranda O. and Holgerssonb M., 2020)

Innovation ecosystems can be called smart systems because of their openness, interaction with the environment, self-organization and emergence, adaptability, tolerance of mistakes and flexibility (see Murthy and Krishnamurthy, 2003). In such cases, the smart development of innovation ecosystems should be analysed from the viewpoint of complexity theory.

\section{Triple Helix (model of innovation)}

The evolutionary triple helix model was developed by Etzkowitz and Leydesdorff (1995). Triple Helix model represent different characters and degrees of cooperation between the three main actors involved in innovation: governments, universities and industry.

The theory on "systems of innovation" is strongly ruled by the institutional list approaches with focus on the structural aspects of the innovation systems (e.g., "triple helix" of government-academia-industry, infrastructure, policy and political environment) (Jucevicius G. and Grumadaite K., 2014).

The theory of "open innovations" can be collated with the triple helix as it try to find added value in taking industrial innovation closer to public R\&D. Whereas the firm is central in the model of open innovation, the triple helix adds multicentredness: in addition to firms and universities, regional government can take leading roles in innovation ecosystems (Loet Leydesdorff and Inga Ivanova, b2016).

The triple helix model of innovation has attracted considerable attention in both developed and developing economies as an integral policy-making tool to enhance innovation and promote economic development (Etzkowitz and Leydesdorff, 1997).

\subsection{Smart Specialization Strategy}

The concept of Smart specialization strategy was first introduced in a policy brief prepared for the Knowledge for Growth Expert Group to the European Commissioner for Research and Innovation, by Foray and Van Ark in 2007, (Foray and Van Ark, 2007), 
"Smart specialization is an innovation policy concept that aims to boost regional innovation, contributing to growth and prosperity by helping and enabling regions to focus on their strengths. Smart specialization is based on partnerships between businesses, public entities and knowledge institutions." (Marie Curin Accossiation 2018)

Smart specialization strategies encourage to the Europe 2020 goals of smart, sustainable and extensive growth by improving EU national and regional potential in innovation and research. Smart specialization strategy definition was established by the Regulation (EU) N 1303/2013 of the European Parliament and of the Council:

'Smart specialization strategy' means the national or regional innovation strategies which set priorities in order to build competitive advantage by developing and matching research and innovation own strengths to business needs in order to address emerging opportunities and market developments in a coherent manner, while avoiding duplication and fragmentation of efforts; a smart specialization strategy may take the form of, or be included in, a national or regional research and innovation (R\&I) strategic policy framework.

The smart specialization platform (S3 Platform) provides information, methodologies, expertise and advice to national and regional policy makers, as well as promoting mutual learning and trans-national cooperation, and contributing to academic debates around the concept of smart specialization. (Marie Curin Accossiation 2018)

\subsection{Industry 4.0}

The brand "Industry 4.0" was figured out by the German government to characterize and crystallized a set of technological transition in manufacturing and sets out priorities of a consistent policy framework with the purpose of developing the global competitiveness of German industry (Tay, S.I. et al., 2018). The Industry 4.0 was introduced at the Hannover Fair, in 2011. The event was symbolizing the birth of a brand-new era of industrial revolution (Qin, Liu, and Grosvenor, 2016).

Industry 4.0 is being presented as an overall change of manufacturing process. by digitalization and automation of every level of an enterprise. Big international companies that use concepts of continuous improvement and have high standards for research and development will accept the concept of Industry 4.0 and make themselves even more competitive in the market (Marcos et al., 2017). 
Industry 4.0 has many definitions. Kagermann et al. (2013) see Industry 4.0 to boost the development of the manufacturing industry by utilizing the power of communications technology and innovative inventions. Schumacher, Erol and Sihn (2016) estimates that the boundaries between virtual reality and the real world are getting obscure and present an effect known as Cyber-Physical Production Systems (CPPS). Schwab (2016) argue out that Industry 4.0 is one of the most important concepts in the development of industry and the global economy. Mrugalska and Magdalena (2017) say that Industry 4.0 is a benefit to stay competitive in any industry.

Industry 4.0 describes a future scenario of industrial production that is characterized by the aspects of a new level of controlling, organizing and transforming the entire value chain (Tay, S.I. et al, 2018). Industry 4.0 is currently one of the most frequently discussed topics among practitioners and academics in the German-speaking area (Dais, 2014, p. 625; Drath and Horch, 2014, p. 56).

The fascination in Industry 4.0 is twofold. Firstly, for the first time an industrial revolution is predicted a priori, not observed ex post facto (Drath, 2014, p. 2). Secondly, the economic impact of this industrial revolution is supposed to increase operational effectiveness and create entirely new business models, services, and products (Kagermann et al., 2013, p. 16; Kagermann, 2014, p. 603; Kempf, 2014, p. 5).

Based on that vision, the "Plattform Industrie 4.0" developed further recommendations on how to implement the vision (Kagermann et al., 2013, p. 77). It understands Industry 4.0 as "a new level of value chain organization and management across the lifecycle of products" (Platform Industrie 4.0, 2014). An important component of Industry 4.0 is the fusion of the physical and the virtual world (Kagermann, 2014, p. 603). This fusion is made possible by Cyber Physical Systems (CPS). CPS are "integrations of computation and physical processes. Embedded computers and networks monitor and control the physical processes, usually with feedback loops where physical processes affect computations and vice versa" (Lee, 2008, p. 363).

"Industry 4.0 framework defines the context for digitalization and IoT in the industrial context. This "smart industry" framework contains the connectivity of devices for effective value chain management using sophisticated data collection as well as data-based optimization and analysis. Industry 4.0 also gives a detailed and solid framework to the development work related to smart cities.”(Lom, M., Pribyl O., Svitek, M., 2016). 


\subsection{Summary}

The model of ecosystem-based development processes is based on three main theories (innovation, ecosystem and smart specialization strategy) in the Industry 4.o framework. The ecosystem-based innovation process is divided into three main stages: strategic ecosystem, innovation ecosystem and implementation ecosystem.

It is clear that the chosen theories support an ecosystem-based approach even if the approaches are different. In addition, we can see that all the chosen theories are focusing on change in complex environments and highlight cooperation with different partners. The approach of the Industry 4.0 framework will renew industries by using new ICT- based technologies.

\section{Strategic Ecosystem}

In this dissertation, the "strategic ecosystem" interlinks key actors, that collaborate closely, based on their own long-term interests, strategies or duty towards the same goal. These are actors that are able to set long-term goals and allocate resources required for development. In the case described in this dissertation, these are actors such as towns, universities and companies in the region. In publication $\mathrm{B}$, we are able to see that these key actors are able to create a smart specialization strategy for the region and this way allocate resources for development. We can argue that these are the actors who will create triple helix cooperation. Etzkowitz (2003) argues that, if countries develop towards the hybrid situation, this will help all three actors to reach joint long-term strategic goals. Tamayo-Orbegozo et al. (2017, p. 1,365) determine the regional eco-innovation ecosystem as a dynamic system in which organizations impact and are impacted by the interplay of different forces.

\section{Innovation ecosystem}

In this dissertation "innovation ecosystem" is seen as an ecosystem which actively develops new innovation in order to support change. The innovation ecosystem is directing its activities according guidelines set by strategic ecosystems, which also allocate the resources for activities.

Publication $\mathrm{C}$ describes the framework for a local core innovation ecosystem (in digitalization). The HAMK Smart Research Unit is the core of innovation 


\section{Acta Wasaensia}

ecosystems. Its nature and profile is focused on regional development and applied research based on the legal tasks of universities of applied sciences. Innovation ecosystems, driven by the HAMK Smart Research Unit, base their actions on the smart specialization strategy, which allocates resources to the activities. The important actions for innovation ecosystems are to build cumulative knowledge and to actively interact with companies and other stakeholders.

Innovation ecosystems also focus on creating disruptive innovations which take place on the interface of different sectors or by using the new digital technologies.

\section{Implementation ecosystems}

In this dissertation the "implementation ecosystem" describes how the different ecosystems interact at the moment of change. It also shows how we can improve the performance of a business ecosystem or create new offerings or products, e.g., by developing digital ecosystems.

Jucevicius and Grumadaite (2014), argued that "the smart development of innovation ecosystems is based on a profound comprehension of the dynamics of representatives, relationships, forces and results, both within and between cultural, political and economic subsystems of the social system. The repair of problematic parts in this system should be done by adapting a particular mix of mechanisms and sub-mechanisms to manage complex adaptive systems."

There is many interlinked ecosystems, not just one single ecosystem, or an "ecosystem of ecosystems" (Valdezde-Leon, 2017). This means that every business organization and entrepreneur require to achieve a better knowhow of how to approach digital ecosystems.

\section{Ecosystem-based development process}

In this dissertation, research shows that ecosystem-based development is a powerful for a complex and fast-moving environment. It has also shown that different ecosystems need to interact to move towards a common goal. This dissertation also introduces the idea that ecosystem-based development has different stages in a continuous circular process (Figure 12). 


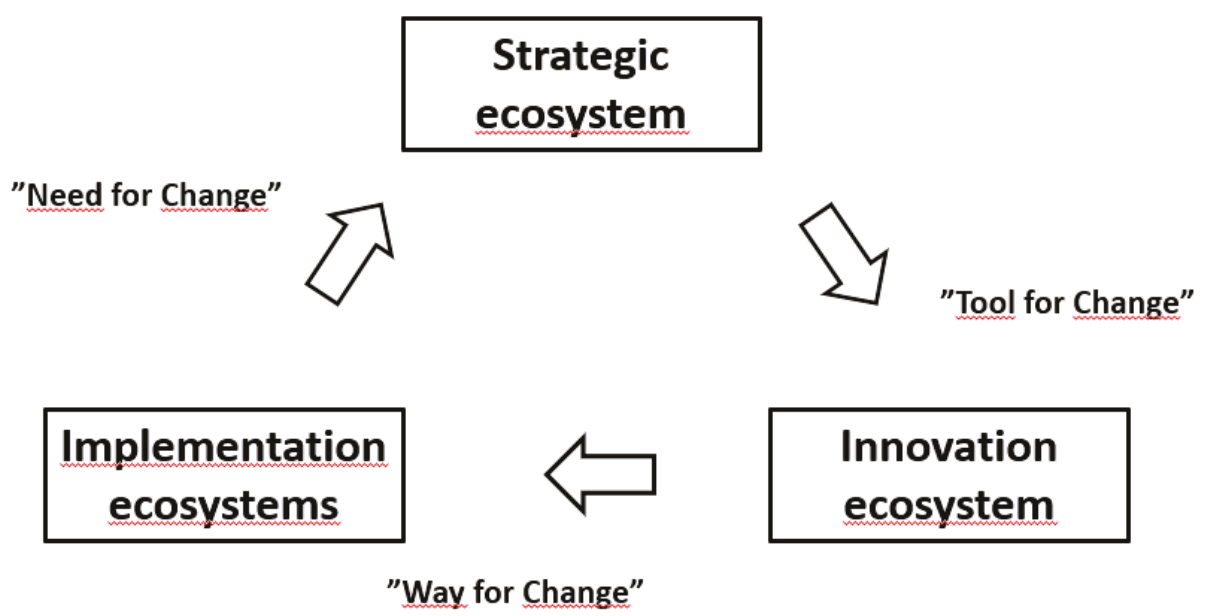

Figure 12. Continuous spiral ecosystem-based development process. 


\section{RESEARCH METHODOLOGY}

\section{"When the world changes then thinking has to change" Hans Jurgen Mittelstrass}

The transition of the 4th industrial revolution will be bigger than any other revolution during industrial time. Since the change will be complex and fast and have elements that we have no earlier experience, various assumptions and choices have been made regarding the work for this dissertation.

The nature of modern social reality set new challenges on futures studies in incessantly transforming and rather chaotic world. Sardar and Sweeney (2016) still question whether existing futures studies methods can cope with researching the contradictory uncertain and complex future.

One of the well know models for business studies developed by Saunders, Lewis and Thornhill (2016), the so-titled "research onion", is generally used to construct the theoretical research framework. Muranganwa (2016) remarks that the "research onion" concepts create a firm fundament for the development of consistent and acceptable research design. Raithatha (2017) also justify that on the basis of the "research onion" model, a suitable research methodology can be designed systematically, thus it can be used as the key academic research model. Although the research onion is an efficient model widely used in social sciences (works of Raithatha (2017), Ramdhani, Mnyamana and Karodia (2017) in marketing), it is also used in exact sciences.

The "research onion" presents a rather detailed description of the main layers or stages which are to be completed in order to design an effective methodology (Raithatha, 2017). The research methodology has its beginning with delineation of the main philosophy, selecting approaches, methods and strategies as well as cropping time horizons. Altogether, these take the research logic to the research design: main techniques and proceedings of data collection and analysis. (Aleksandras Melnikovas, 2018).

The formulation of this dissertation research is based on Saunders' onion framework, starting from a research philosophy and moving towards data collection. 
Table 2. Saunders' onion implemented in dissertation

\begin{tabular}{|l|l|l|l|}
\hline & What & Why & How \\
\hline A & Philosophy & $\begin{array}{l}\text { Need to understand the 4IR } \\
\text { transition and be prepared for } \\
\text { change. The goal is to have a } \\
\text { framework for supporting decision- } \\
\text { making. }\end{array}$ & $\begin{array}{l}\text { All means are possible to } \\
\text { carry out research. There is } \\
\text { no single right way to carry } \\
\text { out this kind of research. }\end{array}$ \\
\hline B & $\begin{array}{l}\text { Approach } \\
\text {-deductive }\end{array}$ & $\begin{array}{l}\text { Need to understand holistic view } \\
\text { from the elements of complex } \\
\text { change, which might give basis for } \\
\text { decision-making for practical } \\
\text { questions. }\end{array}$ & $\begin{array}{l}\text { Ecosystem-based } \\
\text { development approach was } \\
\text { chosen for research theory, } \\
\text { because it was expected to } \\
\text { be able to manage complex } \\
\text { change. }\end{array}$ \\
\hline C & $\begin{array}{l}\text { Strategy } \\
\text {-case study }\end{array}$ & $\begin{array}{l}\text { Need to have experience from "real } \\
\text { life" environments. }\end{array}$ & $\begin{array}{l}\text { Single cases or pilots, so that } \\
\text { the connections of different } \\
\text { actions and different } \\
\text { dependencies can be seen. }\end{array}$ \\
\hline D & $\begin{array}{l}\text { Choice } \\
\text {-mono } \\
\text { method } \\
\text {-qualitative }\end{array}$ & $\begin{array}{l}\text { Qualitive data was expected to give } \\
\text { a more accurate and holistic view. } \\
\text { Difficult to take quantitative } \\
\text { approach. }\end{array}$ & $\begin{array}{l}\text { Qualitative data collected } \\
\text { from different sources. }\end{array}$ \\
\hline E & $\begin{array}{l}\text { Time horizon } \\
- \text { cross } \\
\text { sectional }\end{array}$ & $\begin{array}{l}\text { Need to have experience of different } \\
\text { environments and different sectors } \\
\text { in order to see challenges. }\end{array}$ & $\begin{array}{l}\text { Separated case studies from } \\
\text { different fields. }\end{array}$ \\
\hline F & $\begin{array}{l}\text { Aim to find data for questions which } \\
\text { are not understood when asked. }\end{array}$ & $\begin{array}{l}\text { Data from literature, } \\
\text { workshops, interviews, } \\
\text { documents and pilots }\end{array}$ \\
collection & & \\
\hline
\end{tabular}

\subsection{Research Philosophy and Approach}

A research philosophy is a persuasion how data about a phenomenon should be collected, analysed and exploited. The term epistemology (what is known to be true) as opposed to doxology (what is believed to be true) includes the various philosophies of research approach (Galliers, 1991).

Pragmatism, as a research paradigm, is based on the proposition that researchers should use the philosophical and/or methodological approach that works best for the specific research problem that is being examined (Tashakkori and Teddlie, 1998). The pragmatic approach gives opportunity use any method, techniques and procedures, which suits best to the research problem. 
Honebein (1996) describes "the constructivism philosophical paradigm as an approach that asserts that people construct their own understanding and knowledge of the world through experiencing things and reflecting on those experiences." It is based on the analogy or basis that people form or construct much of what they learn through experience (Hein, 1991).

Exploratory research design can help in determining the research design, sampling methodology and data collection method (Singh, K., 2007). Exploratory research "tends to tackle new problems on which little or no previous research has been done" (Brown, R.B., 2006). Unstructured interviews are the most popular primary data collection method for exploratory studies.

At the paradigmatic level, this "study builds on constructivism, which aims to understand and reconstruct a studied reality. Constructivism assumes that reality is socially and experimentally constructed and includes multiple and even conflicting realities." (Guba and Lincoln, 1994).

To understand the transition of the $4^{\text {th }}$ industrial revolution, means understanding the fast and complex changes that will occur in the future. Since we have no prior experience of such a transition or its impact and consequences, pragmatism approach suits our research problem. On the other hand, we want to know, if ecosystem-based development would be a suitable tool to manage the $4^{\text {th }}$ industrial revolution transition and to build model accordingly. From that perspective our research philosophy is closer to constructivism.

The study follows the constructive research approach which may be seen as a type of applied science. The primary aim is to produce a proven problem solution, which works in principle, but whose actual practical suitability remains partly unclear. The qualitative research method is used to form the constructs. Case studies have been executed in Häme region of the Finnish Growth Corridor.

Publications, for this dissertation, were selected to demonstrate the studied interrelations and how they suplement each other.

Publication A describes smart city development in small cities in order to respond to future development and strategies.

Publication B was based on background work to renew regional smart specialization strategy. The theoretical framework for this work was the Industry 4.0 initiative. Research was based on a strong literature background and specialist interviews and observations. 
Publication $\mathrm{C}$ was based on implementing and creating an innovation ecosystem through ecosystem-based development at Hämeenlinna. The main data collection methods were observation, workshops, and interviews.

Publication D was based on a case study to renew education and integrate actions for regional development. A degree programme was designed to respond to future needs.

Publication E was based on a case study to build up strategic strength for the town, by building a robotic education ecosystem from nursery school to university in order to have the knowledge of robotics and to respond to the transition of technology.

Publication F was based on the case study of a city bike fleet and the digital and business ecosystems around it. Data were collected by interviews, test result/data, and pilot studies.

Publication $\mathrm{G}$ was based on the development work for biking and creating digital ecosystem for biking on the growth corridor so that it integrates local biking digital ecosystems.

Publication $\mathrm{H}$ was based on the need to manage different ecosystems in order to implement technology and opportunities to develop new innovative digital business ecosystems. 
Table 3. Research choices

\begin{tabular}{|c|c|c|c|c|c|c|}
\hline & Publication title & Context & Focus & Interrelation & $\begin{array}{l}\text { Research } \\
\text { approach }\end{array}$ & $\begin{array}{l}\text { Level of } \\
\text { analysis }\end{array}$ \\
\hline A & $\begin{array}{l}\text { Towards smart } \\
\text { city concept in } \\
\text { small cities }\end{array}$ & $\begin{array}{l}\text { Towns or } \\
\text { region }\end{array}$ & $\begin{array}{l}\text { Smart } \\
\text { specialization } \\
\text { strategy in } \\
\text { region }\end{array}$ & $\begin{array}{l}\text { Strategies of } \\
\text { town }\end{array}$ & Case study & Region \\
\hline B & $\begin{array}{l}\text { Renewing a } \\
\text { university to } \\
\text { support smart } \\
\text { manufacturing in } \\
\text { region }\end{array}$ & $\begin{array}{l}\text { Regional } \\
\text { development }\end{array}$ & $\begin{array}{l}\text { To understand } \\
\text { the local } \\
\text { strengths for } \\
\text { smart } \\
\text { specialization } \\
\text { strategy }\end{array}$ & $\begin{array}{l}\text { University- } \\
\text { enterprise } \\
\text { cooperation, } \\
\text { transdisciplin- } \\
\text { ary approach }\end{array}$ & Workshops & Region \\
\hline $\mathrm{C}$ & $\begin{array}{l}\text { Ecosystem- } \\
\text { based } \\
\text { development in } \\
\text { managing digital } \\
\text { transformation }\end{array}$ & $\begin{array}{l}\text { Ecosystem- } \\
\text { based } \\
\text { development } \\
\text { at Hämeenl. }\end{array}$ & $\begin{array}{l}\text { Implementa- } \\
\text { tion of } \\
\text { ecosystem- } \\
\text { based } \\
\text { development }\end{array}$ & $\begin{array}{l}\text { Innovation } \\
\text { ecosystem } \\
\text { definition at } \\
\text { Hameenlinna }\end{array}$ & $\begin{array}{l}\text { Workshops, } \\
\text { observations }\end{array}$ & Town \\
\hline D & $\begin{array}{l}\text { Value network } \\
\text { development in } \\
\text { Industry } 4.0 \\
\text { environment }\end{array}$ & $\begin{array}{l}\text { Multidiscip- } \\
\text { linary and } \\
\text { cooperative } \\
\text { environment, } \\
\text { at Forssa } \\
\text { town }\end{array}$ & $\begin{array}{l}\text { How to make } \\
\text { an approach } \\
\text { towards } \\
\text { "Industry 4.0" }\end{array}$ & $\begin{array}{l}\text { "Smarts" focus } \\
\text { areas and } \\
\text { clusters in } \\
\text { region }\end{array}$ & $\begin{array}{l}\text { Workshop, } \\
\text { pilots }\end{array}$ & University \\
\hline $\mathrm{E}$ & $\begin{array}{l}\text { Regional } \\
\text { development in } \\
\text { modern robotic } \\
\text { education in } \\
\text { industrial and } \\
\text { society context }\end{array}$ & $\begin{array}{l}\text { Strategy of } \\
\text { Riihimäki } \\
\text { town }\end{array}$ & $\begin{array}{l}\text { Implementing } \\
\text { robotic } \\
\text { education } \\
\text { ecosystem }\end{array}$ & $\begin{array}{l}\text { Educators' } \\
\text { ecosystem } \\
\text { at Riihimaki }\end{array}$ & $\begin{array}{l}\text { Workshops, } \\
\text { pilots, } \\
\text { observations }\end{array}$ & $\begin{array}{l}\text { Local } \\
\text { educators } \\
\text { and stake- } \\
\text { holders }\end{array}$ \\
\hline $\mathrm{F}$ & $\begin{array}{l}\text { Mobility as a } \\
\text { service in small } \\
\text { cities }\end{array}$ & $\begin{array}{l}\text { Bicycle fleet } \\
\text { in } \\
\text { Hämeenlinna } \\
\text { town }\end{array}$ & $\begin{array}{l}\text { Transdisciplin- } \\
\text { ary approach }\end{array}$ & $\begin{array}{l}\text { Digital and } \\
\text { business } \\
\text { ecosystems in } \\
\text { bicycle fleet }\end{array}$ & $\begin{array}{l}\text { Pilot, } \\
\text { interviews, } \\
\text { analysis of } \\
\text { digital bike } \\
\text { data }\end{array}$ & $\begin{array}{l}\text { Town } \\
\text { mobility }\end{array}$ \\
\hline G & $\begin{array}{l}\text { Ecosystem of } \\
\text { ecosystems in } \\
\text { intercity biking }\end{array}$ & $\begin{array}{l}\text { Finnish } \\
\text { Growth } \\
\text { Corridor }\end{array}$ & $\begin{array}{l}\text { Digital and } \\
\text { business } \\
\text { ecosystems }\end{array}$ & $\begin{array}{l}\text { Interaction of } \\
\text { various digital } \\
\text { and business } \\
\text { ecosystems }\end{array}$ & $\begin{array}{l}\text { Experiment, } \\
\text { Interviews }\end{array}$ & $\begin{array}{l}\text { Finnish } \\
\text { Growth } \\
\text { Corridor }\end{array}$ \\
\hline $\mathrm{H}$ & $\begin{array}{l}5 \mathrm{G} \text { as a driver } \\
\text { for transition of } \\
\text { digitalization in } \\
\text { ecosystem- } \\
\text { based } \\
\text { development }\end{array}$ & $\begin{array}{l}\text { Interaction } \\
\text { of } \\
\text { ecosystems }\end{array}$ & $\begin{array}{l}\text { Digital } \\
\text { ecosystems } \\
\text { for new } \\
\text { technology }\end{array}$ & $\begin{array}{l}\text { Interaction of } \\
\text { various layers } \\
\text { of ecosystems }\end{array}$ & $\begin{array}{l}\text { Workshops, } \\
\text { experiments }\end{array}$ & $\begin{array}{l}\text { Aseman- } \\
\text { ranta and } \\
\text { Visamäki } \\
\text { suburbs }\end{array}$ \\
\hline
\end{tabular}




\subsection{Research strategy}

Presenting research strategies, Saunders et al. (2016) promotes experiment, survey, archival research, case study, ethnography, action research, grounded theory and narrative study to be the key strategies for research. However, research strategies in the futures studies can be distinguished to a certain extent different way (Aleksandras Melnikovas, 2018).

Eisenhardt (1989) says that case studies are:

"Particularly well suited to new research areas or research areas for which existing theory seems inadequate. This type of work is highly complementary to incremental theory building from normal science research. The former is useful in early stages of research on a topic or when a fresh perspective is needed, whilst the latter is useful in later stages of knowledge."(pp.548-549).

Case study research is also good for present-day incidents when the relevant behaviour cannot be manipulated. Typically, case study research uses data from various sources, such as documents, artefacts, interviews and observation. This goes upwards of the range of sources of data that might be available in historical study (Rowley, J., 2002).

Case study research is useful when (Yin 1994):

"A how or why question is being asked about a contemporary set of events over which the investigator has little or no control" (Yin, 1994).

Yin (1994) defines a case study as:

“An empirical inquiry that:

- Investigates a contemporary phenomenon within its real-life context, especially when

- The boundaries between phenomenon and context are not clearly evident.”

Rowley (2002) highlight that an important strength of case studies is the power to undertake a study into a phenomenon in its context; in order to better understand the phenomena, thus it is not necessary to repeat the phenomenon in a laboratory or experimental setting (Rowley, J., 2002) 
This dissertation is based on the case studies/projects mentioned earlier. Industry 4.O was the pre-work for smart specialization strategy for Häme region. "Circular Economy business incubator" was part of the project related to Riihimäki town strategy implementation and development of industrial symbiosis. Robo Riksu was a project to create an education ecosystem to respond to the strategy of Riihimäki and support companies in their response to transitions in robotics. The Traffic 4.0 project has revealed how the city bike business needs a digital ecosystem round it and has shown the problems in building it. The $5 \mathrm{G}$ Start project has been given ideas to utilize new technology to renew city structure and city planning.

\subsection{Research choice and time horizon}

"Saunders et al. (2016) define research choice with reference to the use of quantitative and qualitative research methods, as well as the simple or complex mix of both, or the use of mono methods. Qualitative research methods involve numbers and mathematical operations, while qualitative methods imply the collection of a vast quantity of descriptive data. Mono method is used when the research is focused either on quantitative or qualitative data gathering; mixed methods - quantitative and qualitative methods is used within the same research in order to achieve different aims and offset the constraints of the use of a single method; multi-method choice undermines the use of both qualitative and quantitative methods, although the research is based on both of them; the other methods are auxiliary or supplementary" (Aleksandras Melnikovas, 2018).

"In the timeframe for the research, there are two options to choose from (Dissertation Writers 2020). Cross-sectional: this option presents a snapshot view of a particular situation at a single point in time and confines the duration of data collection and research to a short period of time. Longitudinal: this type of research studies events and behaviours using concentrated samples over a long period of time.” (Dissertation Writers 2020)

This dissertation is based mainly on the mono-method and qualitative data, but some case studies provide quantitative data to support the qualitative data. Each publication is based on a case study or case studies. Since a case study is a snapshot of particular project at single point in time, the research takes the cross-sectional option. This dissertation work was executed over the last four years and includes many cases studied at different times. By analysing the cases we are able to see that there is also a longitudinal option. 


\subsection{Data collection and analysis}

Case study approach can resemble mixed method research, since it can include various methods and data collection techniques. Qualitative methods were the main research tool, in this study, as shown in table 4 and table 5 . Since the data was collected from real business and business environment in various R\&D-cases, Data collection techniques was required to fit the circumstances of ongoing processes in real life. The main data collection techniques were interviews, workshops and pilots.

The researcher's role was to introduce a framework for each case study. Based on the requirement of each case, the researcher formulated the theoretical framework and facilitated the workshops, interviews/discussions at various stages of the process. The researcher was an active member in discussions, providing theoretical background and the legal limitation.

Table 4. Data description

\begin{tabular}{|c|c|c|c|c|c|}
\hline & Title & Period & Data & Analysis & $\begin{array}{l}\text { Role of the } \\
\text { researcher }\end{array}$ \\
\hline$A$ & $\begin{array}{l}\text { Towards smart city } \\
\text { concept in small cities }\end{array}$ & $\begin{array}{l}2018- \\
2019\end{array}$ & $\begin{array}{l}\text { Various } \\
\text { analysis, } \\
\text { workshops, } \\
\text { interviews }\end{array}$ & $\begin{array}{l}\text { Qualitative } \\
\text { content } \\
\text { analysis }\end{array}$ & Facilitator \\
\hline$B$ & $\begin{array}{l}\text { Renewing a university to } \\
\text { support smart } \\
\text { manufacturing in region }\end{array}$ & $\begin{array}{l}2016- \\
2017\end{array}$ & $\begin{array}{l}\text { Specialist } \\
\text { interviews, } \\
\text { literature }\end{array}$ & $\begin{array}{l}\text { Qualitative } \\
\text { content } \\
\text { analysis }\end{array}$ & $\begin{array}{l}\text { Observer / } \\
\text { facilitator }\end{array}$ \\
\hline $\mathrm{C}$ & $\begin{array}{l}\text { Ecosystem-based } \\
\text { development on managing } \\
\text { digital transformation }\end{array}$ & $\begin{array}{l}2018- \\
2019\end{array}$ & $\begin{array}{l}\text { Various } \\
\text { workshops } \\
\text { and interviews }\end{array}$ & $\begin{array}{l}\text { Qualitative } \\
\text { content } \\
\text { analysis }\end{array}$ & $\begin{array}{l}\text { Active } \\
\text { member in } \\
\text { process }\end{array}$ \\
\hline $\mathrm{D}$ & $\begin{array}{l}\text { Value network } \\
\text { development in Industry } \\
4.0 \text { environment }\end{array}$ & $\begin{array}{l}2017- \\
2018\end{array}$ & $\begin{array}{l}\text { Various } \\
\text { analysis, } \\
\text { workshops }\end{array}$ & $\begin{array}{l}\text { Qualitative } \\
\text { content } \\
\text { analysis }\end{array}$ & $\begin{array}{l}\text { Active } \\
\text { member in } \\
\text { process }\end{array}$ \\
\hline$E$ & $\begin{array}{l}\text { Regional development in } \\
\text { modern robotic } \\
\text { education on industrial } \\
\text { and society context }\end{array}$ & $\begin{array}{l}2018- \\
2020\end{array}$ & $\begin{array}{l}\text { Literature data } \\
\text { and interviews } \\
\text { and workshop }\end{array}$ & $\begin{array}{l}\text { Qualitative } \\
\text { content } \\
\text { analysis }\end{array}$ & $\begin{array}{l}\text { Designer of } \\
\text { the process }\end{array}$ \\
\hline $\mathrm{F}$ & $\begin{array}{l}\text { Mobility as a service in } \\
\text { small cities }\end{array}$ & $\begin{array}{l}2018- \\
2019\end{array}$ & $\begin{array}{l}\text { Data collected } \\
\text { from biking } \\
\text { fleet system } \\
\text { and by } \\
\text { interviews } \\
\text { from } \\
\text { customers }\end{array}$ & $\begin{array}{l}\text { Qualitative } \\
\text { content } \\
\text { analysis }\end{array}$ & $\begin{array}{l}\text { Active } \\
\text { management } \\
\text { of project }\end{array}$ \\
\hline $\mathrm{G}$ & $\begin{array}{l}\text { Ecosystem of ecosystems } \\
\text { in intercity biking }\end{array}$ & $\begin{array}{l}2019- \\
2020\end{array}$ & $\begin{array}{l}\text { Data collected } \\
\text { from biking }\end{array}$ & $\begin{array}{l}\text { Qualitative } \\
\text { content } \\
\text { analysis }\end{array}$ & $\begin{array}{l}\text { Designer } \\
\text { and active }\end{array}$ \\
\hline
\end{tabular}




\begin{tabular}{|l|l|l|l|l|l|}
\hline & & & $\begin{array}{l}\text { fleet and } \\
\text { interviews }\end{array}$ & & $\begin{array}{l}\text { member in } \\
\text { process }\end{array}$ \\
\hline $\mathrm{H}$ & $\begin{array}{l}\text { 5G as a driver for } \\
\text { transition of digitalization } \\
\text { in ecosystem-based } \\
\text { development }\end{array}$ & $\begin{array}{l}2019- \\
2020\end{array}$ & $\begin{array}{l}\text { Interviews } \\
\text { from 5G } \\
\text { suppliers and } \\
\text { potential } \\
\text { customers and } \\
\text { researchers }\end{array}$ & $\begin{array}{l}\text { Qualitative } \\
\text { content } \\
\text { analysis }\end{array}$ & $\begin{array}{l}\text { Designer } \\
\text { and active } \\
\text { member in } \\
\text { process }\end{array}$ \\
\hline
\end{tabular}

\section{Observation and participation}

According to Robson (2002), the advantage of observation is its directness. Therefore, it is considered an appropriate technique for studying real life in the real world. Observation revolves around two central elements: pre-structure, and the role of the observer. Restructuring means that observations can be informal or formal. Informal approaches are when the researcher collects information freely from informants and records it by taking notes. Formal approaches guide which information is gathered and observed, how observations are conducted and the observer only attends previously defined sessions. Formal observation yields higher reliability and validity, but it can lose the complexity and completeness found in the informal approach.

The role of the observer refers to the extent to which the observer participates in group activities. There are two observation extremes: to participate fully and become a part of the group or remain a pure observer with the aim to become as "wallpaper" (Robson, 2002, p. 314).

The present study (and the included publications) used observation and participation as methods of inquiry. Informal observation was applied and data documented. As such, the researcher's direct experience served as an important tool for inquiry.

\section{Interviews}

Interviews are a common data collection technique. In this study open interviews were used.

According to Firmin (2012), open interviews are suitable in five scenarios:

- Studying relatively new domains.

- The researcher can conduct research in waves or sequences, allowing the researcher to move towards more structured interviews.

- The primary goal is depth instead of breadth. 
- The study concerns ethnographic research involving a lot of shared time with individuals.

- The researcher works with articulate people who are given the freedom to contribute more to the studied subject than they would with structured methods.

In the case studies, observations and open interviews were the primary data collection methods.

\section{Analysis}

As is typical with research set in the real world, this study's data collection and analyses experienced some overlap, making them difficult to separate (Robson, 2002). This happened most noticeably in publications B and C.

The purpose of content analysis is to produce knowledge and insight, and to represent facts (Tuomi and Sarajärvi, 2002). According to Flick (2014), qualitative content analysis consists of many different forms, including discourse analysis and thematic analysis. Content analysis is usually carried out either inductively (categorization based on data) or deductively (categorization based on prior knowledge).

According to Miles and Hubermann (1994), the verification phase is critical to validity. The meanings drawn from the data must be tested for their confirmability, otherwise they are merely interesting stories. The principal vehicle of verification in these studies was interactivity, i.e., researchers and key informants discussed and reflected on the conclusions.

Finally, all the studies were peer-reviewed and presented at conferences or published in academic journals or books. 
Table 5. Principal phases of analysis

\begin{tabular}{|c|c|c|c|c|}
\hline & Publication title & Condensation & Display & $\begin{array}{l}\text { Drawing and } \\
\text { verifying }\end{array}$ \\
\hline $\mathrm{A}$ & $\begin{array}{l}\text { Towards smart city concept } \\
\text { in small cities }\end{array}$ & $\begin{array}{l}\text { How the smart } \\
\text { specialization } \\
\text { strategy is } \\
\text { supporting the } \\
\text { strategies of local } \\
\text { towns }\end{array}$ & $\begin{array}{l}\text { Implementation } \\
\text { of local } \\
\text { ecosystems }\end{array}$ & Pilots \\
\hline B & $\begin{array}{l}\text { Renewing a university to } \\
\text { support smart manufacturing } \\
\text { in the region }\end{array}$ & $\begin{array}{l}\text { Analysis on local } \\
\text { strengths and on } \\
\text { international } \\
\text { development - } \\
\text { interviews, } \\
\text { literature }\end{array}$ & $\begin{array}{l}\text { Key elements to } \\
\text { designing the local } \\
\text { service ecosystem } \\
\text { was created }\end{array}$ & $\begin{array}{l}\text { HAMK Smart } \\
\text { strategy }\end{array}$ \\
\hline $\mathrm{C}$ & $\begin{array}{l}\text { Value network development } \\
\text { in Industry } 4.0 \text { environment }\end{array}$ & $\begin{array}{l}\text { Analysis for } \\
\text { "Industry } 4.0 " \\
\text { framework for } \\
\text { development }\end{array}$ & $\begin{array}{l}\text { Curriculum for } \\
\text { Bioeconomy } \\
\text { (ITC) was created }\end{array}$ & $\begin{array}{l}\text { Bio } \\
\text { engineering } \\
\text { DP running }\end{array}$ \\
\hline $\mathrm{D}$ & $\begin{array}{l}\text { Ecosystem-based } \\
\text { development on managing } \\
\text { digital transformation }\end{array}$ & $\begin{array}{l}\text { Analysis regional } \\
\text { ecosystem-based } \\
\text { development }\end{array}$ & $\begin{array}{l}\text { "Smart innovation } \\
\text { ecosystem "- } \\
\text { portfolio }\end{array}$ & $\begin{array}{l}\text { HAMK Smart } \\
\text { ecosystem } \\
\text { portfolio }\end{array}$ \\
\hline $\mathrm{E}$ & $\begin{array}{l}\text { Regional development in } \\
\text { modern robotic education } \\
\text { on industrial and society } \\
\text { context }\end{array}$ & $\begin{array}{l}\text { Analysis to support } \\
\text { the industrial } \\
\text { strategy and region }\end{array}$ & $\begin{array}{l}\text { Robotic } \\
\text { education } \\
\text { and innovation } \\
\text { framework } \\
\text { (house of robotic } \\
\text { development) }\end{array}$ & $\begin{array}{l}\text { Robot } \\
\text { education and } \\
\text { development } \\
\text { activities }\end{array}$ \\
\hline $\mathrm{F}$ & $\begin{array}{l}\text { Mobility as a service in small } \\
\text { cities }\end{array}$ & $\begin{array}{l}\text { Analysis for digital } \\
\text { ecosystem to } \\
\text { support City bike } \\
\text { fleet }\end{array}$ & $\begin{array}{l}\text { Digital ecosystem } \\
\text { to support city } \\
\text { bike fleet service }\end{array}$ & $\begin{array}{l}\text { The pilot of } \\
\text { electric bicycle } \\
\text { digital } \\
\text { ecosystem }\end{array}$ \\
\hline G & $\begin{array}{l}\text { Ecosystem of ecosystems in } \\
\text { intercity biking }\end{array}$ & $\begin{array}{l}\text { Harmonization of } \\
\text { local and intercity } \\
\text { digital ecosystems } \\
\text { for services }\end{array}$ & $\begin{array}{l}\text { Growth Corridor } \\
\text { city bike } \\
\text { ecosystem }\end{array}$ & $\begin{array}{l}\text { Offer request } \\
\text { done }\end{array}$ \\
\hline $\mathrm{H}$ & $\begin{array}{l}5 G \text { as a driver for transition } \\
\text { of digitalization in } \\
\text { ecosystem-based } \\
\text { development }\end{array}$ & $\begin{array}{l}\text { Analysis to how to } \\
\text { use new } 5 \mathrm{G} \\
\text { technology }\end{array}$ & $\begin{array}{l}\text { Piloting } \\
\text { environment to } \\
\text { test } 5 G \\
\text { applications }\end{array}$ & $\begin{array}{l}\text { Piloting } \\
\text { environment } \\
\text { in use }\end{array}$ \\
\hline
\end{tabular}

\subsection{Summary of the research framework}

The aim of the research work is to understand the future transition of the fourth industrial revolution and be able to react to it, manage it and benefit from it. 
The speed and complexity of the fourth industrial revolution is unknown and there is no previous understanding of it. Pragmatism as a research philosophy for this dissertation is suitable and appropriate. However, since ecosystem-based development is considered to provide a reasonable basis for development, the approach is based more on constructivism. 


\section{REVIEW OF THE RESULTS}

To be able to respond to the complex and fast-moving change of the $4^{\text {th }}$ industrial revolution (4IR), an ecosystem-based development approach is utilized. It was needed to formulate the concept and methodology behind the ecosystem-based operation and development according to a holistic view.

There are many ecosystems around us and they are interacting and changing all the time. This leads to the following research propositions:

P1. Ecosystem-based change requires strong commitment and vision from all partners.

P2. Complex, fast-moving change needs transdisciplinary innovation, education and piloting environments.

P3. The reengineering of the business ecosystem and the changes on society require that all the ecosystems support the transition.

Evidence supporting the research propositions has been sought by addressing these research questions:

Q1. How can we prepare for change and develop a common vision of a strategy?

Q2. Does a smart specialization strategy provide the guidelines for allocating resources?

Q3. How can we integrate applied research for regional development?

Q4. How can education change to respond to the needs of the fourth industrial revolution?

Q5. How should digital ecosystems and data be structured?

Q6. How should the data be combined in ecosystems and different sectors?

The research questions were used to find evidence to support the research propositions. The main relationships between the research questions and propositions are:

- Proposition 1: Q1, Q2

- Proposition 2. Q3, Q4

- $\quad$ Proposition 3. Q5, Q6

The next section explains how the research project introduced earlier in this dissertation addresses each of the research questions. Arguments regarding the propositions have been found in research and development projects. They are 
analysed and reported in publications in the context of creating a suitable concept for an ecosystem-based framework.

\section{Q1. How can we prepare for change and develop a common vision of a strategy?}

Question 1 arises from the need to understand the nature and speed of 4IR transition and to understand the importance of the common vision of key stakeholders (Gov.-Univ-Comp), In order to be able to respond to the digital transition, we must create a long-term strategy together.

The importance of strategy building is illustrated by several case studies in publications A and B. During this dissertation work the strategy making (ecosystem-based) was recognized as the key issue to create common understanding supported by the mission of organization and the strengths of the region. Case studies show that the public sector (towns) has a key role in building fruitful ecosystem-based development at a strategic level.

Publication B also describes the S-curve, which shows the development from linear growth to exponential growth. It illustrates the complexity which is faced during change. The new Industry 4.0 technologies and the tipping points of these technologies have been predicted quite well using different sources to develop our understanding of the change. The challenge is to develop the vision and strategy to implement new technologies and reach a competitive edge.

The dissertation has also introduced the idea that building up an ecosystem is a long process requiring clear vision, strategy and scenarios. It needs a clear roadmap with systematic steps and an understanding of the heritage of the fundamental basis of an ecosystem.

\section{Q2. Does a smart specialization strategy provide the guidelines for allocating resources?}

Question 2 arises from the need to allocate the limited resources in the best possible way to respond to the change and to support the 4IR transition and strategies. There is the expectation that in the transition of 4IR that new Industry 4.o technologies will be created and new innovations will focus on areas of smart specialization. 
Publication B introduces the "Fishbone model for change" and the key elements for designing the local service ecosystem for Industry 4.0 based on smart specialization. The Industry 4.0 framework should be understood in the existing innovation environment such that smart clusters (ecosystems) can be established based on smart specialization strategy. International benchmarking could be applied to identify best practices.

During the dissertation, several problems related to Question 2. were identified:

- By using EU regional funding (ESR or EAKR) it is expected that development project funding is directed to the focus areas defined in the smart specialization strategy.

- Universities have the legal requirements to provide higher education, carry out applied research and support regional development.

- It is important that higher education and applied research activities run in parallel to the need of industries, the smart specialization strategy and the strategies of cities.

- The towns have planned their strategies based on the needs of the people, industry and local strengths.

- Education to support focus areas of smart specialization is important

Smart Specialization Strategy forces local actors on region to create common understanding about future goal and needed actions towards common goal in short and long run. That make possible efficient use of resources, but also longterm knowhow building and opportunity to readiness for change and make fundament for ecosystem-based change.

\section{Q3. How can we to integrate applied research into regional development?}

Question 3 arises from the need to understand the increasing demand of new innovations and to make the university part of the regional development towards 4IR transition.

In the case studies it is shown that the regional strategy is supported by smart specialization strategy and university education based on regional needs. By focusing key resources, knowledge and R\&D activities, an innovation ecosystem based on regional strengths is developed. Through this dissertation it has been recognized that it is important to understand the supporting nature of knowledgeintensive services in an increasingly digital world. 
Publication C demonstrates how applied research activities by UAS are organized to support regional development based on a smart specialization strategy. They combine to produce cumulative knowledge in order to support companies and society.

It is also shown how development activities by UAS have been linked according to the Industry 4.0 framework to ensure compatibility and credibility for development work. In the framework of the case study in publication D, HAMK Smart research activities can be seen as a central part of the innovation ecosystem.

When applied research takes place in a real life environment using pilots and quick trials, the region and towns could be real life environments and in this way provide a platform for innovations and start-ups.

It can be stated that transdisciplinary piloting and testing environment is needed in order to manage complex and fast change.

\section{Q4. How can education change to respond on the needs of the fourth industrial revolution?}

Question 4 examines the problem of changing the education system and building knowledge on the transition towards the $4^{\text {th }}$ industrial revolution. To answer this question, case studies are introduced in publications D and E. One of the key issues was to understand the complex and changing environment for education and develop education so that it is better able to respond to the change of $4 \mathrm{IR}$ and meet the requirements of companies.

The aim of publication $\mathrm{E}$ was to explore how different educator levels from nursery school to university level will be able to create an ecosystem that can support the strategy of a town on all educational levels.

Publication D describes how to structure the education programme so that the new 4IR technologies can be used to serve local industries and companies in innovative ways.

During the dissertation several issues related to Question 4 were identified:

- Applied research and education will take place in close cooperation with industry by "resolving real life" challenges in order to speed up the development in industry and the region and enable students to learn multidisciplinary skills. 
- The development activities are linked in according to the European Industry 4.0 framework to ensure European comparability and compatibility.

- Industry 4.0 can be seen as a platform that provides compatibility and thus the possibility to reap the benefits of best practices for regional development.

- By including stakeholders, we can reduce resistance to change and increase commitment and opportunities for new ideas and start-ups.

- Education is not only seen to build up versatile knowledge, but also to reduce resistance to change, accelerate implementation, and support the positive attitude towards new technology.

- Education is also fundamental for innovation when it takes place in a real life environment by using pilots and quick trials

Publication E introduces the "house of robotics" framework for implementation of new 4IR technologies. The implementation process in based on different layers.

To manage complex and fast change, there is need to develop education and education environments to response the needs of industrial revolution.

\section{Q5. How should digital ecosystems and data be structured? (How are digital ecosystems connected to other ecosystems?)}

Question 5 arises from the need to understand how the increasing amount of data should be collected, stored, opened, delivered, and harmonized, such that it supports the digital transition and develops new business and innovations.

Case studies and concept building are described in publications $\mathrm{F}$ and $\mathrm{H}$. The concept introduces the layers in smart city development for implementing the digital change. These layers create "the vertical ecosystem" framework, which is recognized to be essential for the implementation of digital transition.

Publication $\mathrm{H}$ also states that the harmonization of data and standardization of new technologies will make it possible to develop new digital ecosystems.

Throughout the dissertation, it has been reasoned that it is essential to understand the changes that must occur in business models when the amount of data is increasing and faster data processing is needed for decision-making. 
Data and ecosystems are linked to the re-engineering of business, since proper reengineering business need also proper implementation. The proper implementation can happen only via vertical ecosystems, because the reengineering of business requires infrastructure, digital ecosystems, innovation ecosystem (including proof of concepts) supporting each other towards change.

\section{Q6. How should the data be combined in ecosystems and different sectors?}

Question 6 arises from the need to understand how different sectors should be connected in order to utilize new 4IR possibilities to create new services and innovations at the interfaces of different sectors.

Publication $\mathrm{F}$ introduces a case study in the mobility sector regarding the development of a digital city bike system. The study shows that when testing a digital ecosystem in real life environments, issues arise which would not have been noticed in a laboratory environment. It has also introduced a model for ecosystembased innovation development using open data and quick pilots in real life environments. In this framework, the role of new innovations and the innovation process are very important.

Publication F shows that when a new and a present technology are brought onto the same platform, it is possible to see the problems in interoperability and to identify any standardization issues.

This research question connects proposition to the re-engineering of business, since new innovations take place usually in the interfaces of different sectors. So the different ecosystems of sectors should be able interact and create new innovations, which will be a fundament for the re-engineering of business and new business models. 


\section{DISCUSSION}

The aim of this research is to understand the elements of the $4^{\text {th }}$ industrial revolution (4IR), how we should prepare for transition, and how to build holistic understanding about the change to be managed.

The main driver of the 4IR change is new ICT-based technologies and an increasing amount of data. It is challenging for all sectors to apply the new technology for renewing business and making new practical innovations.

Ecosystem-based development is expected to be the most suitable way to respond to fast and complex change. Ecosystem-based development does not start just with an administrative decision. It brings clear benefits for all participants.

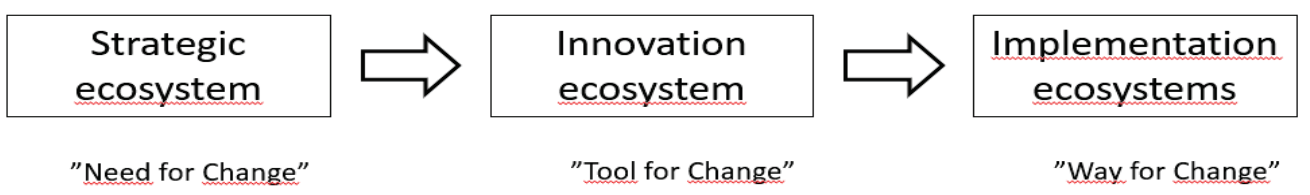

Figure 7. Ecosystem-based development process

\section{Strategic Ecosystem}

The need for a "strategic ecosystem" comes from the fact that there has to be a clear and justified vision of the direction of change and resources available for development.

The smart specialization strategy of a region is important because it gives direction on what will be developed in the region and also on long-term funding. Development of a smart specialization strategy is a long process which builds common understanding and vision for the region. During this process, the roles of different actors will become clearer and commitment to future actions will increase.

The members of the strategic ecosystem should build a fruitful business environment for change in various ways (e.g., towns could open the data sources, building the infrastructure such as fibre network, make regulation more motivating or just be a platform for new innovations).

It is also important that educators develop what they can offer to support local needs and activities in the transition. Towns and educators have huge purchasing 
power and in this way put pressure on suppliers to develop their activities to support innovation processes in the region (e.g., open data, harmonization of data). The actions of educators and towns should run in parallel.

We can see that the role of the strategic ecosystem is not only making a vision for the future and allocating resources, it also supports actors to improve the business environment in their daily decision-making.

\section{Innovation ecosystem}

Innovation ecosystems can be called smart systems because of their openness, interaction with the environment, self-organization and emergence, adaptability, tolerance of mistakes and flexibility (see Murthy and Krishnamurthy, 2003).

New ICT-based technology and the increase in data are the key drivers for the 4IR transition. New knowledge and innovations are needed before the new technologies are implemented in full and new business models are been introduced.

New technology provides new possibilities to collect, store, process and use data and thus provide new services for a larger number of people. New technologies make it possible to change data in real time and to have customer-driven innovations at the interfaces of various sectors or organizations. It is expected that most of the new inventions will take place at the interfaces of sectors such as the interface between healthcare information and mobility.

Digitalization makes it possible to re-design the whole value chain and create new services for customers. In this way old business models are disrupted. For this reason, an innovation ecosystem is able to create new knowledge and innovations which exists at the interfaces of various different sectors. Publications C and D describe how education is built to support regional strategy for transition of the fourth industrial revolution.

Since the innovation process is complex and fast, there is a need for a real-life innovation environment/platform to speed up the innovation process in real life ecosystems. These ecosystems have a common understanding about sharing data and ownership of data, but also on agreement of standardization and harmonization of data. 


\section{Implementation ecosystem}

The full-scale benefit from new technology and innovation comes when the new technologies have been widely implemented and new business models have been put in place.

Since the implementation process is extremely complex in the 4IR transition, it is wise to divide it into different levels/ecosystems in order to make it easier to develop. The successful implementation of transition is dependent on how the elements/ecosystem levels are able to interact.

Publication $\mathrm{H}$ introduces the "the vertical ecosystem" (fig.5) which connects different ecosystem on different level to support transition. It also introduces the importance of "infrastructure ecosystem" and "sustainable ecosystem" which give the rules for development (laws, rules, limitations, support, taxes, etc.) and in this way provide the direction for innovation and development.

Even if a single ecosystem layer works perfect, other ecosystems might have deficiencies, so the full-scale benefits of a new digital technology would not be achieved. This kind of problem might be a lack of standardization, limited availability of data, problems with infrastructure, old legislation, etc.

The issues mentioned above are mainly issues which are the responsibility of towns, regions or the government. Single companies do not have much impact. For a single company, the key issue is to be able to implement new technology to boost business. This is why a business ecosystem has to manage a process from idea to proof of concept (POC).

Publications $\mathrm{F}$ and $\mathrm{G}$ focus on a case study of city bike system in the Finnish Growth Corridor. One of the key findings was that in addition to the digital ecosystem in a single town, all towns on the Growth Corridor should build an intercity ecosystem to get the full benefit of digitalization.

\section{Ecosystem-based development process}

This dissertation describes the "ecosystem-based development process" as a concept to manage $4^{\text {th }}$ industrial revolution transition.

Ecosystem-based development has to be seen as a continues process, starting from the first step to create a common vision and commitment to action from all 
partners in the ecosystem, all the way to the moment when the change is implemented and is in use.

This dissertation work indicates the key elements for future change and how it should be managed. The following elements were considered to be critical: harmonization of data, piloting environments, availability of data, open data, data platforms and quick piloting. They are key issues in developing new innovations for managing transition of $4 \mathrm{IR}$.

Even if the elements mentioned above are essential for an implementation ecosystem, the rules for these elements should be set out in the strategic ecosystem.

Since towns are the key actors in strategic ecosystems, they could make decisions about data harmonization and availability of open data. Towns could also be real life piloting environments.

These actions could easily be carried out by region/towns since towns use taxpayers' money. Towns and municipalities purchase a lot of services and products. They could use their purchasing power to push suppliers towards open data for public use. In addition, towns could use their purchasing power to harmonize data and ensure interoperability.

Industry 4.0 would provide a suitable framework for development, but at this stage would give ideas rather than precise rules. $5 \mathrm{G}$ or any other ICT-based technologies do not provide full-scale benefits unless the questions related to availability of data have been solved.

\section{Summary}

In summary, the benefits of new technology depend on how the data is exploited, the key factors being data ownership, availability and standardization.

Doctoral student has formulated the research independently. Data has been collected in several different projects, which are managed by doctoral student. The concept of ecosystem-based development concept is introduced by doctoral student and validation has been done in several case studies and published in eight international peer reviewed publication. 


\section{Acta Wasaensia}

\section{THEORETICAL CONTRIBUTION}

The research areas of innovation ecosystems or digital ecosystems are not a new research areas, but to see ecosystems as "a tool" to manage the fast and complex change of $4^{\text {th }}$ industrial revolution (4IR) has not been the focus of many research studies. Therefore, this work makes a theoretical contribution. In addition, there is little in the literature about ecosystem-based development in developing business environments. There is a new research contribution regarding the importance of open data and real life piloting environments in the creation of innovation ecosystems or "proof of concept" creation to implement changes to business ecosystems.

This dissertation includes Industry 4.0 framework as part of a regional development process to give guidelines rather than to give rules.

The development of the digital ecosystem is carefully examined and tested using real life piloting environments and using open data in the complex transition.

One of the theoretical contributions of dissertation is that it provides guidelines for ecosystem-based development and the key elements for change. Which are:

a.) strong commitments and vision from all partners

b.) change needs a transdisciplinary, innovation education and piloting environment

c.) to re-engineer business all the ecosystems have to support the transition

The main contribution of this dissertation is to show the different steps in the strategy of ecosystem-based development, which can be seen as a "horizontal ecosystem-based development process". Another important contribution is, to highlight the importance of "vertical ecosystem integration" to ensure proper implementation of change in transition. 


\section{MANAGERIAL CONTRIBUTION}

In conclusion, the scientific managerial contributions of the present study are analysed. The validity, reliability, assessment, generalizability and limitations are discussed.

The scientific and managerial contribution of this study follows the constructive research theory and how the construction is tested. This is vital for the stakeholders applying the general model of ecosystem-based development. Finally, recommendations for future research are presented.

The focus area of this dissertation has been quite large. This enabled a holistic view of the different ecosystems and ecosystem-based development. A narrower study would have meant that that not all the aspect of ecosystem-based development could have been addressed. This work has provided insight into the beginning of the ecosystem-based process and what is needed to develop ecosystem-based development.

This work has also described the process for building an innovation ecosystem. It is based on regional development work based on smart specialization strategy by universities of applied sciences. An innovation ecosystem is aims to increase the cumulative knowledge and skills needed to develop industry and business life.

The material and experience for this dissertation has been collected over four years, combining many projects, case studies, observations and smaller development projects. The challenge of this dissertation was that there is no experience of how a change like the fourth industrial revolution will happen and how this revolution should be managed or researched.

The ecosystem-based development theory has been observed because ecosystembased development talks are "on the air", and because ecosystem-based development is expected to be the practical response to the fast and complex changes.

As well the practical contribution of dissertation is that it provides guidelines for ecosystem-based development and the key elements for change. Which are:

a.) strong commitments and vision with supplier and customer networks

b.) testing new products and services on "real life" environment will speed development and implementation.

c.) digital ecosystem integration is essential to renew business models.

Anyhow these elements should be applied in practice, based on current situation and business. 
60 Acta Wasaensia

This dissertation has also shown the Industry 4.0 framework to be a guideline for development in a time of new technologies and exponential growth in data, which will change business models and value chains. The Industry 4.0 framework provides the necessary architecture, standardization and compatibility to the European digital single market (DSM). 


\section{CONCLUSIONS}

The $4^{\text {th }}$ industrial revolution (4IR) will change societies, business and education. The change will be bigger than anything we have ever known.

The goal of this dissertation was to find the available parts of methodology and fine tune them to create new concepts to build a framework for ecosystem-based development in the transition of the $4^{\text {th }}$ industrial revolution (4IR). At the beginning of the dissertation three research propositions were set out and answers to these were sought according conceptual constructive research using six different interlinked questions. The propositions have been validated by case studies and post-case study validating discussions. These studies and discussions formed the qualitative research based on a constructive research approach. This framework has been drafted and validated by case studies.

The concept of ecosystem-based development in a complex and changing environment needs holistic thinking. One key issue, based on this study, is a strong common vision which is produced by ecosystem-based cooperation with stakeholders.

This concept links together the roles of different ecosystems so that complex and fast change can be managed in the best possible way. This dissertation justifies the role of different ecosystems at different stages of development and in different time horizons.

From the many results and experiences gathered during this dissertation, it appears that ecosystem-based development is a long journey, but will provide solutions for complex problems and situation.

\subsection{The limitations of the research}

The case studies were carried out on the Häme region Finnish Growth Corridor. There is a long tradition of cooperation between different key stakeholders (government municipality, companies and university of applied science (UAS)).

The research took place between 2016 and 2020, at the time when discussions about the impact of fourth industrial revolution began. This is also the time period when the HAMK Smart Research Unit prepared to respond to the legal task of UAS for regional development and applied research. 


\subsection{Suggestions for future research}

In this study, the ecosystem-based development has been discussed mainly from a strategic, innovation or digital ecosystem point of view. There is little discussion of human-related issues like organization culture or the role of human factors during this transition.

While writing this part about the dissertation, new $5 \mathrm{G}$ technology has started to take use and new $5 \mathrm{G}$ antennas is build in region, also Finland is preparing to fight againt Coronavirus. The universities have been closed and the teachers and students are forced to communicate over the internet. Many workers in companies are forced to stay at home and work from a distance. The government has issued new regulations and travelling over the border is forbidden. Restaurants can sell only take-away meals. In Spain around 1,00o people are dying each day from Coronavirus.

The Helsinki area has been isolated from the rest of Finland. We know that we are entering a health, social and economic crisis for months.

The communication technology which has existed for some years, is now being used on a large scale. All the analysis indicates that we are on the brink of new kind of ecosystem, from a human perspective. Now, it will be impossible to predict what the final outcome will be.

It is a justified argument to believe that the $4^{\text {th }}$ industrial revolution is moving from linear growth to exponential growth. $5 \mathrm{G}$ technologies are transmitting data efficiently and new technologies, which are entering on the market and arriving to our daily lives. Because of the Coronavirus epidemic, we will be even more enthusiastic about implementing new Industry 4.0 technologies and using new applications.

Interesting future research would be to look at the human factor in the ecosystembased development in the transition of fourth industrial revolution. A good viewpoint would be the Society 5.0 approach which is more human-oriented than Industry 4.0, which is more business oriented. Industry 4.0 and Society 5.0 approaches complete each other and form a powerful combination.

Important research would be also the $4^{\text {th }}$ industrial revolution changes in education, since it is predicted that even $70 \%$ of job description do not any more exit in year 2035, new technologies (e.g. virtual reality, artificial reality etc.) gives new way to delivery education globally as well artificial intelligence gives 
possibility design education based on individual skills and needs. Anyhow it is clear that educational landscape and markets will change rabidly. 


\section{References}

Agerfalk, P.J. and Fitzgerald, B. (2008), "Outsourcing to an unknown workforce: Exploring open sourcing as a global sourcing strategy", MIS Quarterly, Vol. 32 No. 2, pp. 385-409.

Andersson, T., Curley M., and Formica P. (2010), Knowledge-Driven Entrepreneurship: The Key to Social and Economic Transformation 2010: Springer.

Alex, J. (2013), "Creating a Culture of Innovation" Lecture at Georgetown University to the Communications, Culture \& Technology course on "Creating a Culture of Innovation" available on-line at http://www.slideshare.net/JeffAlex/why-innovation-ecosystems-lecture accessed Jan 2013. 2010.

Arthur, W. B. (1989), Competing technologies, increasing returns, and lock-in by historical events. Econ. J. 99 (394), 116-131.

Bower, J.L. and Christensen, C.M. (1995), "Disruptive technologies: Catching the wave.” Harvard Business Review, Vol. January-February, pp. 43-53.

Brown, R.B. (2006), "Doing Your Dissertation in Business and Management: The Reality of Research and Writing" Sage Publications, p.43

Chang, E. and West, M. (2006), "Digital Ecosystem-A next generation of the collaborative environment," The Eight International Conference on Information Integration and Web-Based Applications \& Services, books@ ocg. at, 2006, pp. $3-23$.

Cusumano, M.A. and Gawer. A. (2002), “The elements of platform leadership" MIT Sloan Management Review, Vol. Spring, pp. 51-58.

Dais (2014), Industrie 4.o - Anstoß, Vision, Vorgehen. In: Bauernhansl, T., M. ten

Hompel and B. Vogel-Heuser eds., 2014: Industrie 4. o in Produktion, Automatisierung und Logistik. Anwendung, Technologien und Migration, 625634.

Dedehayir Ozgur, Ortt Roland, Seppänen Marko (2017), Disruptive change and the reconfiguration of innovation ecosystems. J. Technol. Manag. Innov. 2017. Volume 12, Issue 3

Deloitte (2015) Industry 4.0 challenge: Challenges and solutions for the digital transformation and use of exponential technologies

Deloitte Review (Issue 20, 2017). The rise of mobility as a service.

Dissertation Writers (2020), Saunders' Research Onion - A Step-By-Step Guide To Structuring Research Methodology Chapter For PhD And Master-Level Researchers, https://www.ukdissertationwriters.com/saunders-research-onion- 
a-step-by-step-guide-to-structuring-research-methodology-chapter-for-phd-andmaster-level-researchers/

Drath, R. (2014), Industrie 4.0 - eine Einführung, 3, 2-7. Retrieved from http://www.openautomation.de/fileadmin/user_upload/Stories/Bilder/oa_201 4/oa_3/oa_3_14_ABB.pdf (2.12.2014).

Drath, R. and Horch, A. (2014), Industrie 4.0: Hit or Hype? [Industry Forum]. IEEE Industrial Electronics Magazine, 8(2), 56-58.

Eisenhardt, K.M. (1989), "Building theories from case study research. "Academy of Management Review", 14(4), pp.532-550.

Eisenmann, T., Parker, G., Van Alstyne, M. (2007), Platform Networks - Core Concepts. Executive Summary. The MIT Center for Digital Business. Paper 232. http://ebusiness.mit.edu/research/papers/232_VanA lstyne_NW_as_Platform.pdf. Last accessed: 10 May 2019).

Etzkowitz, H. and Leydesdorff, L. (1995), "The Triple Helix: university-industrygovernment relations. A laboratory for knowledge based economic development", EASST Review. European Society for the Study of Science and Technology, Vol. 14, No. 1, pp.18-36.

Etzkowitz, H. (2003), 'Innovation in innovation: the Triple Helix of universityindustry-government relation', Social Science Information, Vol. 42, No. 3, pp.293-338.

European parliament (2016), Study for ITRE Committee. 4.o Industry IP/A/ITRE/2015-02 ipol stud

Firmin, M. (2012), Unstructured Interview. In: Given, L. M. (ed). The SAGE encyclopaedia of qualitative research methods (Vols. 1-0). Thousand Oaks, CA: SAGE Publications Ltd.

Flick, U. (2014), An introduction to qualitative research. $5^{\text {th }}$ ed. London: Sage Publications.

Foray and Van Ark (2007), Smart specialisation in a truly integrated research area is the key to attracting more R\&D to Europe, Knowledge Economists Policy Brief, no. 7.

Galliers, D. Robert (1991), Choosing Appropriate Information System Approach: A revised Taxonomy. In Nissen, H-E., Klein, H.K. and Hirschheim, R. (Eds.). Information systems Research Contemporary Approach and Emergent Traditions, Amsterdam: North Holland, pp. 327-345.

Gawer, A. (2009a), Platforms, Markets and innovation: an Introduction, in Gawer, A. (ed.) Platforms, Markets and Innovation. Cheltenham: Edward Elgar.

Gawer, A. (2009b), Platform Dynamics and Strategies: From Products to Service', in A. Gawner (ed.) Platforms, Markets and Innovation. Cheltenham and Northampton, MA: Edward Elgar.,45-76. 
Gawer, A. (2014), Bridging Differing Perspectives on Technological Platforms: Toward an integrative framework, Research Policy, 43(7): 1239-1249.

Gawer, A. and Cusumano, M. A. (2014), Industry Platforms and Ecosystem Innovation. Journal of Product Innovation Management, 31(3): 417-433.

Granstranda Ove, Holgerssonb Marcus (2020), Innovation ecosystems: A conceptual review and a new definition Technovation 90-91 (2020) 102098.

Guba, E.G. and Lincoln, Y.S. (1994), Competing paradigms in qualitative research. Handbook of Qualitative Research, 2(163-194), pp.105.

Hannah, D.P. and Eisenhardt, K.M. (2018), How firms navigate cooperation and competition in nascent ecosystems. Strateg. Manag. J. 39 (12), 3163-3192. https://doi.org/10.1002/smj.2750.

Hein, G. E (1991) “Constructivist Learning Theory” CECA (International Committee of Museum Educators) Conference, Jerusalem Israel, 15-22 October 1991

Herman, M., Penteck, T., and Otto, B., Design Principles for Industry 4.0 Scenarios (2017): A literature Review, Business Engineering Institute St. Gallen, Lukasstr. 4, CH-9008 St. Gallen.

Honebein, P. C. (1996), Seven goals for the design of constructivist learning environments. In Wilson, Brent. G. (Ed.). (1996) Constructivist learning environments: case studies in instructional design. Educational Technology Publications. New Jersey: Englewood Cliffs.

Häme Regional Council (2020), https://www.hameenliitto.fi/elinvoima-jakehittaminen/kehittamisohjelmat/smart-tavastia/ 28th April 2020.

Iansiti M. and Levien R. (2004), The Keystone Advantage: What the New Dynamics of Business Ecosystems Mean for Strategy, Innovation, and Sustainability, Harvard Business School Press, 2004.

Iansiti, M. and Levien, R. (2004), "Strategy as ecology", Harvard Business Review, Vol. March, pp. 1-10.

Jacobides, M. (2019), Designing Digital Ecosystems. In Jacobides, M. et.al. (2019), Platforms and Ecosystems: Enabling the Digital Economy, Briefing Paper, World Economic Forum. Accessed May 12, 201: http://www3.wefo(rum.org/docs/WEF_Digital_Platfor ms_and_Ecosystems_2019.pdf

Jacobides, M., Cennamo, C., and Gawer, A. (2018), Towards a Theory of Ecosystems. Strategic Management Journal, 39(8): 2255-2276.

Jucevicius Giedrius, Grumadaite Kristina (2014), Smart development of innovation ecosystem, International Scientific Conference; Economics and Management 2014, ICEM 2014, 23-25 April 2014, Riga, Latvia.

IoT Community 2019, http://iotcommunity.com/the-program/ 
Kagermann, H., Wahlster, W., and Johannes, H. (2013), Recommendations for Implementing the Strategic Initiative INDUSTRIE 4.o. Forschungsunion, 2013.

Kagermann et al. (2013), Kagermann, H., W. Wahlster and J. Helbig, eds., 2013: Recommendations for implementing the strategic initiative Industrie 4.0: Final report of the Industrie 4.o Working Group.

Kagermann, H., (2014), Chancen von Industrie 4.0 nutzen. In: Bauernhansl, T., M. ten

Hompel and B. Vogel-Heuser, eds., (2014), Industrie 4.o in Produktion, Automatisierung und Logistik. Anwendung, Technologien und Migration, 603614 .

Kempf, D. (2014), Vorwort. In F. I. BITKOM, ed., Industrie 4.0 Volkswirtschaftliches Potenzial für Deutschland, 5 .

Klin, S. J. and Rosenberg, N. (1986), An overview of innovation. In R. Landau and N. Rosenberg (Eds.), The positive sum strategy: Harnessing technology for economic growth (pp. 275-305). Washington, DC: National Academy Press.

Krause, P., Razavi, A., Moschoyiannis, S., and Marinos, A. (2009), Stability and Complexity in Digital Ecosystems. Proceedings of 3rd IEEE

International Conference on Digital Ecosystems and Technologies, 2000-2005.

Kasey Panetta, Gartner (July 12, 2017), Eight Dimensions of Business

Ecosystems https://www.gartner.com/smarterwithgartner/8-dimensions-ofbusiness-ecosystems/

Lee, E. A. (2008), Cyber Physical Systems: Design Challenges. 11th IEEE Symposium on Object Oriented Real-Time Distributed Computing (ISORC), 363 -369 .

Lemosa, Julio Cesar, Milton Freitas Chagas Juniorc (2016), Application of maturity assessment tools in the innovation process: converting system's emergent properties into technological knowledge, IMR innovation management review, RAI Revista de Administração e Inovação 13 (2016) 145-153.

Leydesdorff Loet and Ivanova Inga (2016), Open Innovation" and "Triple Helix" Models of Innovation: Can Synergy in Innovation Systems Be Measured? Journal of Open Innovations: Technology, Market and Complexity, 2(1) (2016) 1-12; doi:10.1186/s40852-016-0039-7.

Lom, M., Pribyl O., Svitek, M. (2016), Industry 4.0 as a Part of Smart Cities, Smart Cities Symposium 2016.

Lusch, F.R., Vargo, S.L., and Gustafsson, A. (2016), Fostering trans-disciplinary perspectives of service ecosystems. Journal of Business Research, vol. 69 (2016), August, pp. 2957-2963.

Marcos, M., Suárez, S., Marcos, M., Fernández-Miranda, S.S., Marcos, M., Peralta, M.E., and Aguayo, F. (2017), The challenge of integrating Industry in the 
degree of Mechanical Engineering. Procedia Manufacturing 13 (1) (2017) 12291236.

Marie Curin Accossiation (2020), (https://www.mariecuriealumni.eu/newsletter/definition-day-smartspecialisation-strategy)

Melnikovas A. (2018), Towards an Explicit Research Methodology: Adapting Research Onion Model for Futures studies, Aleksandras Melnikovas The General Jonas Žemaitis Military Academy of Lithuania. Journal of Futures Studies, December 2018, 23(2): 29-44 DOI:10.6531/JFS.201812_23(2).0003

Miller W. and Langdon, M. (1999), Fourth generation R\&D: Managing Knowledge, Technology, and Innovation. John Wiley \& Sons Inc., Canada.

Moore J.F. (1993), "Predators and Prey: A New Ecology of Competition," HARVARD BUSINESS REVIEW, vol. 71, 1993, pp. 75-83.

Muranganwa, R. (2016). Design and implementation of a multi-agent opportunistic grid computing platform. Doctoral dissertation. University of Fort Hare

Murthy, V. K. and Krishnamurthy, E.V. (2003), Entropy and Smart Systems. International Journal of Smart Engineering System Design, 5, 481- 490.

Nachira, F. (2002), “Towards a Network of Digital Business Ecosystems Fostering the Local Development," European Commission Discussion Paper. Bruxelles, 2002. pp. 11

Nachira, F. Dini P, Nikolai A (2007), a Network of Business Ecosystems for Europe: Roots, Processes and Perspectives," Digital Business Ecosystems. European Commission, Bruxelles. www. digital-ecosystems. org/book/debook2007. html, 2007.

Plattform Industrie 4.0 (2014), Plattform Industrie 4.0, 2014: Industrie 4.0. Whitepaper FuEThemen. Retrieved from http://www.plattformi 40. de/sites/default/files/Whitepaper_Forschung\%2oStand\%203.\%20April\%20201 4_o.pdf (30.11.2014).

Plattform Industrie 4.0 (2014), Plattform Industrie 4.0., 2014 Was Industrie 4.0 (für uns) ist. Retrieved from http://www.plattform-i40.de/was-industrie-40-f\% $\mathrm{C} 3 \% \mathrm{BCr}$-uns-ist (5.12.2014).

Burton, Besty (2017), Eight dimensions of business ecosystems, Gartner, June 2017 https://www.gartner.com/smarterwithgartner/8-dimensions-of-businessecosystems/

PwC, (2016) 4.0 Industry: Building the digital enterprise. Global Industry Survey.

Qin, J., Liu, Y. and Grosvenor, R. (2016), A Categorical Framework of Manufacturing for Industry 4.0 and Beyond. Procedia CIRP, 2016, 173-178. 
Raithatha, Y. (2017), Understanding the economic impact terrorism has on the destination decision making: Northern Irish tourists. Doctoral dissertation. Dublin Business School.

Ramdhani, A., Mnyamana, X., and Karodia, A. M. (2017), Investigating the Impact of Service Delivery on Consumer Satisfaction: A Case Study of FordGauteng Province, Republic of South Africa. Singaporean Journal of Business, Economics and Management Studies, 51(138), 1-30.

Razavi, A., Krausen, P.J., Abbas Strommen-Bakhtiar, (April 2010), From business ecosystems toward Digital Ecosystems, Conference paper DOI: 10.1109/DEST.2020.5610633

Reinsel, D., Gantz, J., and Rydning, J. (2018), The Digitization of the World from Edge to Core, An IDC White Paper - \#US44413318, November Seagate 2018. https://www.seagate.com/files/www-content/our-story/trends/files/idcseagate-dataage-whitepaper.pdf

Robson, C. (2002), Real-world research. 2nd ed. Padstow: Blackwell Publishing.

Rowley, J. (2002), Using Case Studies in Research, Management research news, 2002 - psyking.ne http://psyking.net/HTMLobj-3843/using_case_study_in_research.pdf

Sardar, Z., and Sweeney, J. A. (2016), The three tomorrows of post normal times. Futures, 75, 1-13.

Saunders, M., Lewis, P., and Thornhill, A. (2016), Research Methods for Business Students. England: Pearson Education Limited.

Saunders, M., Lewis, P., and Thornhill, A. (2000), Research Methods for Business Students. 2nd edition. Harlow: Pearson Education.

Schwab, K. (2018), The Fourth Industrial Revolution, what it means and how to respond. Retrieved from https://www.weforum.org/agenda/2016/o1/the-fourthindustrial-revolution-what-it-means-and-how- Jour of Adv Research in Dynamical \& Control Systems, Vol. 10, 14-Special Issue, 2018 ISSN 1943-023X Received: 20 October 2018/Accepted: 15 November 2018, 1387.

Schumpeter, J. (1982), A Teoria do Desenvolvimento Econômico: uma investiga , cão sobre lucros, capital, crédito, juro e o ciclo Econômico. São Paulo: Abril Cultural.

Singh, K. (2007), “Quantitative Social Research Methods” SAGE Publications, p.64.

Sterman J. (2000), Business Dynamics: Systems Thinking and Modelling for a Complex World. The McGraw-Hill Companies, Inc.

Tay S.I., Lee T.C., Hamid N-A., Ahmad A.N.A. (2018), An Overview of Industry 4.0: Definition, Components, and Government Initiatives, Jour of Adv Research in Dynamical \& Control Systems, Vol. 10, 14-Special Issue, 2018 ISSN 1943O23X. 
Tamayo-Orbegozo, Unai, Vicente-Molina, Maria-Azucena, Villarreal-Larrinaga, Oskar (2017), Eco-innovation strategic model. A multiple-case study from a highly eco-innovative European region. J. Clean. Prod. 142, 1347-1367. https://doi.org/10.1016/ j.jclepro.2016.11.174.

Tashakkori, A., and Teddlie, C. (1998), Mixed Methodology: Combining Qualitative and Quantitative Approaches. Applied Social Research Methods Series, 46; Thousand Oaks: Sage Publications.

Teece, D.J. (2007), "Explicating dynamic capabilities: The nature and micro foundations of (sustainable) enterprise performance", Strategic Management Journal, Vol. 28, pp. 1319-1350.

Tether, B. S. (2003), What is innovation? (working paper n. 12). Manchester: University of Manchester and UMIST, ESRC Centre for Research on Innovation and Competition (CRIC).

Tidd, J., Bessant, J., and Pavitt, K. (2008), Gestão da Inova , cão (3rd ed.). PortoAlegre, Bookman.

Tilson, D., Lyytinen, K., and Sørensen, C. (2010), "Research Commentary Digital Infrastructures: The Missing IS Research Agenda," Information Systems Research (21:4), pp. 748-759.

Tuomi, J. and Sarajärvi, A. (2002). Laadullinen tutkimus ja sisällönanalyysi. Helsinki: Tammi.

Tushman, M. L. and O'Reilly, C. (1996). Ambidextrous organizations: Managing evolutionary and revolutionary change. California Management Review,38(4), 8-30.

Utterback, J. M. (1996), Dominando a Dinâmica da Inova , cão. Rio de Janeiro: Qualitymark.

Valdez-de-Leon, O. (2015), Elements and Enablers: How to Develop an Operator IoT Ecosystem. Ericsson Business Review. Accessed May 14, 2019 https://www.slideshare.net/omarvl/elements-andenablers-how-to-develop-anoperator-iot-ecosystem

Valdez-De-Leon, O. (2019), How to Develop a Digital Ecosystem: a Practical Framework. Technology Innovation Management Review August (Vol. 9, issue 8).

Van Alstyne, M. W., Parker, G. G., and Choudary, S.P. (2016), Pipelines, Platforms, and the New Rules of Strategy. Harvard Business Review, 94(4): 5462.

World Economic Forum (2019) Harnessing the Fourth Industrial Revolution for the Circular Economy, January 2019, Geneva, Switzerland.

Yin, R.K. (1994), Case study research: design and methods. 2nd edition. Thousand Oaks, CA: Sage. 
Publication A, Towards Smart City Concept in Small Cities

Authors: Heikki Ruohomaa, Vesa Salminen \& Iivari Kunttu

TIM Review, September 2019, Volume 5 ( https://timreview.ca/article/1264) 


\title{
Towards a Smart City Concept in Small Cities
}

\author{
Heikki Ruohomaa, Vesa Salminen, Iivari Kunttu
}

\author{
"The greatest danger of turbulence is \\ not the turbulence - It is to act with \\ yesterday's logic".
}

Peter Drucker

The smart city concept brings together technology, government and different layers of society, utilizing technological enablers, such as the internet of things (IoT) and artificial intelligence(AI). These enablers, in turn, facilitate development of various aspects of the smart city including, e.g.,

transportation, governance, education, safety and communications. However, the transition towards smarter cities involves not only technological development but also the changing and evolving roles of citizens, service providers and city authorities. In this transition, the key issue is creating and growing roles of collaboration, participation and coordination. Whereas mainstream research focuses on smart city transformation in big cities, aspects of this transformation in the context of small cities has been a widely neglected topic. This paper presents three cases of smart city development in small cities in Finland, each concentrating on a different aspect of smart city development. The cases reveal how a relatively small-sized city may take remarkable steps in smart city development by selecting a specific theme on which to build smart city activities. These examples also emphasize the critical role of public sector actors, showing that the public public sector has a key role in creating the foundations for fruitful ecosystem-based development work.

\section{Introduction}

It is not just corporations that are seeing rapid changes due to major global challenges, such as globalization, climate change and digitalization. Societies, cities and regions are also experiencing these changes. Today, 55 of the world's population lives in urban areas, a proportion that is expected to increase to 68 by 2050 (United Nations, 2018). Thus, the speed and complexity of change also challenge leadership, organizational structures, R\&D activities, education and training, and value chains. Ecosystem-based 
development is considered to be an option that will facilitate management of change at governmental, national, regional and company level.

The World Economic Forum report (Fourth Industrial Revolution for the Earth Series, 2018), following the work of Klaus Schwab, terms the period of accelerating innovation in science and technology as the "fourth industrial revolution". The technologies of the fourth industrial revolution have generated growing interest in the opportunities they offer as well as concern about governance, regulation and ethics (Fourth Industrial Revolution for the Earth Series, 2018). Combining artificial intelligence (AI) with big data - not to mention exponential accumulation of data itself - has created a fascinating world of communications, collaboration and interaction, not just between people but also between machines, as well as between people and machines (Salminen, Kantola and Ruohomaa., 2016). As a result, the industry 4.0 framework defines the context for digitalization and industrial IoT. This framework contains the connectivity of devices for effective value chain management using sophisticated data collection as well as data-based optimization and analysis. For this reason, industry 4.0 also provides a detailed and solid framework for development work related to smart cities (Lom, Pribyl and Svitek, 2016) because activities related to data collection, interpretation and analysis (in support of rational decision-making and planning) are central to creating smart city services in the value chain network.

The purpose of this paper is to make a practical contribution to the wideranging literature on smart city development by presenting three practical cases on smart city development in small Finnish cities. The cases reveal that the commitment of key stakeholders is essential to sustainable development work in this area. The results also underline the importance of providing a platform for new development and pilot studies of ecosystem-based development. The rest of the paper is organized as follows: section 2 describes a framework for smart cities, based on a concise review of literature in this field, with an emphasis on digital participation and collaborative processes enabled by digitalization. Section 3 presents three case studies about small city development in a rural region of Finland. Section 4 discusses the results and gives guidelines for further research in this field.

\section{Smart City Concept}

The smart city concept derives from the intersection of studies in urbanism and information and communication technology (ICT), combined with the 


\section{Acta Wasaensia}

dimensions of creativity and humanity (Nam and Pardo, 2011; Pereira et al., 2017). The smart city concept represents new ways of organizing city functions and urban life for environmental purposes, based on digitalization (Öberg, Graham and Hennelly, 2017). In the field of ICT, rapid development of software, hardware and networks has made it technologically possible to connect people and the facilities that serve their everyday needs in cities (Pereira et al., 2017). Thus, the smart city concept brings together technology, government and different layers of society, utilizing technological enablers, such as the internet of things (IoT) and artificial intelligence (AI). These enablers, in turn, facilitate development of various aspects of the smart city, including, e.g., transportation, governance, education, safety and communications. Thus, different and often complementary aspects of asmart city encompass an efficience, technological advancement, sustainability and social inclusivity (Vanolo, 2014). General trends in this kind of development include the transition from global to local production and consumption, a change from competitive to collaborative manufacturing and service provision, and a move from shareholder-based businesses to multiple stakeholder viewpoints (Herrschel, 2013; Öberg, Graham and Hennelly, 2017).

Smart city development requires not only technological enablers but also a new way of thinking among cities, businesses, citizens and academia, which includes key development stakeholders. In this manner, close collaboration between universities and the private sector must be maintained, and the main objective should be shared learning (Ruohomaa, Mäntyneva and Salminen, 2018). This kind of long-term cooperation creates a background for new coinnovation and co-evolution. 


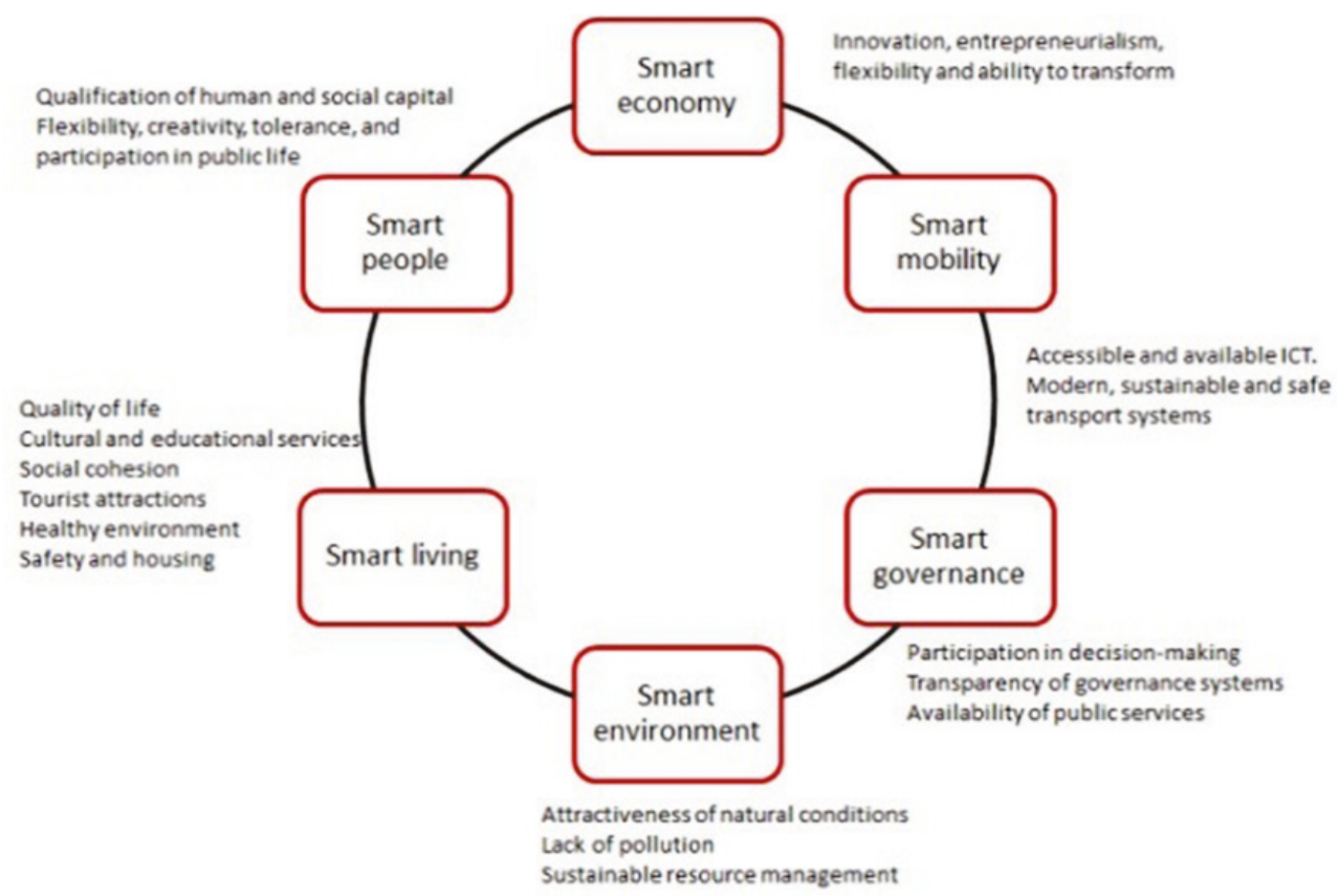

Figure 1. Dimensions of the smart city concept, adapted from Giffinger and Suitner (2015)

The transition towards smarter cities involves changing and evolving stakeholder roles (Lom, Pribyl and Svitek, 2016). Citizens should no longer be considered as merely users but rather as stakeholders with an active role; as participants, collaborators and developers in the city's activities. In the same manner, technology should no longer be considered as an asset but as a dynamic enabler in smart city development. Moreover, in this framework, business is no longer viewed as a provider but rather as a collaborative partner. These new roles, together with the ecosystems formed by smart cities, establish a framework for a new kind of development in urban areas. In this framework, it is important to understand that smart city development does not mean merely providing new digital services for citizens. Rather, it is a transformative process involving city structures, governance and functions, as well as interaction and collaboration between city stakeholders (Vanolo, 2014).

Smart city initiatives have recently been merged into a model to make cities better places to live in. The smart city can thus be considered as an ideal of sustainable urban living. It is nevertheless a rather vague concept, defined in various ways depending on the context of smartness (Öberg, Graham and 
Hennelly, 2017). According to Giffinger and Suitner (2015), the concept of a smart city should incorporate at least one of the following dimensions (Figure 1): 1) a smart economy related to, e.g., innovation, entrepreneurship, flexibility or productivity; 2) smart mobility in the context of sustainable resource management and transport systems; 3) smart governance with implications for participation, decision-making and transparent governance structures; 4) a smart environment that is understood to provide attractive, natural conditions and a lack of pollution, as well as sustainable management of resources and energy; 5) smart living and quality of life; and 6) smart people in terms of qualifications, creativity, education and flexibility (Vanolo, 2014). In this manner, smartness in the smart city context can be associated with very different phenomena. One factor that these phenomena have in common is sustainability, which is included in one form or another in almost all of the above-mentioned dimensions (Öberg, Graham and Hennelly, 2017). Moreover, Herrschel (2013) suggests that the smartness of smart cities has come to include "innovativeness, participation, collaboration, and coordination". This highlights the role of smart processes, collaborative practices and ways of working as opposed to pure ICT-based technological development. The latter is seen as an enabler, rather than as a key element of the smart city concept. Despite this rather broadly defined framework, previous literature in the field of smart city development is relatively coherent in suggesting that digitalization and urbanization are making production and consumption less global and more local, thus changing manufacturing from competitive to collaborative and business from a single shareholder basis to multiple stakeholders (Öberg, Graham and Hennelly, 2017). In this context, data-driven service operation can be used to significantly improve service performance, by implementing the right data strategy (Pulkkinen, Jussila, Partanen and Trotskii, 2019).

Figure 2 displays the essential framework for a digital ecosystem in smart city transformation (Ruohomaa and Salminen, 2019). In this framework, the general architectural layer enables the involvement of private- sector partners. At the same time, the players in this framework form an ecosystem that consists of inhabitants, tourists, companies and the city itself. 


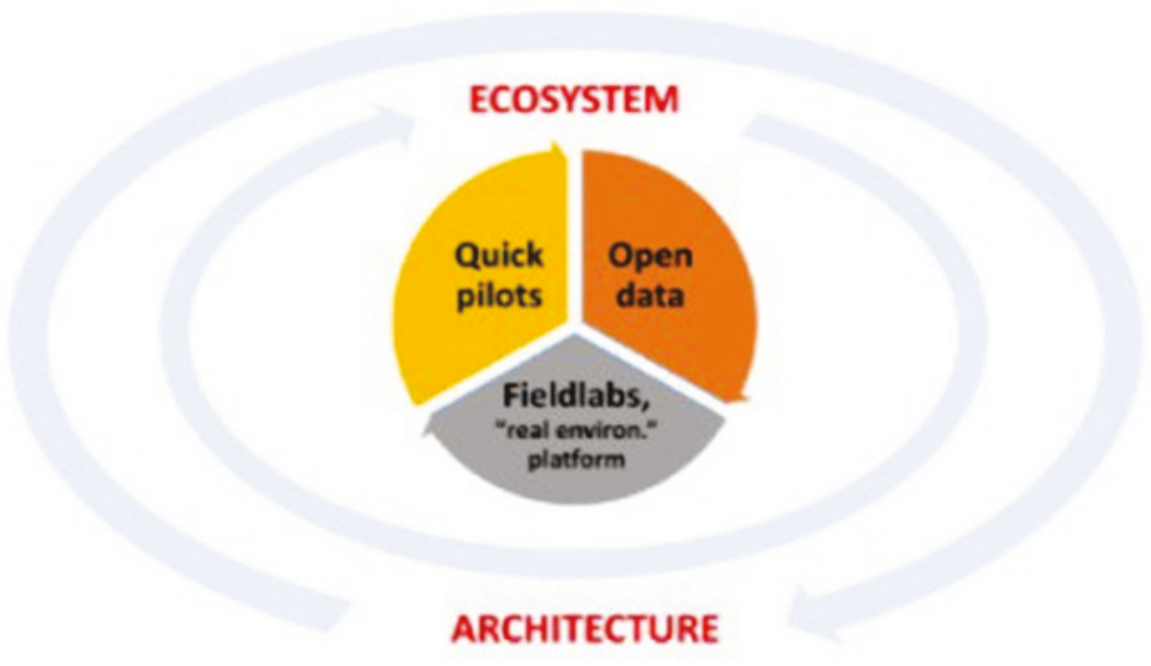

Figure 2. Digital ecosystem in a smart city context (Ruohomaa and Salminen, 2019)

The concept of a city's 'smartness' can be understood on three conceptual levels (Lom, Pribyl and Svitek, 2016). Firstly, in the context of marketing, smartness involves user perspective. The smart services related to smart cities are linked to user-friendliness, which means that smart cities require conceptual adaptations to end user needs and interfaces with the city's inhabitants (Marsá Maestre et al., 2006). Secondly, in the context of strategic management and development, the smart city concept is directly related to the strategic and ideological directions taken by urban planning. This is because public actors, such as governments and cities, at all levels, utilize the concept of smartness to distinguish their new strategies, development programmes and policies, as a guideline for the development of urban areas in terms of economic growth, sustainable development and better quality of life. Smart governance (or e-governance) means that various key stakeholders are engaged in decision- making and public services through, e.g., social media, open data or other internet-based participation platforms (Pereira et al., 2017). A key issue in facilitating these kinds of participatory tools and services is collaboration across departments and communities; which tests the real user-centeredness of these services. Thirdly, in the context of technological development, enablers of the smart city concept utilize the methods of artificial intelligence (AI), the internet of things (IoT), and machine learning (which all rely on sophisticated data collection and analysis), to apply these commercially. These technological enablers facilitate the development and deployment of ICT-related aspects of smart cities, e.g., smart transportation, smart energy, smart education, smart safety and smart communication (Lom, Pribyl and Svitek, 2016). Together, these three levels of the smart city concept form a smart city ecosystem, which represents an extension of smart space from personal surroundings to the 
larger community and entire city. Table 1 illustrates the basic characteristics of the smart city ecosystem.

Table 1. Characteristics of a smart city ecosystem

\begin{tabular}{|c|c|c|c|}
\hline Context & General direction & User point of view & $\begin{array}{l}\text { Governance point } \\
\text { of view }\end{array}$ \\
\hline Marketing & $\begin{array}{l}\text { User pers pective is } \\
\text { emp has ized. }\end{array}$ & $\begin{array}{l}\text { Usable, accessible } \\
\text { and user-friendly } \\
\text { digital services. }\end{array}$ & $\begin{array}{l}\text { Service process } \\
\text { needs to be } \\
\text { adapted to user } \\
\text { needs and } \\
\text { interfaces. }\end{array}$ \\
\hline $\begin{array}{l}\text { Strategic } \\
\text { management } \\
\text { and } \\
\text { Governance }\end{array}$ & $\begin{array}{l}\text { Governments and cities } \\
\text { at all levels utilize the } \\
\text { concep t of smartness to } \\
\text { engage various } \\
\text { stake holders in decision- } \\
\text { making. }\end{array}$ & $\begin{array}{l}\text { Citizens are } \\
\text { considered as key } \\
\text { stake holders, } \\
\text { participating in } \\
\text { decision-making } \\
\text { and city } \\
\text { development } \\
\text { through } \\
\text { participation tools. }\end{array}$ & $\begin{array}{l}\text { Cities facilitate } \\
\text { participatory } \\
\text { planning and } \\
\text { decision-making by } \\
\text { providing citizens } \\
\text { with digital } \\
\text { participation } \\
\text { options. }\end{array}$ \\
\hline Technology & $\begin{array}{l}\text { Utiliz ation of } \mathrm{AI}, \mathrm{IO} \mathrm{T} \text { and } \\
\text { machine le arning } \\
\text { together with data } \\
\text { analysis to provide smart } \\
\text { services. }\end{array}$ & $\begin{array}{l}\text { Improving quality } \\
\text { of life through } \\
\text { smart services. }\end{array}$ & $\begin{array}{l}\text { Providing citizens } \\
\text { with relevant digit al } \\
\text { services, facilitating } \\
\text { sus tainable living } \\
\text { in cities. }\end{array}$ \\
\hline
\end{tabular}

\section{Case Studies}

The purpose of this paper is to consider smart city transformation in small cities by focusing on selected areas. In this section, we present three cases, each focusing on one small city in Finland. In the first case, we present the case of Hämeenlinna. In its ecosystem- based development work, this city has faced a cumulative increase of data, and has used new technologies to respond to the rapid change and complexity of the business environment. The case study is based on the smart mobility part of the framework in relation to bikes. The second case considers the town of Riihimäki. Riihimäki relies on smart specialization by adapting digitalization and robotics to improve the overall competitiveness of local business, society, educational environments and city services. The third case presented is that of Forssa. The Forssa case focuses on a circular economy in terms of industrial development and town 
services. In this manner, experience and understanding of the circular economy and industrial symbiosis have facilitated greater understanding of how to develop smart living, education and tourism in the Forssa region. Table 2 summarizes the key characteristics of each smart city development case.

\section{The Case of Hämeenlinna}

The city of Hämeenlinna has recently started ecosystem development work aimed at improving the town's competitiveness and sustaining its surrounding region. Key stakeholders involved in ecosystem work include city authorities, local companies, the local university and other educational institutions, as well as city inhabitants. Digitalization and developing smart city services are among the key targets of this ecosystem building work (Kunttu, 2019). Weveral pilot projects have been initiated to develop smart city services in Hämeenlinna.

The pilot project presented in this paper is an electronic bike service, which will be detailed along with data that can be collected for further use (Figure $3)$. As part of the smart mobility concept, the bike-share operators and cities in which they operate want bike-share travel to become a viable part of the transportation system for city residents. In this manner, bike sharing is a city transport solution and a smart answer to urban mobility, providing a competitive alternative to private cars and existing public transport services (Dennis, 2018). In the Hämeenlinna bike project, yellow-and-green bikes are made available in selected locations around the city (see Figure 4). Users can check the availability of the bikes and rent one by using a smartphone application. Open data provided by the bike-sharing service are utilized in several ways. In the direct data-based service, users are able to see the availability of bikes in the town. In the indirect services, data are used by the bike operators to ensure availability and also to maintain the bikes. The city authorities are also aiming to utilize the collected bike data to plan cycle routes and services for bikers.

\section{The Case of Riihimäki}

The town of Riihimäki bases its strategy on robotics for developing an attractive business environment. Since robotics has been selected as the strategic focus area for the town, the authorities are committed to long-term development and implementation of robotics in a wide range of life and working environments. Development activities in Riihimäki are interlinked, 
and follow the European industry 4.0 framework to ensure crossjurisdictional comparability and compatibility. An industry 4.0 framework with robotics can also be used to indicate intent to the European Digital Single Market, and thus attract new business to the town. To ensure implementation, it is necessary to have an open atmosphere so that stakeholders, including citizens, business actors and town authorities, can participate in robotics development and innovation activities. By involving multiple stakeholders, it is possible to reduce resistance to change, increase commitment, and obtain new development ideas.

Table 2. Characteristics of each city in the case study

\begin{tabular}{|c|c|c|c|}
\hline & Hämeenlinna & Forssa & Riihumaaki \\
\hline \multirow{2}{*}{$\begin{array}{l}\text { Number of } \\
\text { inhabitants } \\
\text { Focus areas }\end{array}$} & 67,000 & 20,000 & 28,000 \\
\hline & $\begin{array}{l}\text { Education, local } \\
\text { governance, military } \\
\text { base }\end{array}$ & Circular economy & $\begin{array}{l}\text { Manufacturing } \\
\text { industry }\end{array}$ \\
\hline $\begin{array}{l}\text { Focus area in } \\
\text { smart city } \\
\text { development }\end{array}$ & Smart mobility & $\begin{array}{l}\text { Smart enviro nment } \\
\text { (circular economy) }\end{array}$ & $\begin{array}{l}\text { Smart living } \\
\text { (service ro botics) }\end{array}$ \\
\hline $\begin{array}{l}\text { Smart city } \\
\text { pilots }\end{array}$ & Bike-sharing service & $\begin{array}{l}\text { Recycling and } \\
\text { waste management } \\
\text { services }\end{array}$ & $\begin{array}{l}\text { Robotics in } \\
\text { education and } \\
\text { elderly care }\end{array}$ \\
\hline
\end{tabular}

Utilization of robotics and digitalization requires new skills (not only technical but also multidisciplinary) and a broad approach. For this reason, the town of Riihimäki has invested heavily in educational robotics activities, ranging from nurseries and elementary schools, to university level and lifelong learning for adults, integrating this with the needs of various sectors, including industry, health care, education, and traffic. Education is not only seen as a way of building know-how, but also of reducing resistance to change, speeding up implementation and promoting a positive attitude to robotics. Education is also fundamental to innovation when it takes place in "real-life" environments, in pilots and quick trials. The town has also arranged several events related to robotics, including competitions and development challenges for students. The city has also collaborated closely with the local university on these activities. 


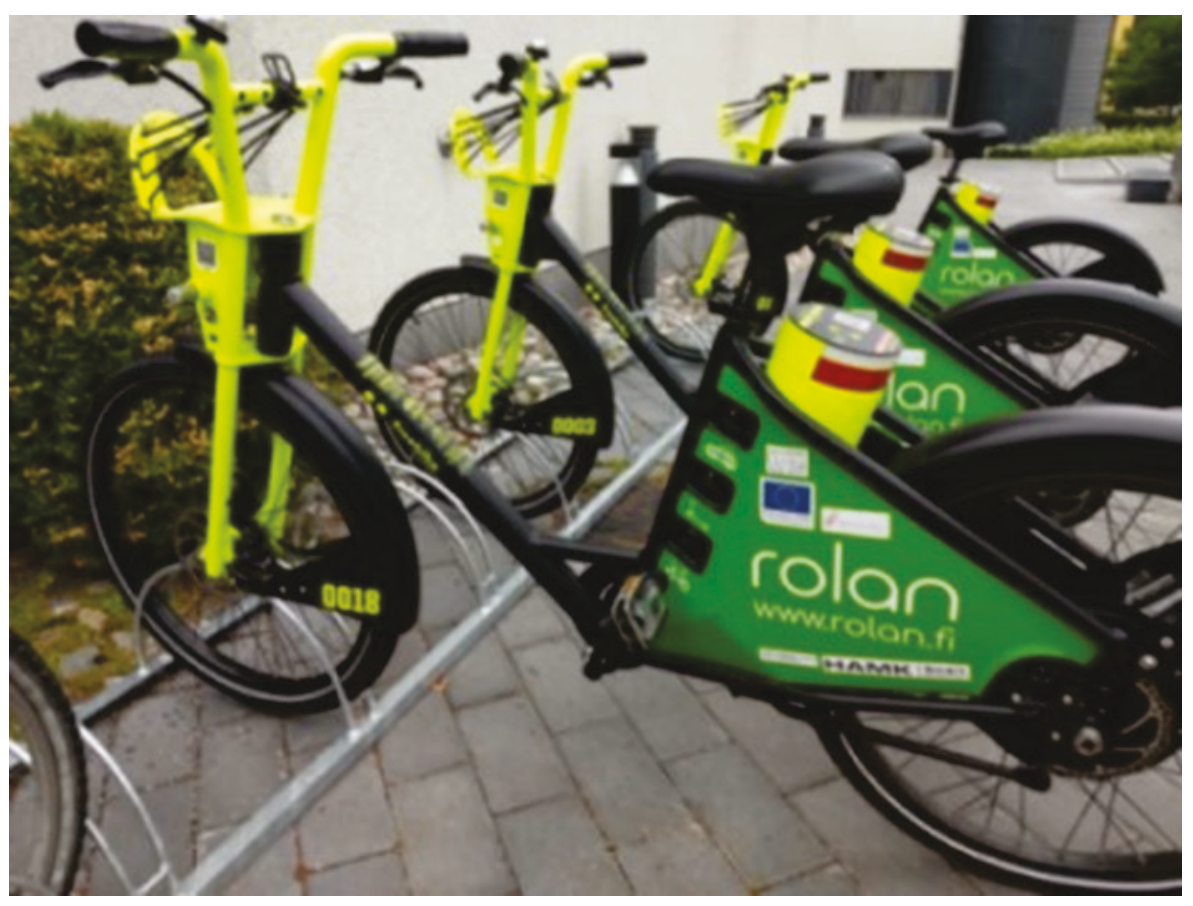

Figure 3. Bike-sharing service at Hämeenlinna railway station

The three main areas of robotics development in Riihimäki are production robotics (focusing on industrial automation and manufacturing), service robotics and the robotics of health care. The pilots for these three aspects are being undertaken in various parts of the city. For example, care associations are running pilots for service robotics in the field of elderly care (Bäck et al., 2012; Bäck, Mäkela and Kallio, 2013) in collaboration with the local university. 


\section{Acta Wasaensia}

\section{The Case of Forssa}

The town of Forssa is in the middle of the Finnish agricultural landscape, located within a triangle formed by the three largest cities in Finland, and with good transportation connections. The largest national research institute for agriculture and bioeconomy is also located in the Forssa region. In addition, the bioeconomy and agriculture departments of the regional university of applied sciences are located there.

The history of the Forssa circular economy business ecosystem dates to the 1990s, when the first EU waste treatment directive was launched. Because of this, Forssa and the surrounding municipalities decided to create a large landfill area, where all the companies involved with waste handling or treatment could be located. Since then, several companies operating in the waste management business have moved to this area. Their close proximity makes it easy for these companies to cooperate with one another, and in this way an ecosystem has been created for a circular economy and industrial symbiosis. The circular economy ecosystem in Forssa is currently ranked the best in Finland.

Nowadays, in the Forssa region, strategic focus is placed on a circular economy. R\&D funding is used for the development of this circular economy, and the local university has adapted its degree programmes to support circular economy education. The local authorities are highly supportive of ecosystembased development, and new start-ups focusing on circular economy activities. Figure 5 presents a visualization of industrial symbiosis of the circular economy ecosystem in Forssa. Based on this, the town of Forssa and its surrounding regions are being branded as the "Smart Green Forssa Region". Also related, Forssa hosts an annual circular economy event for start-ups and growth enterprises (FRUSH) to make its activities visible, attract investors and promote circular economy-related start- ups.

The city of Forssa has also selected the circular economy and smart city development as part of its strategic focus. The reason behind this is the fact that although the circular economy and industrial symbiosis were largely driven by industry at the outset, these developments have had a marked impact on the of city of Forssa, and have led to increased understanding and thinking among its citizens generally. Thus, the city strongly supports resource efficiency and circular economy development in its everyday activities. Circular economy thinking has had a major impact on education, environment, living, services and tourism. A concrete example of this is the 
local waste management facility, which continuously produces new user innovations for smart recycling and effective resource utilization.

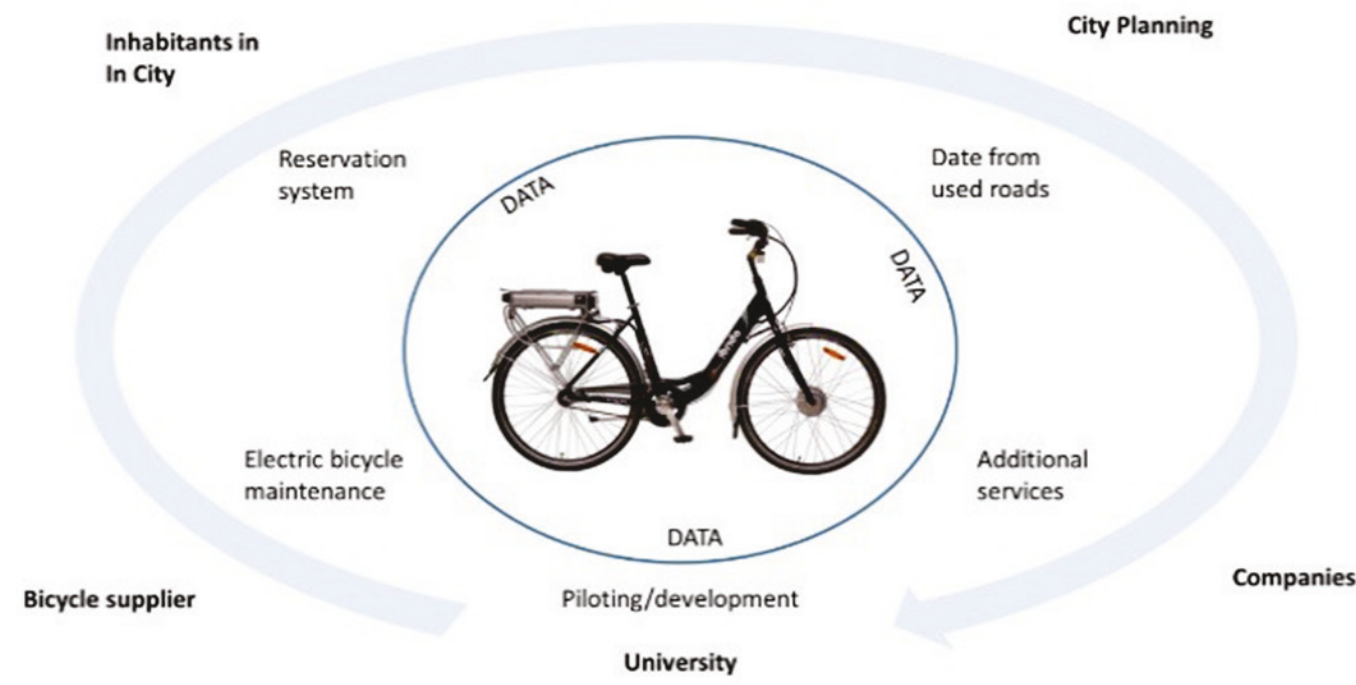

Figure 4. Pilot of the electric bicycle digital ecosystem

\section{Conclusion}

In the existing literature related to smart city development, a wide consensus exists on the need to build new smart city solutions because of urbanization, user expectations, technological development, and environmental challenges. This paper presented practical viewpoints, cases and experiences relating to the planning of smart cities, and the availability of services. We also considered how these examples could be used as a tool for city planning in a smart city context. In this way, the paper may provide helpful information based on "lessons learned", relevant to all the actors involved and interested to participate in smart city development (and the fundamental services themselves).We presented a case study of three small cities in southern Finland, all of which had selected to undertake smart city development in a clearly defined area directly related to the strategic focus of the city or region. In this manner, a common denominator for the cases was that each town is basing its smart city activities in key strategic areas. In all three cases, the towns were actually platforms for smart city development projects, which enable inhabitants and other stakeholders to participate in planning and development, and thus become part of the ecosystem. 


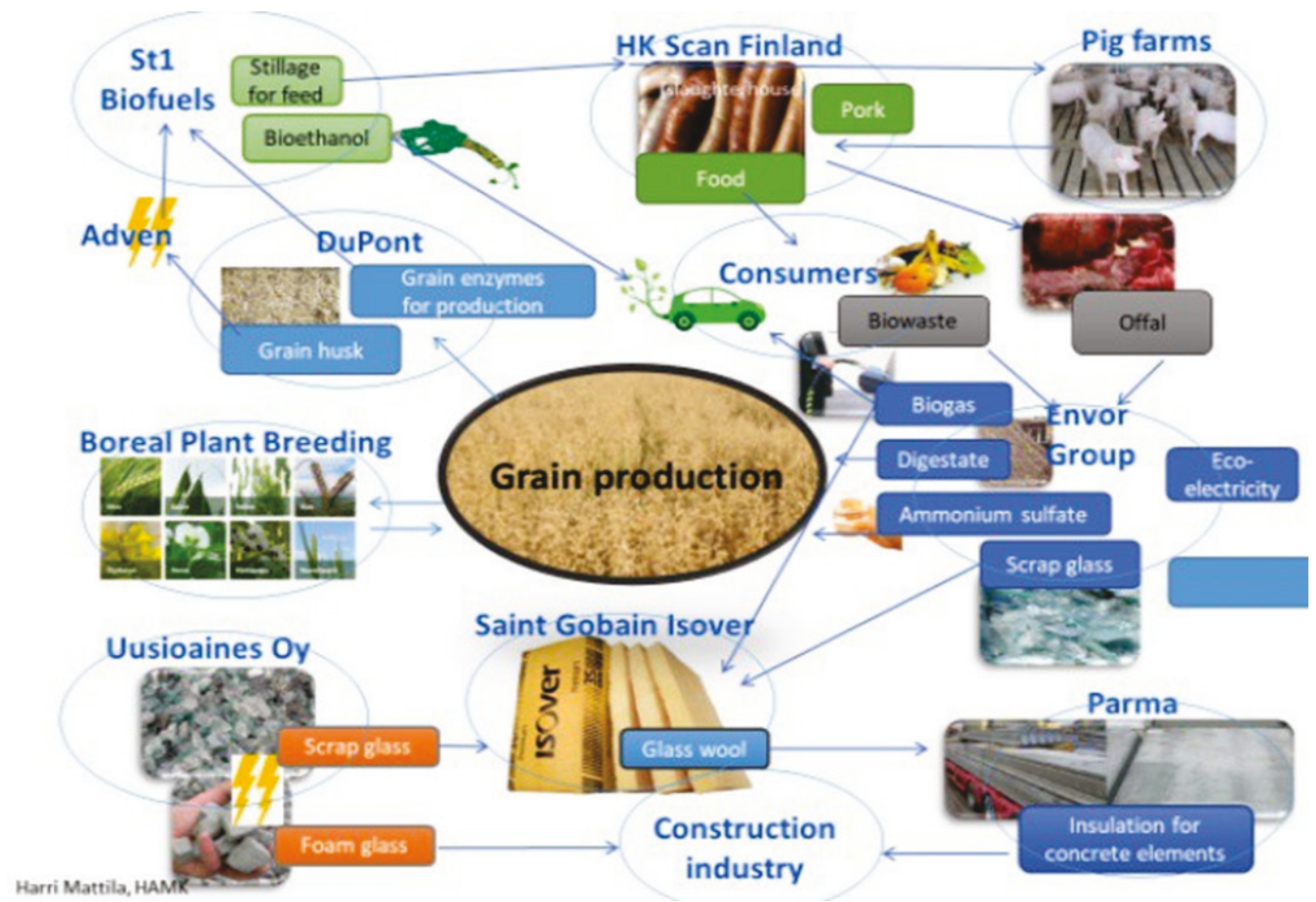

Figure 5. Efforts made in the Forssa region to visualize local bio-based industrial symbiosis

These case studies show that the public sector has a fundamental role in fruitful ecosystem-based development. They reveal larger initiatives where towns are moving their development activities towards ecosystem-orientation. This is changing what it means to be organized so that an ecosystem can be more responsive to the impact of digitalization and increasing amounts of data. 


\section{References}

Dennis, A. L. 2018. Case Study: Artificial Intelligence Helps Bike-Share Programs Get Smart. https://www.dataversity.net/case-study-bike-shareprograms-get-smart-artificialintelligence/?fbclid=IwAR3adaqrjlFnRlnmKTEVd7XS EsVwe0ny tLWLZI4L97OgRmX8_pAowDrTK9

Bäck, I. et al. 2012. Monitoring of nursing home residents using a humanoid robot. Journal of Telemedicine and Telecare, 18: 357-361.

Bäck, I., Mäkela, K. and Kallio, J. 2013. Robot-guided exercise program for the rehabilitation of older nursing home residents. Annals of Long-Term Care, 21(6): 38-41.

Fourth Industrial Revolution for the Earth Series. 2018. Harnessing the Fourth Industrial Revolution for Life on Land - Towards an Inclusive BioEconomy. World Economic Forum, January 2018, Geneva, Switzerland.

Giffinger, R. and Suitner, J. 2015. Polycentric metropolitan development: from structural assessment to processual dimensions. European Planning Studies, 23(6): 1169-1186.

Herrschel, T. 2013. Competitiveness AND Sustainability: Can "Smart City Regionalism" Square the Circle? Urban Studies, 50(11): 2332-2348. doi: $10.1177 / 0042098013478240$

Kunttu, I. 2019. Developing smart city services by mobile application. ISPIM Connects, Ottawa, Innovation for Local and Global Impact, 7th-10th April 2019.

Lom, M., Pribyl, O. and Svitek, M. (2016). Industry 4.0 as a Part of Smart Cities. 2016 Smart Cities Symposium Prague (SCSP). IEEE. doi: 10.1109/SCSP.2016.7501015

Marsá Maestre, I. et al. (2006) Mobile Personal Agents for Smart Spaces. In IEEE International Conference on Pervasive Services: 299-302. doi: 10.1109/PERSER.2006.1652247

Nam, T. and Pardo, T. A. (2011). Conceptualizing smart city with dimensions of technology, people, and institutions. The Proceedings of the 12th Annual International Conference on Digital Government Research: 282-291. doi:10.1007/978-3-540-68894-5_7

Öberg, C., Graham, G. and Hennelly, P. 2017. Smart cities: a literature review and business network approach discussion on the management of 
organizations. IMP Journal, 11(3): 468-484. doi: 10.1108/IMP-06-20150024

Pereira, V. G. et al. 2017. Increasing collaboration and participation in smart city governance: a cross-case analysis of smart city initiatives. Information Technology for Development, 23(3): 526-553.

Pulkkinen, J., Jussila, J., Partanen, A. and Trotskii, I. 2019. Data strategy framework in servitization: Case study of service development for a vehicle fleet. Research and Innovation Forum, Rome, 24th-26th April 2019.

Ruohomaa, H. and Salminen, V. 2018. Regional Development in Modern Robotic Education on Industrial and Society Context. AHFE 2018, Florida, 21 st-25th June 2019.

Ruohomaa, H. and Salminen, V. 2019. Mobility as a service in small cities new concept for smart mobility in Industry 4.0 framework. ISPIM Connects, Ottawa, Innovation for Local and Global Impact, 7th-10th April 2019.

Ruohomaa, H., Mäntyneva, M. and Salminen, V. 2018. Renewing a University to Support Smart Manufacturing within a Region. Digital Transformation in Smart Manufacturing, chapter 8, IntechOpen.

Salminen, V., Kantola, J. and Ruohomaa, H. 2016. Digitalization and Big Data Supporting Responsible Business Co-Evolution. 2nd International Conference on Human Factors, Business Management and Society (inside the AHFE 2016), Orlando, USA, 27th-31st July 2016.

United Nations. 2018. 68 of the world population projected to live in urban areas by 2050. https://www.un.org/development/desa/en/news/po pulation/2018-revision-of-world-urbanization-prospects.html

Vanolo, A. 2014. Smartmentality: The Smart City as Disciplinary Strategy. Urban Studies, 51(5): 883-898. doi: 10.1177/0042098013494427 
About the Authors

Mr. Heikki Ruohomaa is currently as research manager in the HAMK Smart Research Centre at Häme University of Applied Science. He is involved with various research activities, education ja industrial implementation. His areas of expertise include ecosystem-based development, circular economy and Industry 4.0. He has also worked actively for regional development.

Dr. Vesa Salminen is currently acting as research director in the HAMK Smart Research Centre at Häme University of Applied Sciences. He is involved with various research activities, education and industrial implementation. His areas of expertise include innovation leadership, the data-to-service process, industrial service business, competence management and strategic management of business transitions. He previously worked as industrial professor at Lappeenranta University of Technology and spent two years as senior research scientist at the Massachusetts Institute of Technology, MIT, Boston. He has over 25 years' industrial experience, which includes being managing director of Spiral Business Services Corp., technology expert at Technology Industries of Finland, and marketing/sales/project expert at Valmet Corp. Salminen has published over 200 refereed journal articles, book chapters and conference articles, e.g., through Springer Publishing, Elsevier Publishing, Intech Media, IEEE Publishing, ASME Publishing, IST Publishing and IGI Global Publishing.

Dr. Iivari Kunttu holds a PhD degree in Information Technology from the Tampere University of Technology (TUT, 2005), and a PhD degree in Economics (management) from the University of Vaasa, Finland (2017). Currently he acts as Principal Research Scientist in Häme University of Applied Sciences. In 2012-2017, he held an Assistant Professor position in Department of Management at the University of Vaasa. He has also held several R\&D Manager and R\&D process development specialist positions in the Nokia Corporation, and project manager positions in TUT. His current research interests include $R \& D$ and innovation management, data analysis, business development, as well as digital services. His works have been published in such international journals as Pattern Recognition Letters, Machine Vision Applications, Optical Engineering, Journal of Telemedicine and Telecare, Annals of Long-term Care, Technovation, Industry and Innovation, and Technology Innovation Management Review. 


\section{Acta Wasaensia}

Citation: Ruohomaa, H, Salminen, V, \& Kunttu. I. 2019. Towards a Smart City Concept in Small Cities. Technology

Innovation Management Review, 9(9): 5-14.

http://doi.org/10.22215/timreview/1264

Keywords: smart city; regional development; industry 4.0; ecosystem-based development; mobility; robotic; circular economy.

Academic Affiliations and Funding Acknowledgements

\section{Carleton \\ U N I V E R S I T Y}

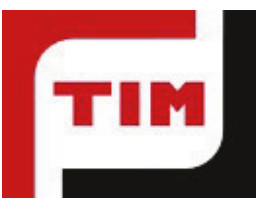

Technology Innovation Management (TIM; timprogram.ca) is an international master's level program at Carleton University in Ottawa, Canada. It leads to a Master of Applied Science (M.A.Sc.) degree, a Master of Engineering (M.Eng.) degree, or a Master of Entrepreneurship (M.Ent.) degree. The objective of this program is to train aspiring entrepreneurs on creating wealth at the early stages of company or opportunity lifecycles.

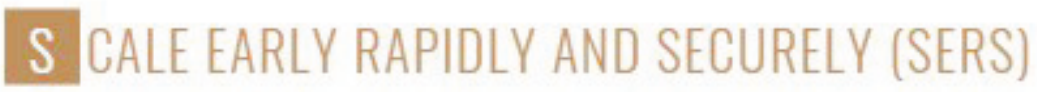

The TIM Review is published in association with and receives partial funding from the TIM program.

The TIM Review team is a key partner and contributor to the Scale Early, Rapidly and Securely (SERS) Project: https://globalgers.org/. Scale Early, Rapidly and Securely (SERS) is a global community actively collaborating to 
advance and disseminate high-quality educational resources to scale companies.

The SERS community contributes to, and leverages the resources of, the TIM Review (timreview.ca). The authors, readers and reviewers of the TIM Review worldwide contribute to the SERS project. Carleton University's Technology Innovation Management (TIM) launched the SERS Project in 2019

We are currently engaged in a project focusing on identifying research and knowledge gaps related to how to scale companies. We are inviting international scholars to join the team and work on shaping Calls for Papers in the TIM Review addressing research and knowledge gaps that highly relevant to both academics and practitioners. Please contact the Editor-inChief, Dr. Stoyan Tanev (stoyan.tanev@carleton.ca) if you want to become part of this international open source knowledge development project. 
90 Acta Wasaensia

\section{ORIGINAL PUBLICATION B}

Publication B. Renewing a University to Support the Smart Manufacturingin Within a Region

Ruohomaa, Heikki, Mäntyneva, Mikko, Salminen, Vesa. InTechOpen (2018)

ISBN: 978-953-51-3842-6 Print ISBN: 978-953-51-3841-9 DOI: 10.5772/intechopen.69336 


\title{
Renewing a University to Support Smart Manufacturing Within a Region
}

Heikki Ruohomaa, Mikko Mäntyneva and Vesa Salminen

Additional information is available at the end of the chapter http://dx.doi.org/10.5772/intechopen.72115

\begin{abstract}
This chapter focuses on the topic of renewing a university in order to be able to sup- port the adaptation of smart manufacturing and Industry 4.0 within a region. The chapter introduces Industry 4.0 as a framework for regional development. Factors related to Industry 4.0 related renewal in the region are identified and discussed further. An idea of how to apply Industry 4.0 as a framework for renewal of a multidisciplinary university's structure and curricula is introduced. Also, a case study for applying Industry 4.0 as a framework for increasing competitiveness in the region is introduced.
\end{abstract}

Keywords: Industry 4.0, smart manufacturing, regional development, university

\section{Introduction}

The chapter is closely linked to Industry 4.o framework. The geographic focus, while developing this chapter further, is the region of Häme in the southern part of Finland. The various activities within the region are evaluated from the perspective of smartness and their ability to support Industry 4.0 framework, as well as the renewal of operations in the region.

The development of competitiveness of the region, while maintaining and developing it as an attractive location for companies requires, co-operation between various stakeholders. Industry 4.0 can be applied as a framework for regional development. Universities have a major task to support competence development of relevant topics in various fields. In the field of manufacturing industry, the Industry 4.0 is increasingly relevant topic and the universities should identify their role to support local industry in its adaptation. 


\section{Industry 4.o as a framework for regional development}

The term "Industrie 4.0" was initially originated in Germany [1]. Industry 4.0 is a policy framework that defines and describes how new technologies should be adopted to renew manufacturing. The renewal is expected to bring major boost in competitiveness. It provides the framework for different kinds of policy initiatives. From the regional development perspective it can also be used as a guideline for steering research and development activities [2].

Industry 4.0 describes how machines, and other technologies adapted in manufacturing communicate with each other. The major importance is on a networked perspective, i.e., how different companies within a value chain communicate each other. The intention is such that computerized systems control and monitor physical processes. Industry 4.0 takes manufacturingrelated industries to the next level in adapting and utilizing digitization. In networked environment machines and physical objects are linked with each other. This allows decentralized production and real-time adaptation to the changes on the level of demand in the future [2].

The characteristics of Industry 4.0 is that it promotes computerization of manufacturing. Industry

4.0 is closely linked to Cyber-Physical Systems (CPS) [3]. They can be defined as transformative technologies which manage interconnected systems between its physical assets and computational capabilities [4]. We are increasingly using the concepts of the Internet of Things, the Internet of Everything and the Industrial Internet. The widespread adoption of information and communication technology (ICT) is increasingly accelerating and blurring the boundaries between the real physical world and the virtual one. The linkage is becoming increasingly smart [5].

Industry 4.0 is made possible through the development of the industrial Internet of Things [4]. New ICT-related technologies make Industry 4.o development possible and give opportunities to re-engineer value chains and create new business models. Internet of Things (IoT) is one of the core technologies for Industry 4.o. The growth of connections brings the new possibilities and solutions for business. On the other hand, exponential growth brings also new challenges for education, R\&D\&I, and regional development activities. The exponential growth of IoT connections indicates the birth of new business models and new kind of business environments. This "smartness" requires greater connection and collaborations. This is where the "explosion" of platforms and ecosystems is occurring. An attempt to connect the Internet of Things, services, data, and people need radical redesigns within industries and the participants to connect up this all. Presently, Industry 4.0 is more industrial driven, but this will change and broaden out [6]. 
Industry 4.0 is about increasing productivity and competitiveness. One perspective how this increase in productivity takes place is increase in the efficiency and speed of processes within a company or a value network. Basically, utilization of Industrial Internet makes it possible to optimize the activities and resource utilization in entire value network. Also, material and energy efficiency can be improved, which is important from the perspective of sustainable operations. Large sets of accumulated and real-time data can be applied to forecast or process development purposes. In addition, digitization provides opportunities for new start-ups and may create further prosperity [1].

Digitalization will bring new business opportunities and increasing competition. Companies are forced to renew their processes and activities, and at the same time restructure their business processes and models. Regions and areas are forced to plan and redesign services in their business environments as well. In order to see the development needs for attractiveness and welfare, but also to use the development resources in the best possible way, the key research questions related to this paper are:

1. How Industry 4.0 could be used as a framework for regional development?

2. What are issues affecting competitiveness of regions?

3. How structure and curricula of university could be renewed in order to support adaptation of Industry 4.0 in the region?

4. What issues to consider while applying Industry 4.0 to increase competitiveness of a region?

The changes created by Industry 4.0 are not only technological but also organizational [7]. More network-oriented operations are emphasized instead of a perspective of one single eco- nomic unit like one factory. The competence development activity, that is required to fully internalize Industry 4.0, is a major task. It should be implemented both on the societal level implemented for example by higher education institutions as well as on private enterprises. It is possible that productivity improvement perspective, which on the short to medium term, may lead to layoffs of workers regarding their current work positions is not necessarily welcomed by representatives of trade unions. However, on longer time frame, the competiveness of European manufacturingrelated industries is beneficial for all members of the society [1]. 


\section{Adaption of new technologies supporting Industry 4.o}

It is assumed that European manufacturing industry has to radically renew itself. Industry 4.0 provides guidelines on how to make this renewal ambition a reality. The adaptation of new technologies that can be interconnected provides major opportunities. While large-scale utilization of sensors that are connected by wireless networks as well as further adapting robotics provide potential to gain major leaps in productivity. Analytical methods that can be utilized on big data provide further insights on managing a network of producers and suppliers. Mass customization becomes a reality. The overall productivity increase is due to increased speed, improved quality, better utilization of existing resources, and so on. However, the manufacturing firms should be prepared to make required investment on both hardware (equipment and computers) as well as on software (competence development and applications) [8].

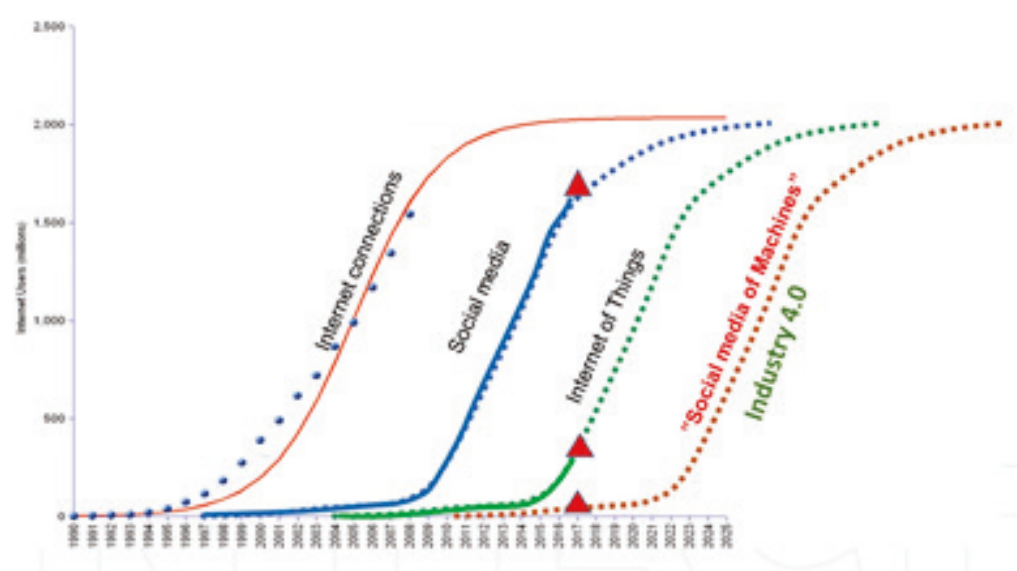

Figure 1. Rapid adaptation of new internet-related technologies.

Digitization is an increasingly relevant option while companies are trying to renew them- selves and their operations to remain competitive. However, digitization is not only a short- term project; it is a long term transformation that should be lead. The leadership perspective is very important in this change management initiative. Such technologies like cloud computing, wireless networks, and big data can be adapted. However, the main question remains, what changes are about to happen in our industry or value network and how applying digitization makes it possible to remain competitive and even further increase competitiveness.

The development of new technologies not only causes major changes and transformations, but also provides plenty of opportunities for exploitation of sustainable, residential, and residential-oriented urban centers and environments. The subscriptions to the Internet (IoT) alone will rapidly multiply in the years to come. This development affects traffic, travel chains, housing for commerce, welfare, healthcare, tourism, services, industry, etc. This development 
of new Internet-related technologies described in Figure 1 places urban development and development principles into a new perspective.

Training, development, innovation, and testing can no longer take place in a separate and closed laboratory environment, but to be able to create sustainable innovations education and development activities must be brought into an operating environment where residents, non- governmental organizations, political decision-making, civil servants, and students meet with regional development and different disciplines. The urban infrastructure is a part of the innovation-based ecosystems of different actors that produce new innovations at their interface.

\section{Competitiveness of regions}

Private organizations are doing their best to be more profitable and they are open to new ideas. That is why companies are actively starting to use new technologies and trying to find the most suitable business environment for their locations. At the government, region, and town level, the situation is quite different. Their task is not to make business, but to develop good and fruitful business environments for companies. Building infrastructure, providing a skilled labor force, etc., have been their main tasks.

By identifying the key factors for the Industry 4.0 related renewal, we will find different fac- tors, i.e., "levels." These are described in Figure 2.

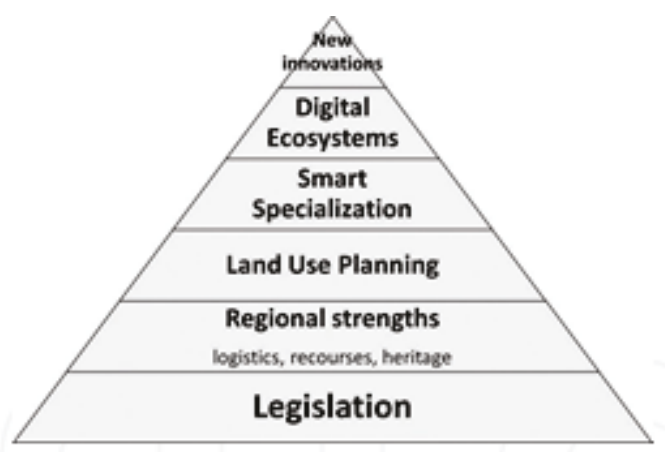

Figure 2. Factors affecting Industry 4.0 related renewal.

\subsection{Legislation}

Legislation is the very first level that we can see as the driver of development. At this level, we should understand that legislation should not be considered as an actor, which regulates/ limits (actions), but legislation makes new kinds of business possible and supports business development. Generally, we can understand that legislation gives "the rules of the game" and this way makes 
business environments more predictable with less business risks. Legislation also gives the framework for operations like recycling, land use, and new business models, but also taxation decisions might encourage new businesses. EU legislation gives the framework for legislation but still there is national legislation, which steers local business and industry.

\subsection{Land use}

We have industrial/logistics areas where companies are located. Usually, the industrial areas have developed and profiled themselves based on the strengths in the local region like logistic connections, population, energy, raw materials, knowhow at universities, skilled labor force, and so on. The question will be: how should we plan land use (business/logistic areas) so that companies would be able to create a fruitful business ecosystem, efficient material use (circu- lar economy), and minimize logistic expenses. This is usually a long process and the steps are not known accurately.

\subsection{Regional strengths}

We have industrial/logistics areas where companies are located. Usually, the industrial areas have developed and profiled themselves based on the strengths in the local region (like logistic connections, population, energy, raw materials, knowhow at universities, and skilled labor force).

\subsection{Enterprise ecosystem}

There are clear indicators that short distances will improve co-operation between companies. In the case of material and economic efficiency, short distances give savings in logistic expenses.

\subsection{History}

Every region and business has its own history and traditions, which makes it challenging to introduce new ideas makes it more difficult to manage change.

\section{Renewal of university structure and curricula to support adaptation of Industry 4.0 in the region}

One important role for universities is to support enterprises by applied research and creation of research and learning environments for continuous piloting of new technologies and preparation of new business models on Industry 4.o. It is not self-evident that representatives of government, enterprise, and universities collaborate with each other. It would be beneficial to support regional development while building up competence through shared projects and development activities. Digitization provides a large variety of opportunities. The 
ques- tion remains are we competent enough to utilize these opportunities. A close co-operation makes it possible to build a shared vision, which guides the further development work. This is important so that all the existing and available development resources could be aligned.

Quite often, it is expected that public sector organizations take care of the development of infrastructure and business environments. However, it is possible that the public sector organizations are not aligned with each other. Some of them may represent national perspective, while some are have a more local orientation. Also, there may still be other organizations, whose duty is to develop business environment. All the layers and activities should be along the same line, support each other, and be sustainable in order to get the co-operative environment to function efficiently. In a rapidly changing operational environment, a clear and commonly understood vision is required.

Industry 4.0 and Internet of Things are new topics; and both enterprises as well as universities have a little experience on what kind of real benefits they may bring. Co-operation between private enterprises and universities has potential, but still many universities as well as companies are just taking their initial steps on this arena. Various areas of collaboration do exist both on a national as well as on an international level. User-driven innovations show lots of promise, and therefore universities should try to identify the real market or real users for the potential innovations. Companies themselves could serve as field labs. One challenge is the confidentiality of information. This should be respected while promoting co-operational learning on various aspects related to Industry 4.o. To be able to reveal the full potential of enterprise-university partnerships, the interaction should take place on all levels. Being able to help the other partner to achieve their goals is beneficial for all. Longer-term development projects require high quality and in-depth roadmaps that should be developed collaboratively. This increases trust and commitment for long-term co-operation. Concrete cooperation project could emerge on various research projects, thesis work on both undergraduate and graduate studies and so on. Different kinds of experiments and measurements related to them could be started. It is important to succeed in benefiting multidisciplinary competence and sharing information sharing openly.

The vision and approach are based on the need of regional clusters and the strengths of a region (e.g., logistic, university, natural resources, etc.). Industry 4.0 development can be seen as a smart utilization of digitization, which has European level comparability to European development in all key clusters.

Contents of education and training will be designed so that content will respond the future needs. Learning will take place in "real world" environments (field labs), which gives faster cycle time for development activities and implementation. This is the way, how to ensure the birth of new innovations and the renewing the businesses and organizations. In universities, engineering students among others should be prepared to meet the demands of Industry 4.0 in order to be able to operate in future employment domains [9]. However, 
Industry 4.0 should not be linked to the competence requirements of only engineering students and thus future engineers. It is probable that Industry 4.0 affects largely the whole society, and therefore all the university students should be somehow involved with various perspectives of Industry 4.0.

Most regions do not have a strategy or analysis on aligning regional development and digitization. Häme region of Finland is designing its new strategy "Smart Häme" to respond the challenges of digitization and to be the part of Digital Single Market (DSM). Based on that, the focus is to increase the know-how on how to successfully apply digitization on Häme region. After a Smart Specialization analysis, five key ecosystems (clusters) were identified. These were expected to be the most critical for the development and attractiveness of Häme region (see Figure 3). These are the ecosystems, which also should have special attention and resource allocation, in development: "Smart Agriculture," "Smart City," "Smart Factory," "Smart Well- being," and "Smart Defense." The evaluation criteria, which were used to select the ecosystems in order to prioritize the development activities and resource allocation, were: size, know-how, importance, and versatility of the identified ecosystems.

\section{Smart Specalisation in Regions}

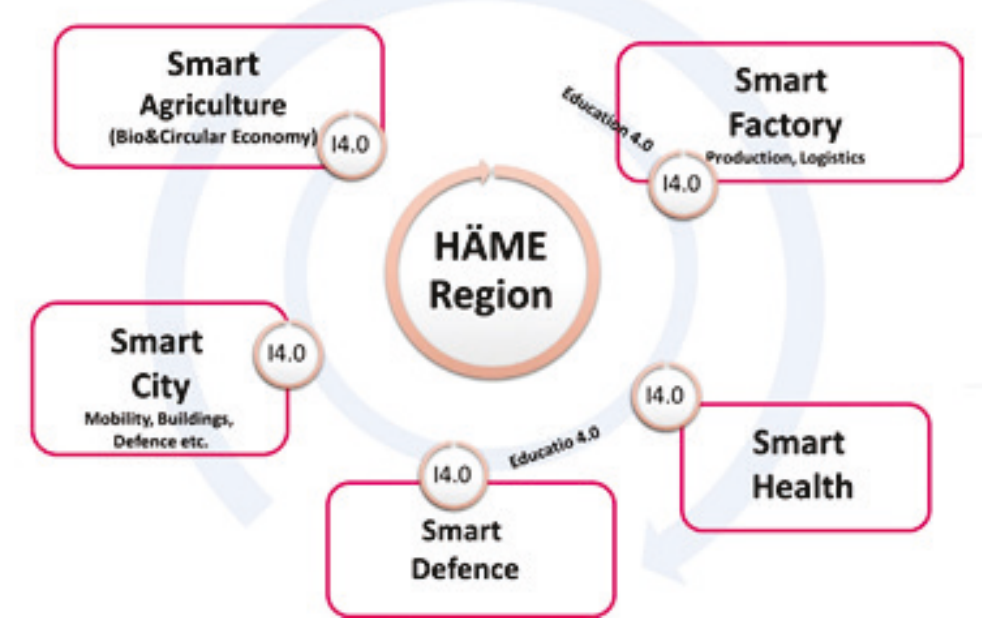

Figure 3. Häme region clusters/"Smarts.”

"Smart Agriculture" was considered to be the strongest and most advanced, because of food processing industry, agribusiness, large education, and strong R\&D activities in the region "Smart Agriculture" includes both, BioEconomy and Circular Economy (bio) activities in the region.

"Smart Health" is the biggest expense in the cost structure of public services. Also, the amount of increasing elderly people and demand for better services emphasize a strong need to utilize the various opportunities of digital services. There are also many equipment and service providers in the region. 
"Smart City" was also considered to be one of the key elements to improve the competitiveness of the region. There has been a clear understanding that digitization will change the planning of cities and the services in a city. The majority of services are probably in the densely populated urban areas in city centers. In Häme region "Smart City" includes also issues related to tourism, "Smart Mobility," "Smart Buildings," and "Smart Security."

"Smart Factory" has not been traditionally linked with services at all; but when we take a closer look at manufacturing industry, we will notice that lifecycle services might even play a bigger role than the production itself. Also, modern supply chains in the manufacturing industry have a strong and large service component. Regional development point of view is important to see that manufacturing itself creates new innovations and services.

The Smarts in the region and the ecosystemic choice to develop them are based on the region's own choices and intent. When defining the smarts, at least the following things should be taken into consideration: the strengths of the region, the competence (students and universities), the size, the intent, the development prospects, the history, the inheritance, the logistical position of skilled labor, prospects, and trends.

It is also important to understand the supporting nature of knowledge-intensive services in an increasingly digital world. This would better able the regional authorities and developers in co-operation with other actors to support the emergence of innovative ecosystems. Each smart must create its own "I4.0" renewal program, which creates a common vision, strategic steps forward and integration with the existing network organizations. Figure 4 illustrates how the selected smarts are linked to university's faculties (schools) and research units.

Industry 4.0 focuses on the fourth major transition phase in an industrial partnership covering all industries and areas of life. The fourth stage of the transition is digitality and the development of information technology. Industry 4.0 provides a framework for development, development of architecture, and standardization, and hence functional compatibility. The development of Smarts (clusters) is based on a multi-disciplinary know-how, therefore universities must support development work in all the sectors they are implementing academic degree programs. The following topics ought to be taken into account while renewing university's structure and curricula.

\subsection{Transdisciplinary approach}

A transdisciplinary approach to research enables multidisciplinary outlook and understanding phenomena from various perspectives. This makes it possible to study complex systems and their interactions. 


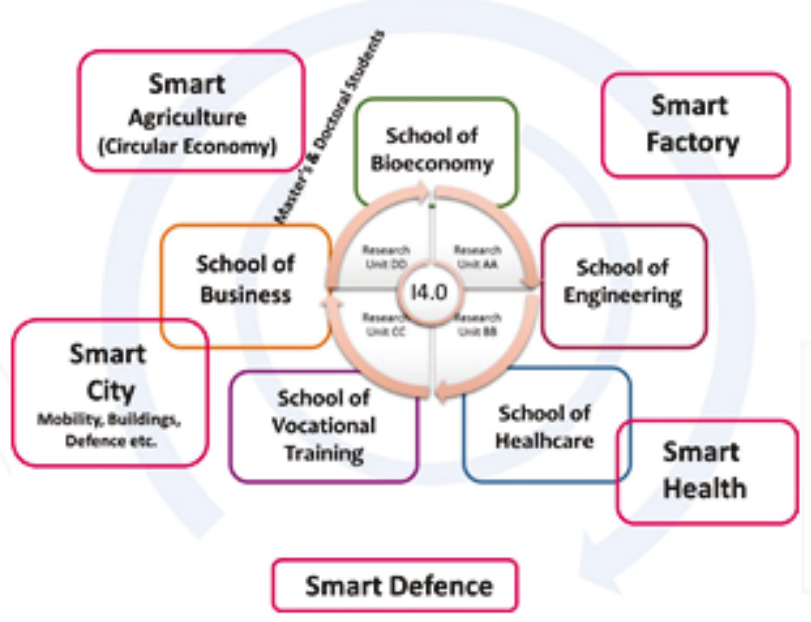

Figure 4. Integrating regional Smarts and university structure.

\subsection{System design management}

Digitality, multidisciplinarity, and the growing speed of change will result in increasing complexity, which is why the need for knowledge associated with managing complexity needs to be taken into account in education and development.

\subsection{Smart specialization}

Digitization provides the ability for data collection, rapid transfer, and processing. Various activities create new kinds of networks around them. For this reason, entities should be considered as digital ecosystems, which form efficient value chains and thus support creating new customer-focused products and services.

\subsection{Field labs}

The real-life learning environment is based on training, research, testing, and piloting environments. Multidisciplinary, complex, and fast changing things need "real-life" environments, where new things can be learned, adapt rapid methods for developing new products and services, and thus enable innovation to emerge.

\subsection{Innovations}

There are opportunities for new innovations that arise from different disciplines, customer interfaces, digital ecosystems, etc. 


\subsection{Organizational culture}

The introduction of new approaches will also require the systematic development of a new organizational culture and a strong vision of the goals regarding the renewal.

\section{Applying Industry 4.o as a framework for increasing competitiveness in the region}

Attractiveness from various perspectives is important so that region would be seen as an interesting and innovative environment. On the other hand, cities and public organizations (for example, hospitals, military bases, elderly houses, schools, parks, etc.) are using tax money for maintaining the welfare and provide services for people and organizations in the region. Based on that background, it would be justified that public organizations would be acting as "platforms" for different actors. This would allow testing their activities and products in "field labs" where education, research, and testing would take place in the same multidisciplinary environment.

We recommend that Industry 4.0 would be used as a transdisciplinary framework supporting a development of local service ecosystem. Since Industry 4.0 is a European concept and part of European platform, it is proposed that best practices will be benchmarked into European approach and experiences.

The key elements to designing the Local Service Ecosystem for Industry 4.0, are:

- "Smart development areas": to recognize the potential "smart" clusters on the region/area

- Vision: create the goal and vision for regional development based on "Smart" clusters

- "Field labs": make public sector organizations, cities, companies and universities to work together and create "real life learning" environment (field labs) in clusters.

- Education: renew education content so that it response the new ICTbased technologies that are needed in Industry 4.0 and transdisciplinary approach.

- Benchmarking: make benchmarking for the regions, which are like "Häme" and have al- ready taken the steps to adapt Industry 4.0 and to ensure compatibility. 


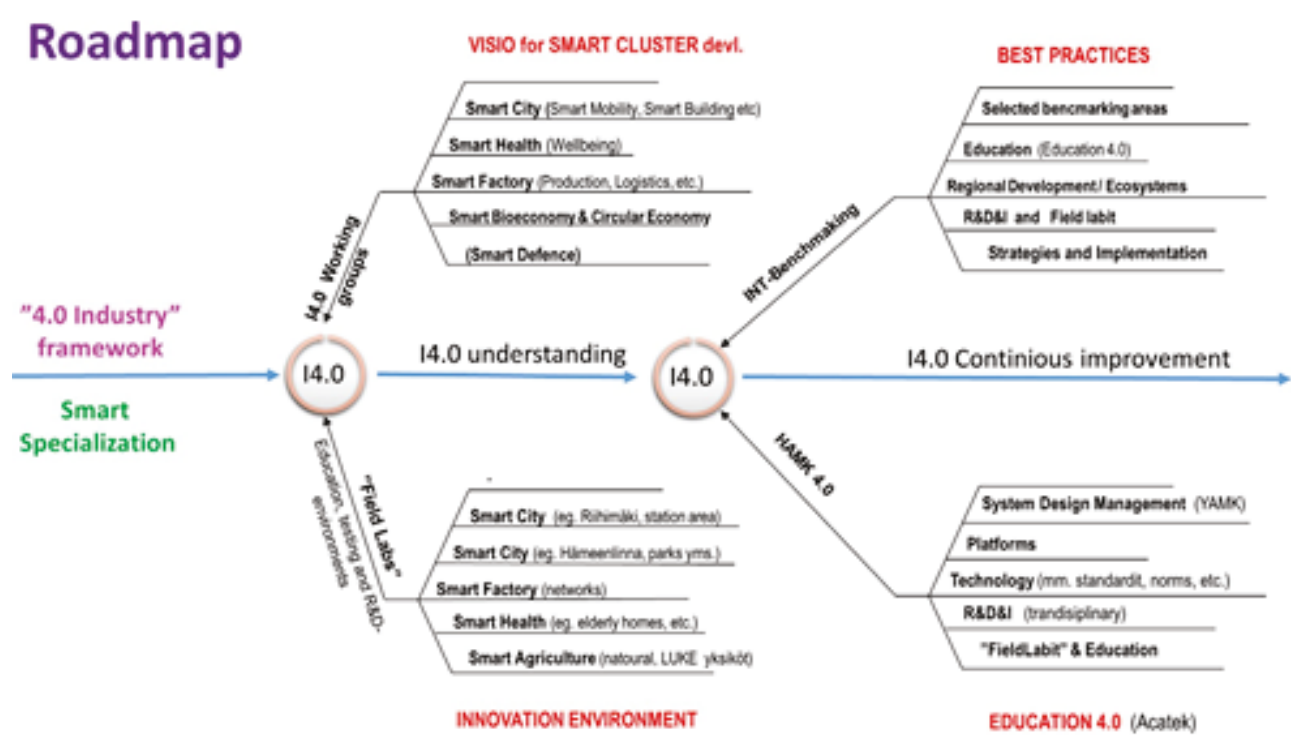

Figure 5. Steps to develop Industry 4.0 related services.

These elements are further covered in Figure 5. The core idea of the figure is that Industry 4.0 framework should be understood in the existing innovation environment so that smart clusters could be established. International benchmarking could be applied to identify best practices, which could be adapted to educational programs and field labs. In order to be able to adapt Industry 4.0 framework to education so that it could be called Education 4.0 the following issues should be con- sidered: system design management course should be introduced as a part of graduate studies. Technology platforms and implementation of transdisciplinary field labs should be introduced.

\section{Discussion and conclusions}

The principal idea behind this article has been to combine the principles of Industry 4.0 to value network thinking and digitization. Industry 4.0 is about creating significant impact and opportunities where business, technology, services, and innovation intersect. The aim has been to find a transdisciplinary concept supporting higher education, regional development, and business renewal in testing laboratories, while supporting and enabling new growth opportunities in the region.

That requires combining of various approaches. The main challenge is in the utilization of transdisciplinary knowledge and implementation work. The use of new technologies; includ- ing digitization and big data can capitalize on new opportunities. According to the experiences of conceptual development work, successful activity in Industry 4.0 is dependent on system- atic long-term development on the public sector. The essential topic is preparing of up to date platforms, which enables, controls, and support the operations and creates a 
business envi- ronment to apply approaches. There are several contributing technologies related to Industry 4.0 framework. This implies that there is a major emphasis on competence development, and shared learning to apply these technologies to support transdisciplinary regional development.

The practical implications for renewing a university so that it could better support the adapta- tion of Industry 4.0 are as follows:

1. Higher education institutions should provide education and support for the adaptation of Industry 4.0

It is important to give a relevant role for the higher education institutions to provide and sup- port a transdisciplinary approach to study services in a proper operating environment.

2. Research and learning environments in universities should be used to pilot new Industry 4.0 related technologies

One of the core roles for universities is to support enterprises by applied research and by creating of research and learning environments for continuous piloting of new technologies and preparation of new business models on Industry 4.o. At the same time, a local higher education institution's future areas of focus, challenges related to digitization, as well as profiling among other higher education institutions are taken into account.

3. Enterprise-university partnerships should be established

To be successful on new challenges of Industry 4.0 development, enterpriseuniversity partnerships have to be intense and main objective should be a shared learning. Long-term co- operation creates a background for new co-innovation and co-evolution.

Adapting Industry 4.0 framework as a basis for development activities is expected to provide not only an opportunity for remarkable competitive advantage for businesses, but also for regions.

\section{Author details}

Heikki Ruohomaa, Mikko Mäntyneva* and Vesa Salminen

*Address all correspondence to: mikko.mantyneva@hamk.fi Häme University of Applied Sciences, Hämeenlinna, Finland 


\section{References}

[1] Drath R, Horch A. Industrie 4.0: Hit or hype? [Industry forum]. IEEE Industrial Electronics Magazine. 2014;8(2):56-58

[2] European Parliament. Directorate-General for Internal Policies. Industry 4.o. 2016. Available from: http://www.europarl.europa.eu/RegData/etudes/STUD/2016/570007 / IPOL_STU(2016)570007_EN.pdf

[3] Haverkort BR, Zimmermann A. Smart industry: How ICT will change the game! IEEE Internet Computing. 2017;21(1):8-10

[4] Lee J, Bagheri B, Kao HA. A cyber-physical systems architecture for Industry 4.0-based manufacturing systems. Manufacturing Letters. 2015;31(3):18-23

[5] Deloitte. Industry 4.o Challenges and Solutions for the Digital Transformation and Use of Exponential Technologies. 2014. Available from: https://www2.deloitte.com/ content/dam/Deloitte/ch/Documents/manufacturing/ch-enmanufacturing-indus- try-4-0-24102014.pdf

[6] PWC. 4.o Industry: Building the Digital Enterprise. Global Industry Survey. 2016. Available from:

https://www.pwc.com/gx/en/industries/industries-4.o/landingpage/industry- 4.0-building-your-digital-enterprise-april-2016.pdf

[7] Lasi H, Fettke P, Kemper HG, Feld T, Hoffmann M. Industry 4.o. Business and Information Systems Engineering. 2014;6(4):239-242

[8] European Parliament. Briefing 4.o Industry Digitalization for Productivity and Growth. 2015. Available from: http://www.europarl.europa.eu/RegData/etudes/BRIE/2015/568337/ EPRS_BRI(2015)568337_EN.pdf

[9] Schuster K, Groß K, Vossen R, Richert A, Jeschke S. Preparing for Industry 4.0-Colla- borative virtual learning environments in engineering education. In: Automation, Communication and Cybernetics in Science and Engineering 2015/2016. Cham: Springer International; 2016. pp. 417-427 


\section{PUPLICATION C}

Publication C. Ecosystem- based development on managing digital transformation Authors: Heikki Ruohomaa, Vesa Salminen

AHFE 2019 the Washington Hilton, Washington D.C. USA, July 24-28, 2019. 


\title{
Ecosystem- Based Development on Managing Digital Transformation
}

\author{
Heikki Ruohomaa ${ }^{1}$, Vesa Salminen ${ }^{1}$ \\ ${ }^{1}$ Häme University of Applied Sciences, Hämeenlinna, Finland \\ heikki.ruohomaa@hamk.fi,vesa.salminen@hamk.fi
}

\begin{abstract}
Digitalization, megatrends, the new opportunities offered by technologies have caused societies to break through towards the fourth industrial transformation. It will change the whole society and its structures alongside the business. All societies, not just corporations, but also cities and regions, have to prepare for the change caused by digitalization. That challenges also traditional organizational structures. This requires a new type of business operation and organization. As a nation, Finland is adopting an ecosystem approach to resource-efficient orientation, avoiding mutual competition and increasing rapid innovation activity. Agile implementation of new issues is essential in different ministries. The national goal is to be the leading country in the exploitation of digitalization. Cities are responding to the rapid development of society and are moving from traditional organizational structures to ecosystem development and building their own network to involve in developing new operations. While cities largely receive their own funding as taxes, development and change management must be considered in the same way as in businesses. A key measure of efficiency is the improved service and achieved cost efficiency. The article examines the transition to ecosystem-based development of the Hämeenlinna city on the Finnish Growth Corridor.
\end{abstract}

Keywords: Ecosystems $\cdot$ digitalization $\cdot$ management of change $\cdot$ smart city

\section{Introduction}

All societies, not just corporations, but also cities and regions, have to prepare for the change caused by digitalization. That challenges also traditional organizational structures. This requires a new type of business operation and organization.

To keep competitive edge town and regions are forced to review their visions and strategies. This way leaders are extending their value proposition multidimensional by creating strong engaging environment, co-innovating and collaborating with their partner and this way to create integrated new attractive business environments and services for inhabitants. Increasing complexity challenge organizations to execute profitability in continuous change of new technology.

OECD Recommendation on Digital Government Strategies [1] outlines the political imperative for improving the efficiency, effectiveness and governance of public services design and delivery through digitalization.

The move towards new ICT based technologies will happen unexpected fast including exponential growth of data. That is the reason why it is essential to understand the challenges of change and have strategic view, identify the key elements and see the new opportunities in all level of society development. Increasing complexity needs new approach on organization structure, but also education and research in order to manage fast change and ensure the best possible implementation. 
This article describes ecosystem-based development at Hameenlinna town, by using its strengths, but also learning new skills. Objectives are to improve the competiveness and vitality its business environment and town services as well.

\section{Theoretical Background}

New technology will change the business environment and society in order to be able to safe scarce resources, manage fast change, make better innovations and have proper implementation, so there will be need for new kind of organization structures.

As a nation, Finland is adopting an ecosystem approach to resource-efficient orientation, avoiding mutual competition and increasing rapid innovation activity. Agile implementation of new issues is essential in all businesses. The national goal is to be the first country in the exploitation of digitalization. It is necessary to think about strategy, relationships and value networks when building up digital ecosystems.

The business ecosystems may facilitate partnerships also with competitors. When there is interest to develop key technologies, they may join together and then later compete in the market. In a less-competitive ecosystem, groups such as a government, charity and a community group might collaborate on health or public policy because each entity has a shared interest and goal. “Digital business drives dramatic changes in organizations' business ecosystems, making them larger, more complex and essential to strategy. [2]

It is the management within the broader ecosystem, that will leverage fresh knowledge. Being able to apply context and domain expertise, worked through digital platforms and applied technology that focuses on co-creation, to deliver on the potential of new insights that are leading to innovation with a real difference. This collaborative "orchestration" will determine those that will emerge as winners within the industrial environment as they form unique competitive edges based on reliance, trust, and deepening partnerships. The digital platform facilities this but it is the value of the relationships that are connecting and exchanging value will decide the true winners and that requires ecosystem thinking. [3]

OECD report [1] outlines a systematic and consistent approach to achieving sustained public sector productivity improvements and more user-driven public services is required [1].

Industry 4.0 describes the organization of processes based on technology and devices autonomously communicating with each other along the value chain [4]. Industry 4.0 architecture takes account of the increased digitalization of various industries where physical objects are seamlessly integrated into the information network, allowing for decentralized production and real-time adaptation in the future [4]. Industry 4.0 is an umbrella term characterising digitization and integration of the whole industrial value chain [5]. 
Adapting Industry 4.0 framework as a basis for development activities is expected to provide an opportunity for remarkable competitive advantage for businesses but also for regions [6].

Innovation performance of an economy depends on how institutions/companies interact with each other as elements of a collective system of knowledge creation and use, and on their interplay with social institutions (such as legislation, norms and values) [7]. Keeble and Wever [8] have introduced their concept on how to create new firms during continuous regional development.

Emerging service ecosystems are fuelled by interconnecting service systems and digital technologies [9]. Miller and Langdon [10] introduce how to manage disruptive innovation by managing platform, product and process innovation in continuous cycles. It is important to see the world as a complex system and it must be understood that it is impossible to change one thing alone as everything is connected to something else [11]. The business ecosystem produces goods and services of value to customers, who are themselves members of the ecosystem. The member organisms also include suppliers, lead producers, competitors, and other stakeholders [12].

Every participant in ecosystem has an opportunity to participate on creation of innovations and value, which generally is produced on the boundaries of ecosystem stakeholders [13]. Business ecosystem can be born as group activity or a single company can create it by collaborative activities [14]. Co-evolvement between companies, cities, and universities bring solution to tackle on development activities together. It is possible to learn from each other, use best resources available and work together fast enough and resourcewise way on open and common platforms [15].

\section{Research Questions}

The importance of new technology, for the society, will continuously be more important, because of the availability and quality of services for inhabitants, but also based on expenses. The cities are needed to have a clear vision for development and organizational structure to manage fast change and continuous development work.

The main research of discussion are:

1.) Does digital transition lead to ecosystem-based development process

2.) Are there differences on private or public sector-based ecosystem development?

3.) How innovation and service network is constructing transdisciplinary ecosystem.

4.) How Industry 4.0 as business architecture is supporting the development of business-based ecosystem.

This article describe ecosystem- based development concept. Case study concentrates on Hämeenlinna city ecosystem environment; It provides an approach for new technology to bring a transition and coevolution on society. 


\section{Management of Change in Multidisciplinary and Co-Operative Environment in Smart City Development Work}

Digitalization and new technology change traditional business environment and is a big opportunity to find out competitive advantage in new business. Universities and educators have a good opportunity and central task in supporting the growth of business on the area of digitalization and ecosystem-based development. The co-operation between enterprise and universities and government, is important to succeed in coevolution when building up cumulative knowhow in creation of solutions for digitalization by benefiting digitalization in it. It is also important to have a common vision and commitment to direct the local authorities and funding. Otherwise, the activities can splinter as small pieces.

Organization exists in multiple business ecosystems (figure 1). These business ecosystems are dynamic networks of entities communicating with each other to create value for participants. The challenge is deciding how your organization will survive and thrive in its ecosystem. The degree of openness within ecosystems is managed by strategies, common goals and shared interest. An ecosystem may be hybrid, private or public. Organizations often participate in a hybrid of public and private ecosystems. [2]

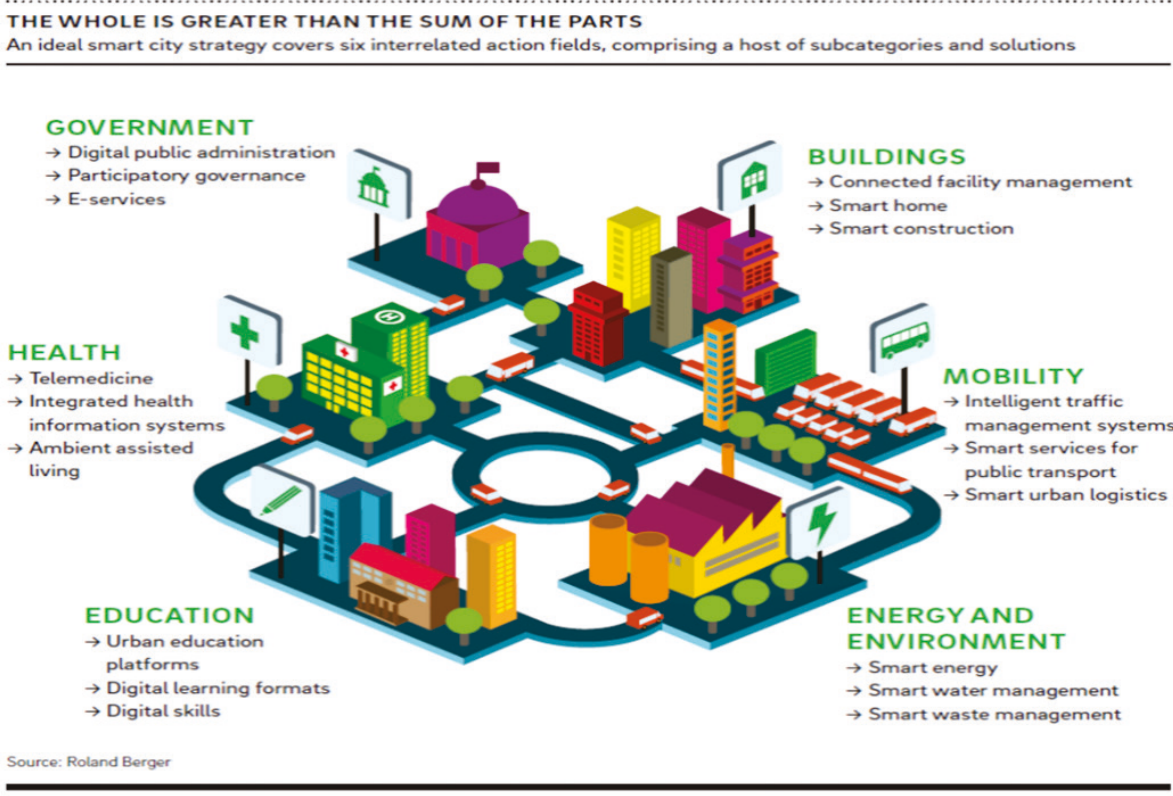

Figure 1. Cities have many ecosystems around it. (Source Ronald Berger)

One approach on the development of the ecosystems is co-evolution; where ecosystem member organizations or parts of the ecosystem evolve in alignment. An example of coevolution is a Digital Ecosystem and a Business Ecosystem evolution, which Moore (2003) introduces as the Digital Business Ecosystem (DBE). [16]

Ecosystems can co-evolve in a structural level in addition to species, roles and functions. 


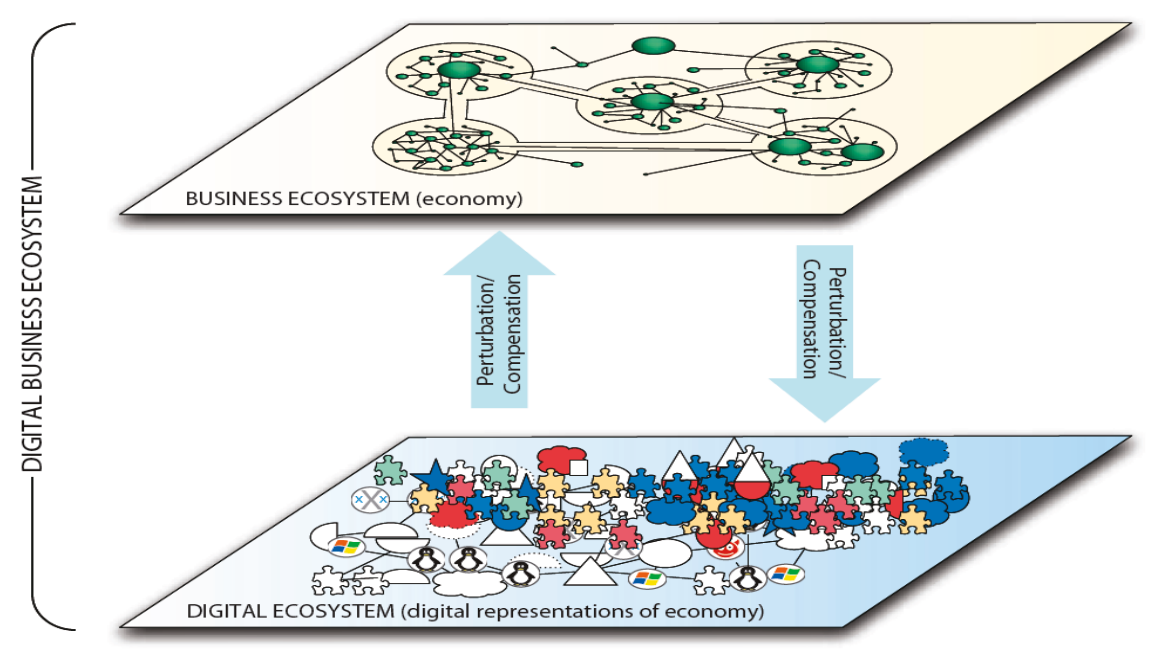

Figure 2. Digital Business Ecosystem (DBE Book, 2007)

Figure 2 illustrates a Digital Business Ecosystem structure where the business ecosystem and digital ecosystem are coupled to form a viable dynamic innovation ecosystem. The digital ecosystem influences enterprises, their social and business networks, and the business ecosystem affects the organisms of the digital ecosystem. [16]

Industry 4.0 can be seen as a framework for regional development [6]. In the field of social change, there is little awareness of Industry 4.0 outside the group of key stakeholders [4]. New ICT-related technologies make Industry 4.0 development possible and give opportunities to re-engineer value chains and create new business models- The growth of connections brings the new possibilities and solutions for the business.

Exponential growth of data brings also new challenges and indicates the birth of a new kind of business models. This "smartness" requires greater connection and collaborations. This is where the 'explosion' of platforms and ecosystems is occurring [17].

\section{Conceptual Model for Ecosystem-Based Development}

Cities are responding to the rapid development of society and are moving from traditional organizational structures to ecosystem development and building their own network to develop operations.

Fruitful cooperation requires common understanding and commitment. I requires also information and experience sharing. Cooperation have to happen on different levels operation, e.g forecasting and roadmap projects, development and research projects, developing learning environment for piloting and experimentation. All organization levels cooperation should be continuous process. Co-operation and learning together on 
real life environment is basis for innovations and continuous development. It is important to understand open information sharing and the benefits of multidisciplinary competence.

Figure 3 describes the implementation model of development towards ecosystem-based development process at Hämeenlinna city by benefiting value chain management, proper digitalization and data analysis/management. The key focus areas of development on increasing vitality of city area are future manufacturing, bioeconomy, smart services, tourism and events and smart town. The aim of digitalization is to increase effectiveness on planning and optimization. The objective of using and involving value partners is to support effectiveness of leadership and organization.

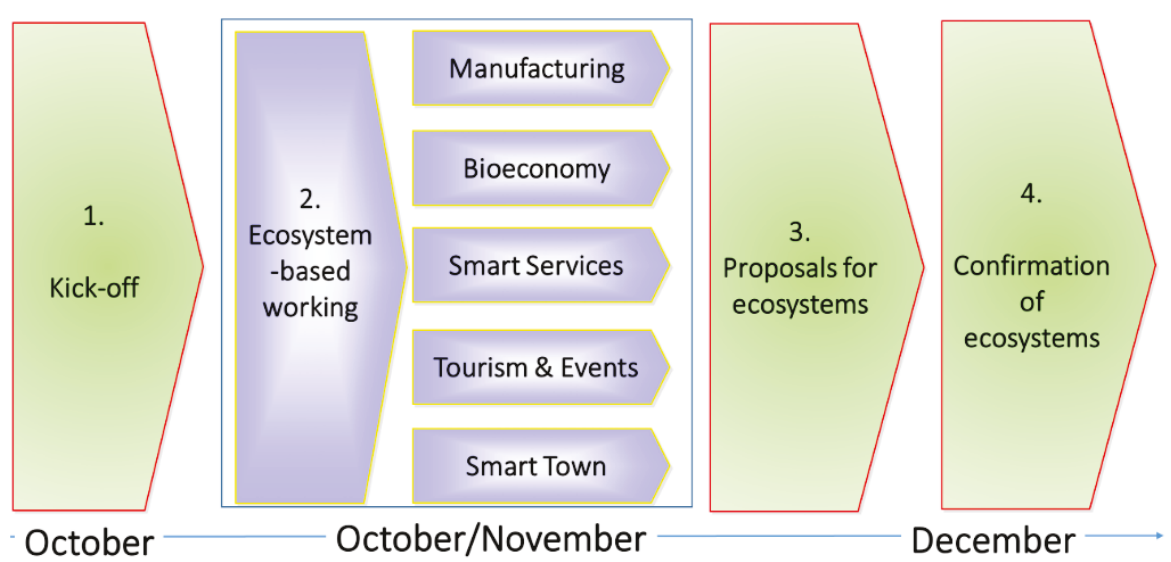

Figure 3 .

Proper implementation of ecosystem-based developing in Hämeenlinna town.

There have to be understanding about content and the process knowledge of customer site when applied research is been made. There have to right attitude and suitable skills to work in teams on distributed way with other experts in order to able to make valuable networks [15].

\section{Applying Ecosystem Based Development in Hämeenlinna Town}

While cities largely receive their own funding as taxes, in that case development and change management must be considered in the same way as in businesses. A key measure of efficiency is the improved service and achieved cost efficiency.

Hämeenlinna town is developing its strengths and competitiveness according its own strategy based on ecosystem-based development. Because of the vision and strategy, the authorities of town are motivated on long turn development related to the implementation of ecosystem- based development in the given focus areas. 


\section{Acta Wasaensia}

The development activities by Smart Service -research centre have been linked according "Industry 4.0" framework to ensure compatibility. At this moment "industry 4.0" gives more framework for development than given accurate orders or rules.

Industry 4.0 and digitalization can also be seen to attract new business to town. To ensure the implementation it is important to have an innovative atmosphere, so that customers/inhabitants/employees will join to the development and innovation activities. By engaging stakeholders, we can achieve more willingness to change, more commitment, opportunities for new ideas and start-ups. The development work will be done in the "real life" environments (factories, offices, hospitals etc.) by quick pilots.

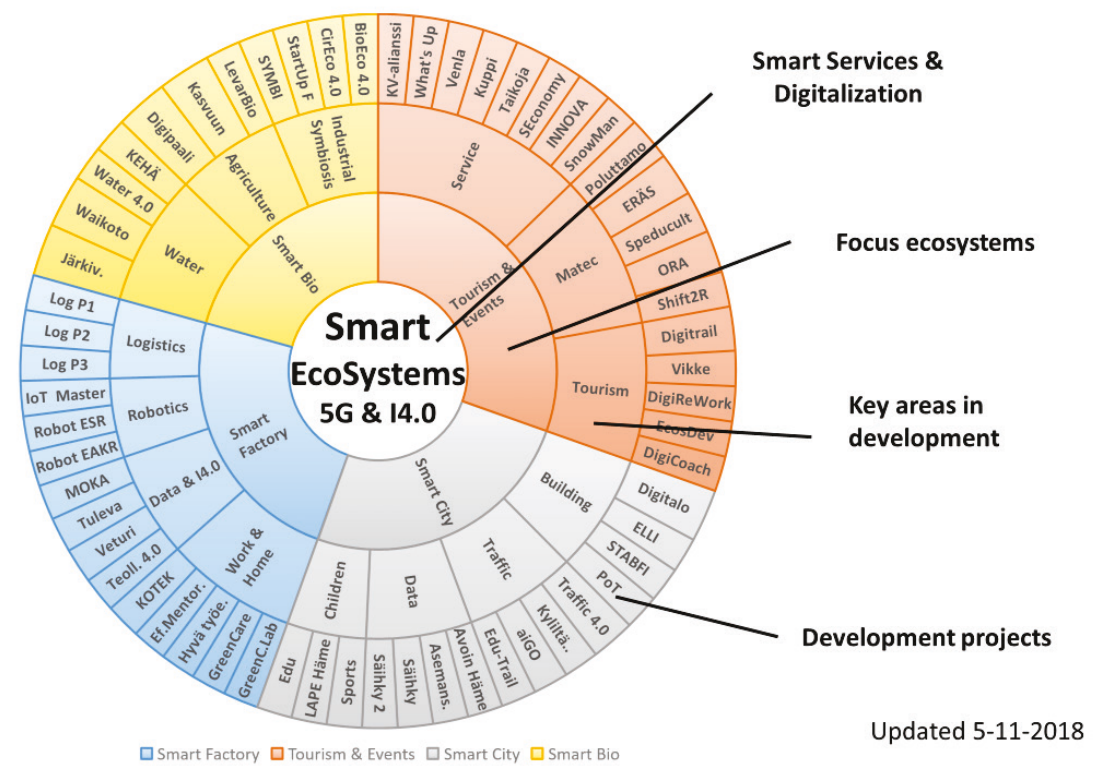

Figure 4. "The circle of Ecostystem-based development" in Hämeenlinna town by Smart Service- research centre at HAMK

The utilization of new ICT-based technologies requires new technical and multidisciplinary skills.

Education and reeducation are reducing resistance to change, speeding the implementation, and supporting the positive attitude to change, by building versatile knowledge. When education will take place in "real life" environment by pilots and quick trials, education is also fundament for innovation. Hämeenlinna town itself is willing to be the "real life" environment and that way provide platform for innovations and startups. 


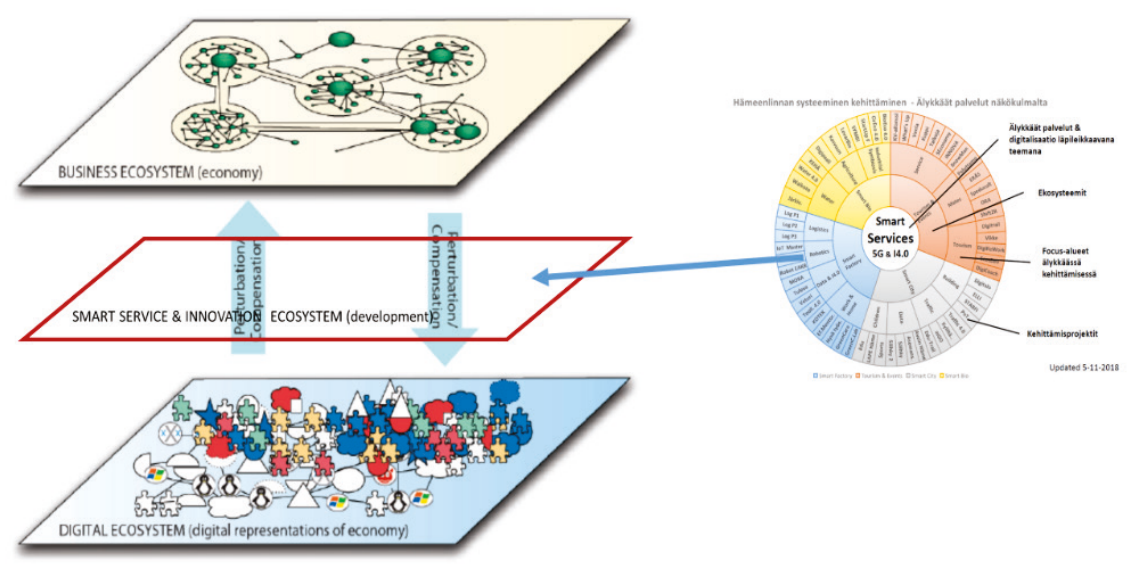

Figure 5. Research centre connect digitally to stakeholders inside ecosystems, but also connect ecosystems to each other's.

Smart Research-centre can so seem to be an important stakeholder in all ecosystem in Hämeenlinna, but it can also seem that Smart Research-centre is the key element that connect the ecosystem to each other and thus make fundament for the new innovations, which takes palace on the interfaces of different ecosystems.

\section{Discussion and Conclusions}

The ecosystem-based development plans of Hämeenlinna town has been analyzed in this article. The analysis describe, how Hämeenlinna is trying to respond the challenge of digitalization and develop its own competiveness and regional vitality. It has to manage fast change and also attract new business and inhabitants on the region.

The main idea, behind this article, has been also to understand the principles of industry 4.0 framework and digitalization on the ecosystem-based development on value network thinking. The town has created vision, objectives and focus areas commitment for long term development based on the smart specialization strategy.

The town has indicated in its ecosystem-based strategy the vision, intension and guidelines to all stakeholders. I has invited all stakeholders to common development work. To ensure the implementation of ecosystem-based development, the needed efforts will be made visible in all focus areas by having "a real life" environment pilots and quick trials. Hämeenlinna town ecosystem development work has deepened to relationship with municipality, industry, university and whole society. 


\section{Acta Wasaensia}

\section{Acknowledgment}

The authors wish to thank the Regional Council of Häme for financial support.

\section{References}

1. OECD Comparative Studies Report- Digital Government Strategies for Transforming Public Services in the Welfare Areas (2016). http://www.oecd.org/gov/digital-government/Digital-GovernmentStrategies-Welfare-Service.pdf (read 03.03.2018)

2. Dimensions of Business Ecosystems https://www.gartner.com/smarterwithgartner/8-dimensions-ofbusiness-ecosystems/

3. The Emerging World of Connected Industrial Ecosystems, January 10, 2018 by @paul4innovating

4. European parliament, briefing (Sept 2015) 4.0 Industry digitalization for productivity and growth $\mathrm{http}: / /$ www.europarl.europa.eu/thinktank (internet)

5. Deloitte (2015) Industry 4.0 challenge: Challenges and solutions for the digital transformation and use of exponential technologies.

6. Ruohomaa, H. Mäntyneva, M., Salminen, V. (2018) Renewing a University to Support Smart Manufacturing within a Region. Digital Transformation in Smart Manufacturing-Book, Chapter 8, InTech -Open Science|Open minds.

7. Clarke, T., Chelliah, J., Pattinson, E., National Innovation Systems in the Asia Pacific: A Comparative Analysis

8. Keeble, D., Wever E. (2016) New Firms and Regional Development in Europe

9. Lusch, F. R.; Vargo, S. L.; Gustafsson, A. (2016): Fostering trans-disciplinary perspectives of service ecosystems. In: Journal of Business Research, vol. 69 (2016), August, pp. 2957-2963.

10. Miller W., Langdon M. (1999) Fourth generation R\&D: Managing Knowledge, Technology, and Innovation. John Wiley \& Sons Inc., Canada.

11. Sterman J. (2000), Business Dynamics: Systems Thinking and Modeling for a Complex World. The McGraw-Hill Companies, Inc.

12. Moore, James F. (1996). The Death of Competition: Leadership \& Strategy in the Age of Business Ecosystems. New York: HarperBusiness. ISBN 0-88730-850-3.

13. Iansiti, M. \& Levien, R. (2004) The keystone advantage: what the new dynamics of business ecosystems mean for strategy, innovation, and sustainability. Boston: Harvard Business School Press.

14. Järvi, K. (2013). Ecosystem architecture design: Endogenous and exogenous structural properties. Lappeenranta: Dissertation, Lappeenranta University of Technology. 
15. Kukkamäki, J., Ruohomaa, H., Salminen, V. (2018) Development of ICT Education in Digitalizing Business Environment. 5th international Conference on Quality and Innovation in Engineering and Management- ICPR-AEM, 25th-26th July 2018, Club-Napoca, Romania.

16. Innovation Ecosystems Initiative, http://www.digital-ecosystems.org.

17. Ruohomaa, H., Kantola, J., Salminen, V. (2018) Value Network Development in Industry 4.0 Environment, Book Chapter. Advances in Human Factors, Business Management and Leadership, Springer International Publishing AG

18. PwC report (2016) 4.0 Industry: Building the digital enterprise. Global Industry Survey 
116 Acta Wasaensia

\section{ORIGINAL PUBLICATION D}

Publication DC. Value Network Development in Industry 4.0 Environment

Heikki Ruohomaa, and Jussi Kantola, Vesa Salminen, AFHE 2017, Florida) 


\title{
Value Network Development in Industry 4.0 Environment
}

\author{
Heikki Ruohomaa $^{1}$, and Jussi Kantola ${ }^{2}$, Vesa Salminen ${ }^{1}$, \\ ${ }^{1}$ Häme University of Applied Sciences, Hämeenlinna, Finland \\ \{vesa.salminen, heikki.ruohomaa\}@hamk.fi \\ 2 University of Vaasa, Department of Production, Wolffintie 34, 65200 Vaasa, Finland \\ jussi.kantola@uva.fi
}

\begin{abstract}
We are moving towards fourth industrial revolution through the development of digitalization. Globalization, shortage on resource, change on purchase behavior, urbanization e.g. influence on new competitive situation in every industry segment. This causes as well remarkable change pressures and opportunities for most of the industry.

The development of competitiveness of the region as attractive and maintaining it continuously requires co-operation between actors and building up a Roadmap, how to do continuously and systematically small development steps towards the vision and start development activities according that.

This article introduces created development process and framework for regional Roadmapdevelopment for various industry segments in Industry 4.0 environment. It also analyses how the increase of digitalization influences on work environment. The most important is how the mindset of people and behavioral culture is possible to change. The introduced industry sectors are manufacturing industry and circular economy.
\end{abstract}

Keywords: Industry $4.0 \cdot$ Value Network $\cdot$ Digitalization $\cdot$ Transdisciplinary $\cdot$ Co-Innovation $\cdot$ CoEvolution

\section{Introduction}

Many observers believe that Europe is at the beginning of a new industrial revolution, considered to be the fourth such leap forward and hence labelled Industry 4.0. The ubiquitous use of sensors, the expansion of wireless communication and networks, the deployment of increasingly intelligent robots and machines - as well as increased computing power at lower cost and the development of 'big data' analytics - has the potential to transform the way goods are manufactured in Europe. This new, digital industrial revolution holds the promise of increased flexibility in manufacturing, mass customization, increased speed, better quality and improved productivity. However to capture these benefits, enterprises will need to invest in equipment, information and communication technologies (ICTs) and data analysis as well as the integration of data flows throughout the global value chain. [1] 


\section{Acta Wasaensia}

The role of Finnish manufacturing industry is not often to be the main contractor (OEM) but biggest potential is in acting as subcontractor (SME) in supplier network for big international main contractors and be as part of their value network.

Succeeding in future in global supplier network requires that operations of main contractors and subcontractors are connected effectively and seamlessly together. Value networks function by flexible and cost efficient way and evolve continuously according the needs of main contractor and global competition.

The development of competitiveness of the region as attractive and maintaining it continuously requires co-operation between actors and building up a Roadmap, how to do continuously and systematically small development steps towards the vision. It is also important to benchmark industrial case studies and field labs on various other regions and find the most successful ones (e.g.Germany, Sweden, Austria).

Subcontracting network of manufacturing industry has significant influence on wellbeing, activity and employment of regions and areas. That is the reason, why regions/cities/countries has to develop and secure the competitiveness of industry and society. In future, the most essential task is to engage the companies and other stakeholders on regions as part of the development of Industry 4.0 and form a functioning ecosystem for the development work.

This article will demonstrate that 4.0 Industry is not only the goal but also the means. It introduces a strategic concept, responsible business leadership, for utilizing responsibility as a business and innovation driver to facilitate the transition of industrial business towards the new service economy. 4.o Industry is creating significant impact and opportunities where business, technology and innovation intersect.

Digitalization is rapidly increasing and enterprises must find new ways to innovate for business advantage. Through digital transformation, the use of new technologies like cloud, mobile, big data, and social networks with increasing intelligence and automation enterprises can capitalize on new opportunities and optimize existing operations to achieve significant business improvement. The collection of enormous amount of scattered data, clustering it for analysis, visualizing it for decision making and using the selected data in new service development and execution is most important in the concept of responsible business leadership.

Häme University of Applied Sciences (HAMK) has a Smart Service-research center as dynamic breeding environment to create and execute, together with co-operation network, well-addressed research and development activities for regional and enterprise development needs. The research unit supports cross-sectorial utilization of digital technologies and service business development. The objective is also to offer development support for municipal, industrial and commercial organizations by creating new opportunities and responding on business transition challenges. The management of responsibility in value network and entire society is becoming an important business 
driver. Most of companies, which are moving towards service business, need new concepts to manage life cycle business on the responsible way.

Most companies do not have a strategy or analysis on aligning business to digitalization. Being green to achieve mitigation, clean to reach up to optimization and smart to manage the transformation is the integrated, evolutionary approach. 4.0 Industry is an opportunity integrator on the path. Integrating novelty with technology brings new opportunities for more responsible business models. The transformation towards digitalization business takes a long time and that is why it is important to fully understand the strategic concept, identify the key issues and harness the associated opportunities.

\section{Theoretical Background}

The term "Industrie 4.0" was initially coined by the German government. It describes and encapsulates a set of technological changes in manufacturing and sets out priorities of a coherent policy framework with the aim of maintaining the global competitiveness of German industry. It is conceptual in that it sets out a way of understanding an observed phenomenon and institutional in that it provides the framework for a range of policy initiatives identified and supported by government and business representatives that drive a research and development programme. [2]

Industry 4.0 describes the organization of production processes based on technology and devices autonomously communicating with each other along the value chain: a model of the 'smart' factory of the future where computer-driven systems monitor physical processes, create a virtual copy of the physical world and make decentralised decisions based on self-organization mechanisms. The concept takes account of the increased digitalization of manufacturing industries where physical objects are seamlessly integrated into the information network, allowing for decentralized production and realtime adaptation in the future. [2]

In the field of social change there is little awareness of Industry 4.0 outside the group of key stakeholders. Larger firms tend to be more positively disposed whereas unions remain cautious and have reservations. While a skills gap (as well as a gap in willingness) to adjust to the Digital Single Market exists, the skill requirements to adjust to Industry 4.0 are much greater. [2]

The physical world is merging with the virtual world. We are increasingly used to the internet of things, or the internet of everything and increasingly the industrial internet. They all are in the throes of digital transformation. The widespread adoption of information and communication technology (ICT) is increasingly accelerating the blurring of boundaries between the real physical world and the virtual one. The linkage is becoming increasingly Smart. [3]

New ITC based technologies make possible 4.0 Industry development and give opportunities to reengineer value chains and create new business models. Internet of Thinks (IoT) is one of the technological fundaments for 4.0 Industry. Growth of connections brings the new possibilities and solutions for business. Other hand 
exponential growth brings also new challenges for education, R\&D\&I and regional development activities. The exponential growth of IoT connections indicates the birth of new business models and new kind of business environments.

This "smartness" requires greater connection and collaborations. This is where the 'explosion' of platforms and ecosystems is occurring. To attempt to connect the internets of things, services, data, and people are needing radical redesigns within industries and the participants to connect all of this up. Presently Industry 4.0 is more industrial driven but this will change and broaden out. [4]

Eppinger [5] has discovered that the link between sustainability and innovation is commonly mentioned, but not commonly made. Chesbrough [6] points out there are a new logic behind open innovation, which embraces external ideas and knowledge in conjunction with internal $R \& D$. This offers a novel way of creating value. Miller and Langdon [7] introduce how to manage disruptive innovation by managing platform, product and process innovation in continuous cycles. Nidumolu, Prahalad and Rangaswami, [8] explain widely why sustainability is now the key driver of innovation. Salminen [9] has discovered that when new value for the customer is created in the form of a product or service offering and it results in sustainable innovation, it is essential to know whether there is also a transition into a new business model of circular economy. At the same time, the business innovation must be built on the essential business structures (operational systems, contracts, network structures, competence, etc.). Tammela and Salminen [10] introduce the interoperability concept through which common innovation of sustainable products and services can be accelerated by an open semantic infrastructure. The open innovation process requires the definition of interoperability in order to achieve a critical level of network dynamics to create new products and services. Skyttner [11] introduces new systems theory with self organization and evolution. Jamshid [12] introduces that system thinking is the art of simplifying complexity. It is about seeing through chaos, managing interdependency, and understanding choice. Concepts are important to explain chaos. Sanchez and Heene [13] have proposed an open systems model of firms. Improving of organizational competence also requires increasing managers' own cognitive flexibilities to imagine new strategic logics for creating and realizing new kinds of value-creating product offers and new ways of managing processes for creating and realizing new and existing product offers. Markopoulos and Vanharanta [14] have created the Company Democracy Model. It can be characterized as a multidisciplinary science, as it integrates many management (strategy, leadership, etc.), engineering (process knowledge, innovation), social (human resources, ethos, etc.), financial (marketing, extroversion, etc.) and other disciplines. The uniqueness of the model is its capability to integrate them all in a transparent way, making the execution sequence these disciplines to seem absolutely normal, reasonable and effective. The co-evolutionary spiral method in the model contributes towards the identification and achievement of the capacity, capability, competence, and maturity needed to turn knowledge into innovation. The model is structured in such a way that the method reflects the Co-Evolute methodology [15] and its application in organizational democratic performance. Evolute is an intelligent web-based system for managing human competences and organizational objects and capability in the world of business. Both 
organizational development methodologies (Co- Evolute and the Company Democracy Spiral Method) are directed towards the creation of an organizational knowledge based culture [16].

\section{Research Questions and Research Approach}

Digitalization will bring new business opportunities, and increasing competition. Companies are forced to renew their processes and activities and same time restructure their business models. As well, regions and areas have forced to plan and redesign again their attractiveness for new and existing business in their business environments. In order to see the development needs for attractiveness and welfare, but also to use the development recourses best possible way the key research questions are:

1. How to determine the implementation plan and roadmap for Finnish Growth Corridor to industry engagement on the approved Industry 4.0 European Growth Strategy

2. How education can updated to responds the need of new competition in exponentially growing digital environment

3. How to ensure the change and innovations in organizations.

4. How to define the roles of actors in regional development and "smart clusters"

5. How to start using the Industry 4.0 framework in continuous development

This article introduces a concept model for utilizing 4.0 Industry as a business and innovation driver to facilitate the transition towards the new Digital Single Market.

\section{Multidisciplinary and Co-Operative Environment}

Digitalization changes everything and is a great opportunity to find out competitive advantage in business. Universities of applied science have a good opportunity and central role in supporting the growth of business on the area of circular economy.

The co-operation between government, enterprise and universities is essential to succeed in co-evolution when building up cumulative competence in creation of solutions for Regional Development by benefiting digitalization in it. It is also essential to have a common vision to direct the local operation and funding. Otherwise, the activities can splinter as small pieces and do not form parts of the whole vision.

The development of business environments is understood to be the responsibility of public sector and government. Public sector is however multilayered (e.g. legislativenational- provincial- regional- municipal- areal). There are still other committees and operations, which have the duty to develop business environment. All the layers and activities should be along the same line, support each other and sustainable to get the cooperative environment to function efficiently. In rapidly changing operational environment, it requires clear and commonly understood vision.

The vision and approach are based on the need of regional clusters and the strengths of region (eg. logistic, university, natural recourses etc.). 4.0 Industry development will 


\section{Acta Wasaensia}

been seen as a smart utilization of digitalization, which has European level comparability to European development in all key clusters.

Development roles will be designed the way that roles are tested in region where development is ahead. That approach mean that Reginal level organization (HAME OWL) is taking responsibility about the common platform and development resource allocations for the clusters ("smarts").

Contents of education and training will be designed so that content will respond the future needs. Learning will take place in "real world" environments (field labs), which gives faster cycle time for development activities and implementation. This is the way, how to ensure the birth of new innovations and the renewing the businesses and organizations.
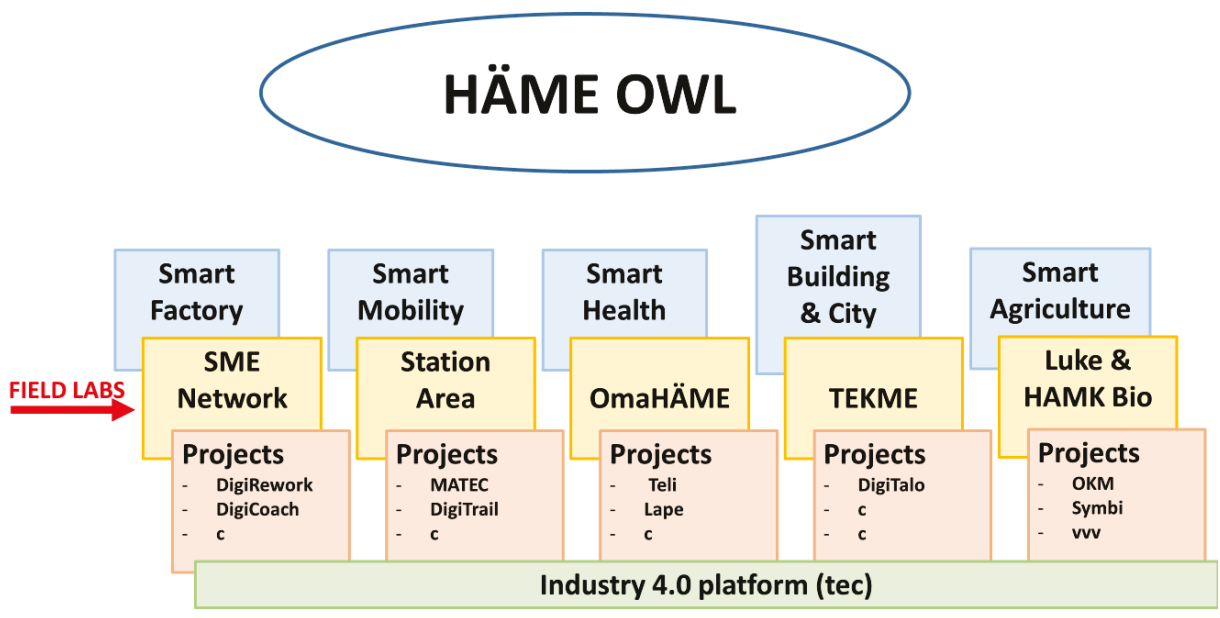

Fig. 1 Häme Region Cluster/"Smarts", field labs, future developmet projects and platform.

4.0 Industry and industrial internet can then be used when increasing the efficiency of processes. Industrial internet enables functional optimization of entire value network and increasing of use of material side flows (material and energy efficiency). It is possible to anticipate beforehand the disturbance situation of value network and their repair operations. Collected data from whole the value network can be used for its functional development or forecasting purposes. New entrepreneurship and new digital services can be created through digitalization activities. Industry 4.0 standard architecture can be applied for common framework, when starting business on circular economy.

In Figure 2, there is an example of technology oriented competence and solution creation on the smart clusters. It is essential to gather data from various sources and different processes. Automation system or sensor network (IoT) is creating data, which is gathered, clustered, analyzed and compare it with the data gathered earlier and then make 
decisions on how the optimize activities. To support this value network process it is important to have all type of experts in virtual network optimizing material, logistic and reuse of material. There can also be final customer experts in the same network.

The substance in the network is knowledge and capability, which is activated when the customer requirements are decomposed. In order to manage economical and technical risks the new innovation should be evaluated as a value for customer and network partners. Effective method of decomposing the requirements reveals precisely. Content management competence, organizational capability and human mental capability are in strong interrelationship. It is planned to parametrize each of the entities and turn as a questionnaire's. Evolute- system is thought to gather and analyze the knowledge needed.

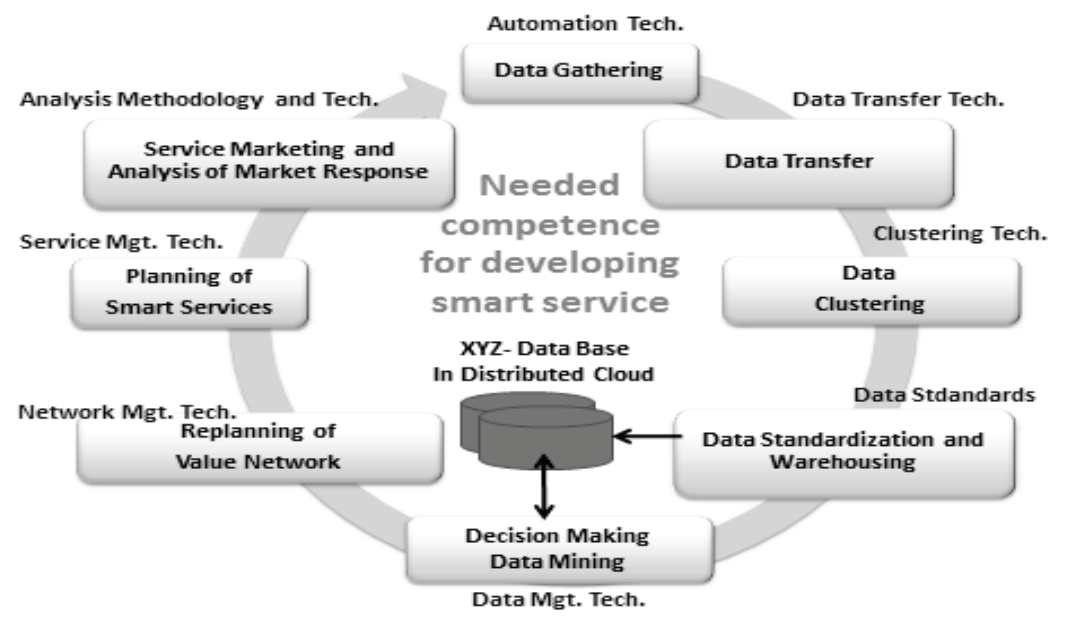

Fig. 2. Relationship of technology and competence using the data effectively

New ITC based technologies make possible 4.0 Industry development and give opportunities to reengineer value chains and create new business models.

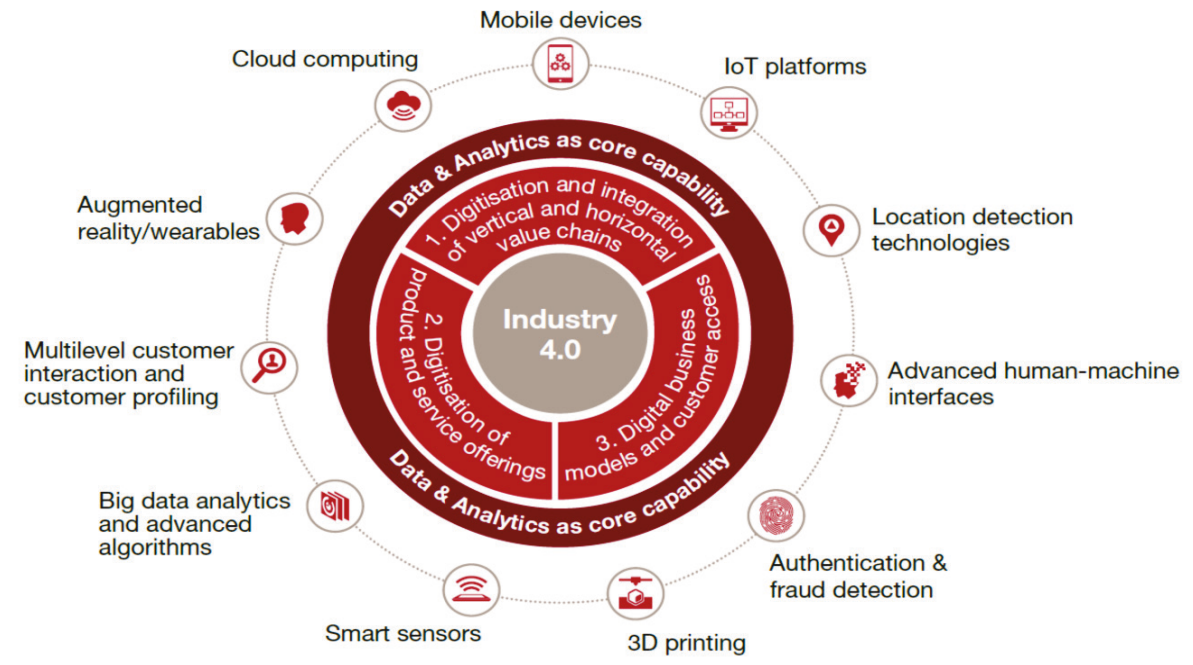

Fig.3. Industry 4.0 framework and contributing digital technologies [4] 


\section{Pilot (Case: BioEngineering (ICT))}

In order to develop its own knowledge and flexibility to response the demand of exponentially growing digitalization and transdisciplinary problems. Based on that development, HAMK has designed new program (BioEconomy Engineering ICT), with the idea, that it will be first pilot step to start implement 4.0 Industry concept in "Smart" BioEconomy Cluster and start learning process to make change toward 4.0 Industry also in other "Smart" Clusters and whole Häme Region.

Content of studies and learning method with the cooperation of industry are designed 4.0 Industry compatible.(BioEngineering DP is ICT programme for BioEconomy environment.)

\section{Pilot Case: BioEconomy engineer (ICT)}

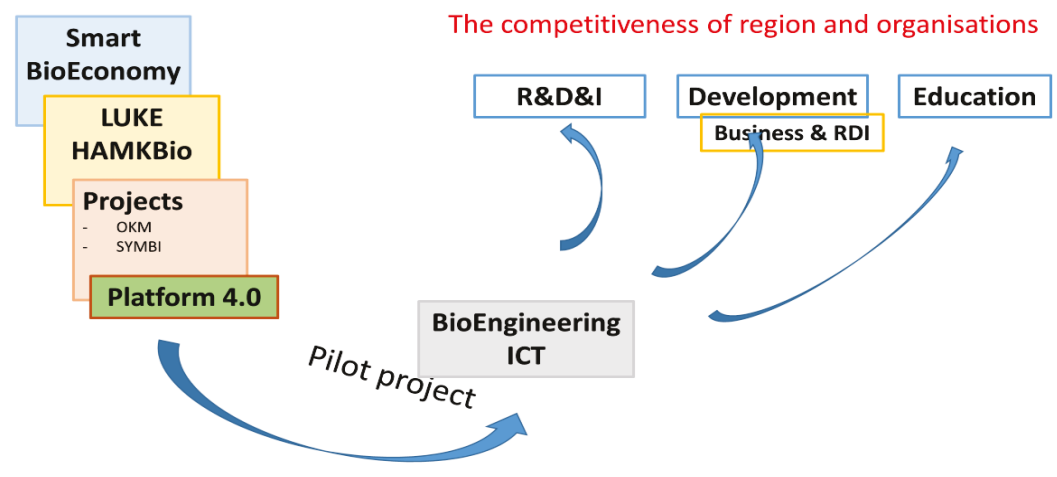

Fig. 4. The content of BioEngineering DP is planned so that it support the development of industry and region.

Education will take place in close cooperation with industry by doing projects by "resolving real life" problems. By this approach is possible to educate students to response to transdisciplinary problems, but also to speed the development in industry and region.

The every study module of degree programme is planned so that it will support regional development and R\&D\&I activities. This is considered to be very important to be able to find new innovations in company surface. In order to create unik organization culture many other degree programmes are involve and their cultures, not only because of their knowhow. 
Partly "R\&D-teams" will take care of a few study modules, in order to strengthen the content of new technologies in HAMK. R\&D-teams will operate over the study programme and faculty boarders and will participate actively human resource activities.

The study modules which are ran by "R\&D-teams" are like "Data Collection \& Visualization", "Data analytics and Clouds", "Service Design" etc.

Usability of this kind of "R\&D-teams are piloted in BioEngineering education".
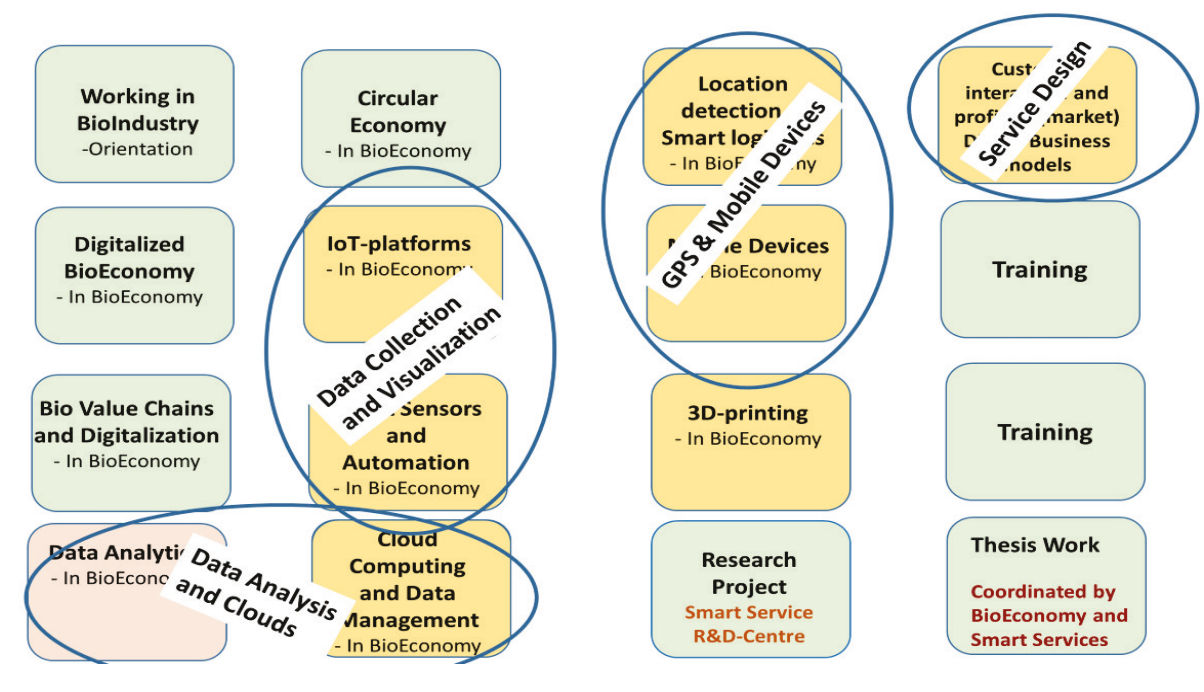

Fig. 5. The responsibility of "R\&D-teams"

When the "R\&D- teams have been develop and tested, the experience of teems will be utilized in other programs under redesign and other activities over the faculty boarders

Smart services research unit at Häme University of Applied Sciences supports industry, commerce and the society in digitalization and service development needs. The task of the research unit is to create and execute, together with co-operation network, welladdressed R\&D activities for the region and its' enterprises. The Smart Services research unit supports the utilization of digital technologies and service business development across sectors: similar solutions can be adapted in various lines of business.

\section{Benefiting Digitalization and Big Data Supporting Business Co- Evolution}

The amount of scattered and structured data around us is increasing dramatically. It is a great business opportunity to benefit that data in business purposes. Circular economy with interrelated bio and mechanical cycle consists of huge amount of data. The data of waste from one partner means material for the other partner. Understanding the value 
proposition in growing value networks is essential. Management and analysis of data coming from various sources is routed through data- to- service process in business coevolution of circular economy, Figure 6. Creation and optimization of new operational functions and responsible business co-evolution requires democratic innovation and decision culture.

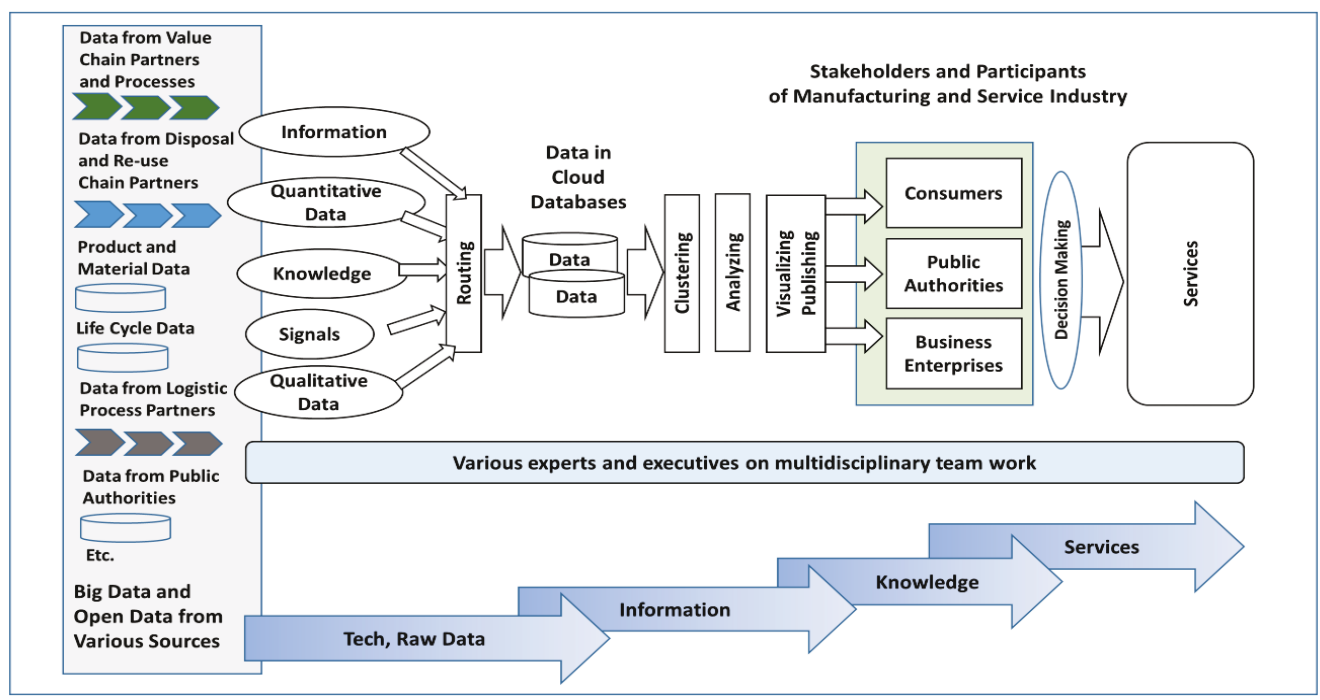

Fig. 6. From data to services process in business co-evolution

\section{Industry 4.0 - Conceptual Model for Adaptive Development}

4.0 Industry and industrial internet are rather new topics and there are few experiences on driving of benefit out of them both in enterprises and universities. That is why co-operation serves developing on collaborative way. Most of the innovations are created at customer interface and co-operative development on common platform, research and learning environment, is essential basis in succeeding on business co- evolution. Good co-operation requires management engagement, trust building, information, and experience delivering. It happens on various levels of operation; e.g. forecasting and roadmap-projects, applied research and development projects, on bachelor and masters' thesis works or creation of research and learning environment for experimentation and piloting. It is ought to be continuous on various organization levels. Co-operation and learning together on research and learning environment supplied by university is basis for new innovations and continuous development. Developing of superior competitive power through principals of circular economy is built by lean and digitalized value networks. It is important to succeed in benefiting multidisciplinary competence and open information sharing.

Häme region is designing its new strategy "Smart Häme"to responds to the challenges of digitalization and to be the part of Digital Single Market (DSM). Based on that, the focus is to increase the knowhow to digitalization on Häme region

Since 4.0 Industry is European concept and part of European platform, it is wise that best practices will be benchmarked into European approach and experiences.

The key elements to design the "roadmap" for 4.0 Industry, are: 
- to recognize the potential "smart" clusters on the region/area

- create the goal and vision for region based on "Smart" clusters

- make companies and universities to work together and create "real life learning" environment (field labs) in clusters.

- renew education content so that it response the new ICT based technologies that are needed in 4.0 Industry

- create approach that knowhow will increase and it will be distributed on region

- the role of "Hämeenliitto" as coordinator and allocating assets

- make benchmarking for the regions which are like "Häme" and have already taken the steps to adapt 4.0 Industry

Succeeding on 4.0 Industry co-innovation requires data-to-service management process and creation of adaptive multidisciplinary co-operation model for solution development. For research center to be capable to collaborate with industrial companies, it is important to know the overall capability of research and development unit. The experts making applied research with customers have to have content and process knowledge of customer site, they have to be capable to work in teams on distributed way with other experts in value network and have to certain collaborative skills to work together. In our article, we categorize the competence and capability on three layers: content management capability, organization capability and human competence and capability [16].

\section{Discussion and Conclusions}

Combining the principles of 4.0 Industry to value network thinking and digitalization of functionality of whole the network give opportunity for remarkable competitive advantage in business.

That requires combining of various theories but the main challenge is in utilization of transdisciplinary knowledge and implementation work. The use of new technologies; digitalization, big data, and social networks with increasing intelligence and automation enterprises can capitalize on new opportunities on and optimize existing operations to achieve significant business improvement on circular economy.

According the experiences of conceptual development work successful activity in 4.0 Industry is dependent on systematic long-term development on public sector. Essential topic is preparing of up to date platforms, which enables and controls and support the operation and creates business environment to apply new offering.

The important role for universities is to support enterprises by applied research and creation of research and learning environments for continuous piloting of new technologies and preparation of new business models on 4.0 Industry.

To be successful on new challenges of 4.0 Industry development, enterprise- university partnership has to be tight and main objective is common learning. Long-term cooperation creates background for new co-innovation and business co- evolution.

European community is preparing new legislation and directives, which are speeding up the development of Digital Single Market. Industry 4.0 as an industrial standard architecture has a remarkable role in preparing new functionalities on distributed value 
networks. The standard offers technical background and rules for implementation for digitalized circular economy.

Responsibility business leadership needs democratic innovation culture and coinnovation and co-evolution processes. This article introduces a concept of responsible business leadership. It also gives a concept on how to analyze co-evolution over the life cycle of business transition on "smart clusters" by using Evolute for managing human opinions and experiences and organizational objects on public- private- relationship and capability in executing responsible business leadership.

\section{References}

1. European parliament, briefing (Sept 2015) 4.0 Industry digitalization for productivity and growth http://www.europarl.europa.eu/thinktank (internet)

2. European parliament (2016), Study for ITRE Committee. 4.0 Industry IP/A/ITRE/2015-02 ipol stud

3. Deloitte (2015) Industry 4.0 challenges Challenges and solutions for the digital transformation and use of exponential technologies

4. PwC,(2016) 4.0 Industry: Building the digital enterprioce. Global Industry Survey

5. Eppinger S. (2010) How Sustainability Fuels Design Innovation. MIT Sloan Management Review, Fall 2010, Vol.52 No 1, Boston.

6. Chesbrough H. (2003) Open Innovation: The New Imperative for Creating and Profiting from Technology. Harvard Business School Publishing Corporation, Boston.

7. Miller W., Langdon M. (1999) Fourth generation R\&D: Managing Knowledge, Technology, and Innovation. John Wiley \& Sons Inc., Canada

8. Nidumolu,R., Prahalad, C.K., Rangaswami, M.R. (2009) Why Sustainability is Now the Key Driver of Innovation. Harward Business Review, September 2009.

9. Salminen, V. (2008) Management of Life Cycle Business Transition by Hybrid Innovation. Managing Innovation in Connected World, ISPIM 08, 14-17.12.2008, Singapore.

10. Tammela, J., Salminen, V. (2007) Interoperability concept supporting Network Innovation. Information Technology Entrepreneurship and Innovation (chapter on a Book), Publisher Group Inc., Hershey, PA, U.S.A, 2007

11.Skyttner, L. (2005), General Systems Theory: Problems, Perspectives, Practices. World Scientific Publishing, Singapore.

12.Jamshid, G. (1999) System Thinking: Managing Chaos and Complexity. A Platform for Designing Business Architecture. Butterworth- Heinemann, Woburn, MA, USA.

13. Sanchez, R. (2004) Understanding competence-based management Identifying and managing five modes of competence. Journal of Business Research, 57, p.518-532.

14. Markopoulos, E, Vanharanta, H. (2014) Human Perception, Interpretation, Understanding and Communication of Company Democracy. 14th International and interdisciplinary Conference of the Research Cooperation, Turku, Finland

15. Kantola, J., Vanharanta, H. and Karwowski, W., (2006), The Evolute System: A CoEvolutionary Human Resource Development Methodology. In the International Encyclopedia of Ergonomics and Human Factors. Karwowski, W. (editor), 2nd Edition, CRC Press, Boca Raton, Florida, USA. 
16. Paajanen, P., Piirto, A., Kantola, J., Vanharanta, H., (2006) "FOLIUM - Ontology for Organizational Knowledge Creation". 10th World multi-conference on systemics, cybernetics and informatics. Orlando,Florida, USA.

17. Salminen, V., Kantola, J., Vanharanta, H. (2015) Competence portfolio assessment of research and development center for regional development. 6th International Conference on Applied Human Factors and Ergonomics (AHFE 2015), Las Vegas, USA July 26-30, 2015 
130 Acta Wasaensia

\section{ORIGINAL PUBLICATION E}

Publication E. Regional Development in Modern Robotic Education on Industrial and Society context

Ruohomaa Heikki, Salminen Vesa AHFE 2018, USA. Orlando 21-24 July 2018 


\title{
Regional Development in Modern Robotic Education on Industrial and Society context
}

\author{
Heikki Ruohomaa $^{1}$, Vesa Salminen ${ }^{1}$ \\ Häme University of Applied Sciences, Hämeenlinna, Finland \\ heikki.ruohomaa@hamk.fi,vesa.salminen@hamk.fi
}

\begin{abstract}
Regions are facing a huge competition, to attract companies, businesses, inhabitants, students etc. and this way to improve living and business environment, which is rapidly changing due to the impact of digitalization.

Good living and business environment are considered to include good working places, governmental services, transportation connections and safe environment. In addition to this, regions and cities need also to improve their imago, which supports the attractiveness of the town or region.

In this article, the actions of the town and industry are analyzed. The town is developing its activities according smart industrial specialization by using its strengths, but also adapting new knowhow of digitalization to improve the overall competiveness of industrial environment and town facilities itself.

The purpose of this analysis is to identify the elements, which are important for developing the attractiveness of the town in the momentum of the digital change of society in industrial context.
\end{abstract}

Keywords: Robotics, Industry 4.0, transdisciplinary, smart specialization, regional development

\section{Introduction}

Several ministries in Finland have made a surveys and created perspectives and plans on exploitation of robotics in business and whole society. National alignments direct also generally the operation and strategic alignment of Universities and Research Institutes. Nevertheless, there is not a clear national alignment on regional development or research on exploiting robotics widely in Finnish society. Riihimäki town has raised robotization as one of the focus area on their own strategy for developing the competitiveness and attractiveness and for renewing the imago of town.

In order to sustain competitive advantage, cities and regions are expanding and renewing their strategies. By doing so, these leaders are expanding their value proposition multidimensional by concurrently creating strong potential through developing more competitive customer engaging environments, co-innovating sustainable services together with their partners, and collaborating to create integrated new sustainable business environments. Organizations today are facing increasing complexity to execute profitably on continuous digital business transition towards digitalization and robotization.

Through digital transformation, the use of new technologies like cloud, mobile, big data, and social networks with increasing intelligence and automation enterprises can 


\section{Acta Wasaensia}

capitalize on new opportunities and optimize existing operations to achieve significant business improvement. The collection of enormous amount of scattered data, clustering it for analysis, visualizing it for decision making and using the selected data in new service development and execution is most important in the concept of responsible business leadership.

The management of robotics in value network and entire society is becoming an important business driver. Most of companies, which are moving towards robotics, need new concepts to implement the possibilities of robotics and update the knowledge. Most companies or cities or organizations do not have a strategy or any analysis on aligning business to digitalization or robotization.

OECD Recommendation on Digital Government Strategies [1] outlines the political imperative for improving the efficiency, effectiveness and governance of public services design and delivery through digitization, as the three primary categories of political objectives, alongside the equally compelling imperative for innovative public service design and delivery, in framing the direction of transformation processes.

The transformation towards digitalization and robotization will happen in short time and that is why it is important to fully understand the strategic concept, identify the key issues and harness the associated opportunities in the all level of development.

Exploitation of robotics have to be approached on wide perspective as a part of whole society development, not just as technological solution. Those can be done inside individual enterprises without bonds to the surrounding society. Complexity raised by increasing digitalization requires new type of approach on research and education but also on regional development to manage rapid change and ensure rapid implementation. Exploitation of robotics is a wider issue than the ability of an individual organization to make robots available. Robotization is holistic exploitation of the strategic competitiveness of the region. It must be examined more broadly and multidimensionally. On this topic cities and regional development organizations play a key role.

This article introduces the activities of Riihimäki town and surrounding society towards smart specialization by using its strengths, but also adapting new knowhow of digitalization and robotics to improve the overall competiveness of business, society and education environment and town facilities itself.

\section{Theoretical background}

Digitalization and robotization are no longer a question of if, but of when, and to what extent it will affect a specific business sector.

OECD report [1] outlines that demographic composition in OECD countries is changing, modifying significantly the demand for services, and in many cases, the capacity to provide those services. Governments and cities are facing increasing expectations from 
users to deliver more innovative and responsive services, while dealing with strong pressures to consolidate public finances to remain globally competitive and to spur growth. In other words, a systematic and consistent approach to achieving sustained public sector productivity improvements and more user-driven public services is required [1]. The focus is on digitization of education, healthcare, and social care and protection services, including smarter use of well-proven assistive technologies. The new digital environment offers opportunities for more collaborative and participatory relationships across stakeholders to actively shape political priorities, collaborate in the design of public services and participate in their delivery, with the public value chain highlighting changes to public sector boundaries [1].

Smart robots for smart strategies [2] outlines the strategies to unleash the potential of the digital economy in Europe. Future product visions point to domestic robots of higher sophistication, capability and value, such as assistive robots for supporting the elderly, for helping with household chores and for entertainment [3].

Industry 4.0 describes the organization of processes based on technology and devices autonomously communicating with each other along the value chain [4]. Industry 4.0 architecture takes account of the increased digitalization of various industries where physical objects are seamlessly integrated into the information network, allowing for decentralized production and real-time adaptation in the future [4]. What is characteristics to Industry 4.0 is that it involves connecting products to each other. Industry 4.0 is closely linked to Cyber-Physical Systems (CPS) [5]. To be successful on new challenges of Industry 4.0 development, enterprise-university partnerships has to be intense and main objective should be a shared learning. Adapting Industry 4.0 framework as a basis for development activities is expected to provide an opportunity for remarkable competitive advantage for businesses but also for regions [6].

The overall innovation performance of an economy depends not so much on how specific formal institutions (firms, research institutes, universities) perform, but on how they interact with each other as elements of a collective system of knowledge creation and use, and on their interplay with social institutions (such as value, norms and legal frameworks) [7]. Keeble and Wever [8] have introduced their concept on how to create new firms during continuous regional development.

Chesbrough [9] points out there are a new logic behind open innovation which embraces external ideas and knowledge in conjunction with internal R\&D. This offers a novel way of creating value. Tammela and Salminen [10] introduce the interoperability concept through which common innovation of sustainable products and services can be accelerated by an open semantic infrastructure. The open innovation process requires the definition of interoperability in order to achieve a critical level of network dynamics to create new products and services. Skyttner [11] introduces new systems theory with self -organization and evolution. Jamshid [12] introduces that system thinking is the art of simplifying complexity. It is about seeing through chaos, managing interdependency, and understanding choice. Concepts are important to explain chaos. 


\section{Acta Wasaensia}

Every participant in ecosystem has an opportunity to participate on creation of innovations and value, which generally is produced on the boundaries of ecosystem stakeholders [13]. Business ecosystem can be born as group activity or a single company can create it by collaborative activities [14]. It is important that university on the region support co-evolution of municipal and industrial enterprises as well as value networks and through that increasing the competitiveness of the region [15].

\section{Research Questions}

The importance of robotics and digitalization for whole the society will soon increase because of the competitiveness and attractiveness of regions. It is important that the region and cities have a clear vision and intent for the overall development and for the support on exploitation of robotization.

The main topics of discussion are:

5.) The importance of vision and strategy for the area to make full use of robotization.

6.) The importance of education in controlling change during the increase of digitalization

7.) The role of piloting and rapid experimentation in a fast change in management

8.) International relevance of comparability

This article introduces the concept of comprehensive utilization of robotization in the area and thus provides a model for digitalization to bring about social change in the development of regions.

\section{Management of Change in Multidisciplinary and Co-Operative Environment}

Digitalization and robotics changes everything and is a great opportunity to find out competitive advantage in business. Universities of applied science have a good opportunity and central role in supporting the growth of business on the area of digitalization and robotization. The co-operation between government, enterprise and universities is essential to succeed in co-evolution when building up cumulative competence in creation of solutions for robotic by benefiting digitalization in it. It is also essential to have a common vision to direct the local operation and funding. Otherwise, the activities can splinter as small pieces and do not form parts of the whole vision.

Industry 4.0 has can be used as a framework for regional development [6]. It describes and encapsulates a set of technological changes in business environment and sets out priorities of a coherent policy framework with the aim of maintaining the global competitiveness of society. It is conceptual in that it sets out a way of understanding an 
observed phenomenon and institutional in that it provides the framework for a range of policy initiatives identified and supported by government, city and business representatives that drive a research and development program. [4]

Industry 4.0 describes the organization of production processes based on technology and devices autonomously communicating with each other along the value chain: a model of the 'smart' factory of the future where computer-driven systems monitor physical processes, create a virtual copy of the physical world and make decentralized decisions based on self-organization mechanisms. The concept takes account of the increased digitalization of manufacturing industries where physical objects are seamlessly integrated into the information network, allowing for decentralized production and realtime adaptation in the future. [4]

We are increasingly used to the internet of things, or the internet of everything and increasingly the industrial internet. The widespread adoption of information and communication technology (ICT) is increasingly accelerating and blurring of boundaries between the real physical world and the virtual one. The linkage is becoming increasingly Smart. [5]

New ICT-related technologies make Industry 4.0 development possible and give opportunities to re-engineer value chains and create new business models. Internet of Things (IoT) is one of the core technologies for Industry 4.0. The growth of connections brings the new possibilities and solutions for business. On the other hand exponential growth brings also new challenges for education, R\&D\&I and regional development activities. The exponential growth of IoT connections indicates the birth of new business models and new kind of business environments.

This "smartness" requires greater connection and collaborations. This is where the 'explosion' of platforms and ecosystems is occurring [17]. To attempt to connect the internets of things, services, data, and people are needing radical redesigns within industries and the participants to connect all of this up. Presently Industry 4.0 is more industrial driven but this will change and broaden out.

Industry 4.0 and industrial internet can be used to increase the efficiency of processes. Industrial internet enables functional optimization of entire value network and increasing use of material side flows (material and energy efficiency). It is possible to anticipate beforehand the disturbance situation of value network and their repair operations. Collected data from whole the value network can be used for its functional development or forecasting purposes. New entrepreneurship and new digital services can be created through digitalization activities.

In the field of social change, there is little awareness of Industry 4.0 outside the group of key stakeholders. Larger firms tend to be more positively disposed whereas trade unions remain cautious and have reservations. While a skills gap (as well as a gap in willingness) to adjust to the Digital Single Market exists, the skill requirements to adjust to Industry 4.0 are much greater. [4] 


\section{Robotics - Conceptual Model for Adaptive Development}

Robotic and industrial internet are rather new topics and there are few experiences on driving of benefit out of them both in enterprises and universities. That is why cooperation serves developing on collaborative way. Most of the innovations are created at customer interface and co-operative development on common platform, research and learning environment, is essential basis in succeeding on business co- evolution.

Good cooperation requires management engagement, trust building, information, and experience delivering. It happens on various levels of operation; e.g. fore-casting and roadmap-projects, applied research and development projects, on bachelor and masters' thesis works or creation of research and learning environment for experimentation and piloting. It is ought to be continuous on various organization levels. Co-operation and learning together on research and learning environment supplied by university is basis for new innovations and continuous development. Developing of superior competitive power through principals of robotic is built by lean and digitalized value networks. It is important to succeed in benefiting multidisciplinary competence and open information sharing.

Figure 1 describes the conceptual model of adaptive development towards robotics by benefiting value chain management, proper digitalization and data analysis/management. The objective of robotization is efficiency on the use of labour force. The purpose of digitalization is to increase effectiveness on planning and optimization. The objective of using and managing value partners is to increase effectiveness of leadership and organization. The trend in succeeding on robotic is that these functions will be continuously increasingly overlapping. The increasing digitalization and management on data-to-service-process are key enablers in business co-evolution.

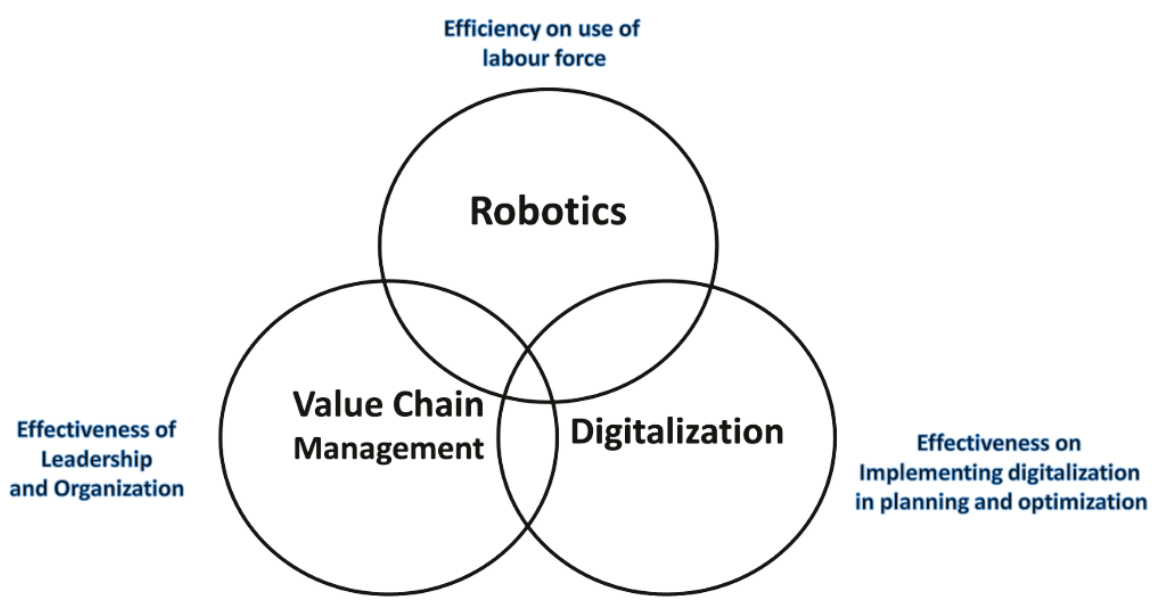

Figure 1. Proper implementation leading on more intensive overlapping 
Succeeding on robotization co-innovation requires data-to-service management process and creation of adaptive multidisciplinary co-operation model for solution development. For research center to be capable to collaborate with industrial companies, it is important to know the overall capability of research and development unit. The experts making applied research with customers have to have content and process knowledge of customer site, they have to be capable to work in teams on distributed way with other experts in value network and have to certain collaborative skills to work together. In our article, we categorize the competence and capability on three layers: content management capability, organization capability and human competence and capability [15].

\section{Applying Industry 4.0 as a Framework for Implementing the Robotic in Regional development}

Attractiveness from various perspectives is important so that region would be seen as an interesting and innovative environment. On the other hand cities and public organizations (for example hospitals, military bases, elderly houses, schools, parks, etc. itself are issues, which use tax money for to maintain the welfare and provide service for people and organizations in the region. Based on that background, it would be justified that public organizations would be acting as "platforms" for different actors. This would allow testing their activities and products in "field labs" where education, research, and testing would take place in the same multidisciplinary environment.

Industry 4.0 would be used as a transdisciplinary framework supporting a development of local service ecosystem. Since Industry 4.0 is a European concept and part of European platform, it is wise that best practices will be benchmarked into European approach and experiences.

The key elements (firure 2) to designing the Local Service Ecosystem for Industry 4.0, are:

- "Smart development areas" - Tavastia region has in its smart specialization strategy announced, that "Industrie 4.0" and Robotics are key elements to develop. future competiveness

- Vision -Riihimäki Town (on Tavastia region) has developing its competiveness based on robotics and has strong vision and commitment on that

- "Field labs" - , Town, companies education institutions and university have strong will to co-operate together and create "real life learning" environment (field labs) for quick trials, and, pilots)

- Education - renew education content so that it response the new ICT-based technologies but also so that there will be robotic related studies in all level of education starting from nursery schools to university level and continuous education. Education will have transdisciplinary approach.

- Benchmarking - Since there is also strong need to create new image for Riihimäki town and be able to implement new strategy fast, it is necessary to make benchmarking for the towns, which are alike and locate on region similar to Tavastia, and which have already taken the steps to adapt Industry 4.0 and to ensure compatibility. 


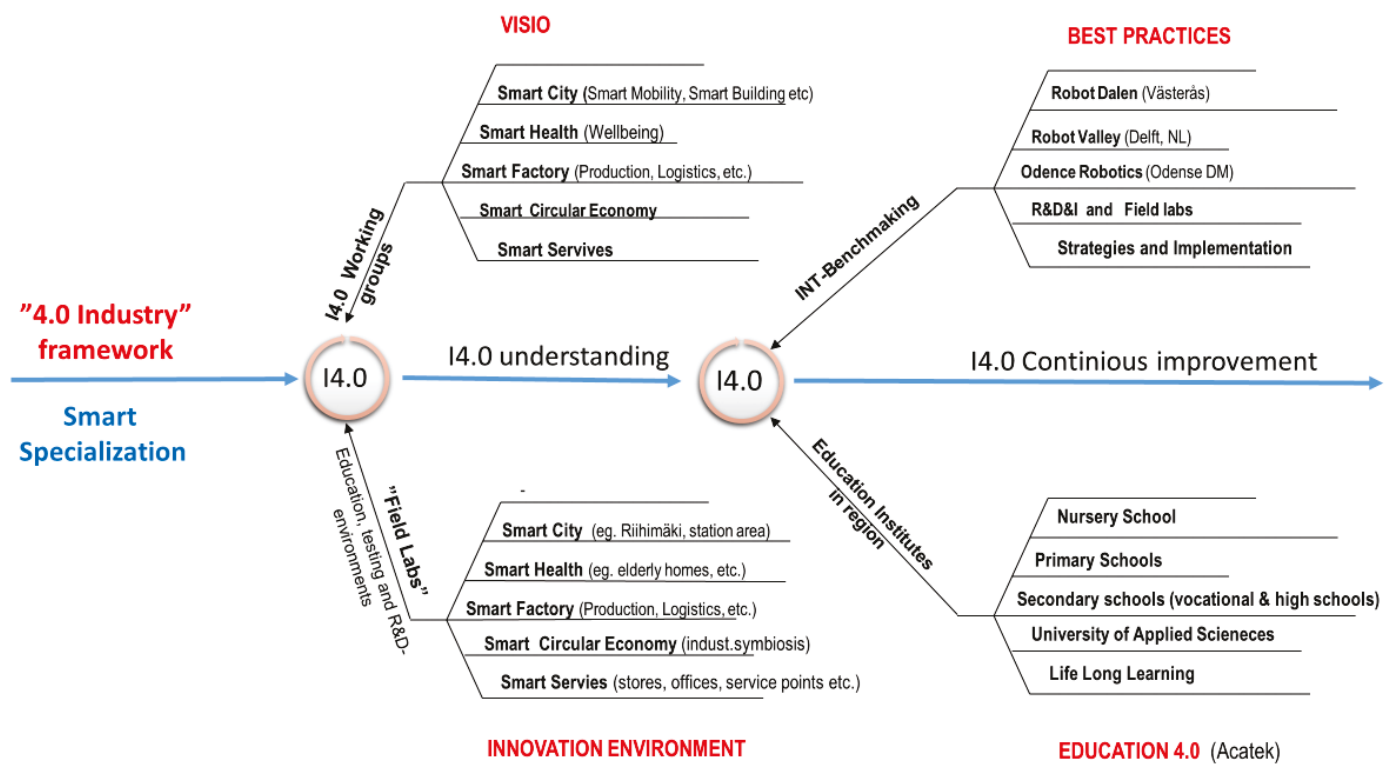

Figure 2. Steps to develop robotic related competitiveness based on smart specialization and "Industry 4.0" framework.

\section{Applying Robotic in Riihimäki town}

Riihimäki town is building its strengths and competitiveness in its own strategy based on the robotic use and thus Riihimäki develops the attractiveness of the business environment. Because of the strategy and guidelines, the management and staff of town are committed to long run development related to the implementation of robotic in the all possible fields of life and working.

The development activities are linked in according to European "Industry 4.0" framework to ensure European comparability and compatibility. On this development stage "industry 4.0" gives more guidelines for development than giving accurate rules or orders.

"Industry 4.0" can be seen as a platform, where we can take to use all the possibilities and benefits that the implementation of robotization can provide. Industry 4.0 gives compatibility and thus the possibility to have the benefits from best practices to the regional development based on robotics.

Industry 4.0 and robotics can also be seen as a brand that can be used to indicate the intent to European Digital Single market and attract new business to town. To ensure the 
implementation it is necessary to have an open atmosphere, so that inhabitants/customers/employees will participate in the development and innovation activities. By inclusioning stakeholders we can achieve less resistance to change, more commitment, opportunities for new ideas and start-ups. The development work will be done by quick pilots in the "real life" environments; like offices, factories, hospitals etc.

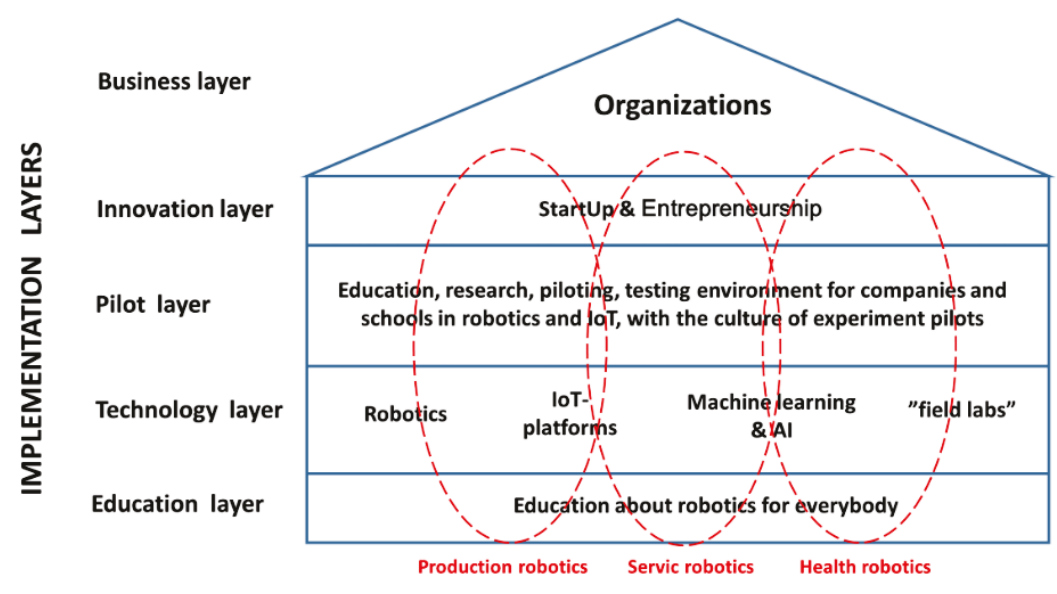

SMART SPECIALIZATION

Figure 3. The "house of robotic development" in Riihimäki town. by Dr Esa Santakallio, Director of Education and Culture at Riihimaki Town (Adapted)

The utilization of robotics and digitalization requires new skills, not only technical, but also multidisciplinary and wide approach. Because that Riihimäki town will offer robot education starting from nursery school to university level and lifelong learning for adult education by integrating it to the needs of all sectors. (Industry, hospital, schools, traffic, etc.)

Education is not seen only to build up versatile knowhow, but also reduce resistance to change, speeding the implementation, and supporting the positive attitude to robotic. Education is also fundament for innovation, when education will take place in "real life" environment by pilots and quick trials

\section{Discussion and Conclusions}

The strategy and development plans of town has been analyzed in this article; how it is trying response the challenge of digitalization and develop its own competiveness to attract new business and inhabitants. The principal idea behind this article has been also to combine the principles of industry 4.0 framework to value network thinking and digitalization on the region. Based on the smart specialization strategy, the town has created the intention, vision, commitment for long run development. It issues the fundament for development of the business environment for all sectors around the town. 
The town will indicate in its strategy the vision and intension to all stakeholders the guidelines of the town and in this way, it will make business environment easier to predict. The vision of the town will guideline the action of other actors (eg. hospitals, schools, services, etc.) to which town has a direct or an undirect administrative connection.

To ensure the change and the implementation of robotics the efforts will be made visible in all sectors in the town by having pilots and quick trials in "a real life" environment.

According to the experiences of the conceptual development work, a successful activity in Industry 4.0 is dependent on systematic long-term development on the public sector. The essential topic is to prepare up to date platforms, which enable, control and support the operation and create a business environment to apply new offering. It is important to give a relevant role for the higher education institutions to provide and support a transdisciplinary approach to study services in a proper operating environment.

\section{References}

19. OECD Comparative Studies Report- Digital Government Strategies for Transforming Public Services in the Welfare Areas (2016). http://www.oecd.org/gov/digital-government/Digital-GovernmentStrategies-Welfare-Service.pdf (read 03.03.2018)

20. Smart Robots for Smart Regions- Sparc 02.05.2017. https://www.eurobotics.net/sparc/newsroom/press/smart-robots-for-smart-regions-strategies-to-unleash-the-potentialof-the-digital-economy-in-europe.html (read 03.03.2018).

21. International Federation of Robotics-IFR Press Releases (2017) Why service robots are booming worldwide. Frankfurt, Brussels, Oct 11, 2017 https://ifr.org/ifr-press-releases/news/why-servicerobots-are-booming-worldwide (read 03.03.2018)

22. European parliament, briefing (Sept 2015) 4.0 Industry digitalization for productivity and growth $\mathrm{http} / / / \mathrm{www}$.europarl.europa.eu/thinktank (internet)

23. Deloitte (2015) Industry 4.0 challenge: Challenges and solutions for the digital transformation and use of exponential technologies.

24. Ruohomaa, H. Mäntyneva, M., Salminen, V. (2018) Renewing a University to Support Smart Manufacturing within a Region. Digital Transformation in Smart Manufacturing-Book, Chapter 8, InTech -Open Science|Open minds.

25. Clarke, T., Chelliah, J., Pattinson, E., National Innovation Systems in the Asia Pacific: A Comparative Analysis

26. Keeble, D., Wever E. (2016) New Firms and Regional Development in Europe

27. Chesbrough H. (2003) Open Innovation: The New Imperative for Creating and Profiting from Technology. Harvard Business School Publishing Corporation, Boston.

28. Tammela, J., Salminen, V. (2007) Interoperability concept supporting Network Innovation. Information Technology Entrepreneurship and Innovation (chapter on a Book), Publisher Group Inc., Hershey, PA, U.S.A, 2007 
29. Skyttner, L. (2005), General Systems Theory: Problems, Perspectives, Practices. World Scientific Publishing, Singapore.

30. Jamshid, G. (1999) System Thinking: Managing Chaos and Complexity. A Platform for Designing Business Architecture. Butterworth- Heinemann, Woburn, MA, USA.

31. Iansiti, M. \& Levien, R. (2004) The keystone advantage: what the new dynamics of business ecosystems mean for strategy, innovation, and sustainability. Boston: Harvard Business School Press.

32. Järvi, K. (2013). Ecosystem architecture design: Endogenous and exogenous structural properties. Lappeenranta: Dissertation, Lappeenranta University of Technology.

33. Salminen, V., Kantola, J., Vanharanta, H. (2015) Competence portfolio assessment of research and development center for regional development. Elsevier Publishing, Science Direct, Procedia Manufacturing 3 ( 2015 ) 701-708.

34. Ruohomaa, H., Kantola, J., Salminen, V. (2018) Value Network Development in Industry 4.0 Environment, Book Chapter. Advances in Human Factors, Business Management and Leadership, Springer International Publishing AG

35. PwC report (2016) 4.0 Industry: Building the digital enterprise. Global Industry Survey 
142 Acta Wasaensia

\section{ORIGINAL PUBLICATION F}

Publication F. Mobility as a service in smart cities - new concept for smart mobility in Industry 4.0 framework

Authors: Heikki Ruohomaa, Vesa Salminen

ISPIM2018 Innovation for Local and Global Impact, 7-10 April, Ottava Canada 


\title{
Mobility as a service in smart cities - new concept for smart mobility in Industry 4.0 framework
}

\section{Heikki J. Ruohomaa*}

Häme University of Applied Sciences, Visamäentie 35A, 13100 Hämeenlinna, Finland.

E-mail: heikki.ruohomaa@hamk.fi

\section{Vesa K. Salminen}

Häme University of Applied Sciences, Visamäentie 35A, 13100 Hämeenlinna, Finland.

E-mail: vesa.salminen@hamk.fi

* Corresponding author

\begin{abstract}
Because of fast change and complexity of business environment organization are moving towards ecosystem-based development. Increasing amount of data and increasing importance of digitalization forces organization to pay attention also to development of digital ecosystems. In city context it is important to have also pilot project in order to recognize potential problems. As ecosystem development Hameenlinna city has chosen smart mobility pilot one of the concepts. Key focus on development work is to understand the possibilities and problems related to electric city bike services and how collected data could be used to improve city services and as a fundament for new innovations
\end{abstract}

Keywords: Smart City; ecosystem-based development; electronic bike; Industry 4.0; Mobility as a Service (MaaS).

\section{Introduction}

The societies, not just corporations, but also cities and regions are in fast change because of globalization, climate change, environment changes, increasing amount of data etc. The speed of change and its complexity will challenge also leadership, structures of organizations, $R \& D$ activities, renewing education and also reengineering of value chains in order to maintain competiveness. Ecosystem-based development has considered to be one option to manage the change on government, national, regional and company level.

The World Economic Forum report (Fourth Industrial Revolution for the Earth Series, 2018), has termed this period of accelerating innovation in science and technology - the transformative change in data and technology capabilities combined with a merging of digital, physical and biological realms and its consequences on society as the Fourth Industrial Revolution. It is not only transforming social networks, scientific research and whole industries; it is also radically reshaping biological and material science innovations. Harnessing these opportunities and proactively managing the risks manifest by the rapid evolution of new science and technologies will inevitably require more creativity and agility in current governance frameworks and financing arrangements. 
To be successful on new challenges of Industry 4.0 development, enterprise-university partnerships has to be intense and main objective should be a shared learning (Ruohomaa, H. Mäntyneva, M., Salminen, V., 2018). Long-term co-operation creates a background for new co-innovation and co- evolution. The technologies of the Fourth Industrial Revolution have generated enormous excitement about the opportunities they offer as well as concern about governance, regulation and ethics (Fourth Industrial Revolution for the Earth Series, 2018). There are as well exciting possibilities: The convergence of new technologies is creating unprecedented opportunities in all aspects, from business-tobusiness commerce to humanitarian intervention. The melding of artificial intelligence (AI) with big data capabilities - not to mention the actual exponential accumulation of data itself - has created a fascinating world of communications, collaboration and interaction, not just between people but also between machines and between people and machines. Through digital transformation, the use of new technologies like big data, open data, cloud, IoT, platforms, artificial intelligence, and social networks with increasing intelligence and automation enterprises can capitalize on new opportunities and optimize existing operations to achieve significant business improvement (Salminen, V., Kantola, J., Ruohomaa, H., 2016). The collection of scattered data, clustering it for analysis, visualizing it for decision making and using the selected data in new service development on mobility is most important in creating city services on value network.

Today, $55 \%$ of the world's population lives in urban areas, a proportion that is expected to increase to $68 \%$ by 2050 (United Nations, 2018). This increasing urbanisation will add to existing problems of traffic congestion.

Public transport authorities are increasingly looking to embrace innovative technology to meet user expectations and enable travellers to personalise their journeys (Racontour, 2018). In the transport sector, ensuring the effectiveness of the market is highly topical. Transport services are meant to be converted into a service package along the lines of the communications service sector. In the future various transport service chains should work seamlessly together (LVM Ministry of transportation and communication, 2019) [6].

Hämeenlinna city has in its ecosystem-based development work faced cumulative increase of data and used new technologies in order to response the fast change and complexity of business environment. In this article is introduced a case study of mobility (bike) as the very first step towards ecosystem-based development in Hämeenlinna.

\section{Theoretical background}

The smart city concept integrates the information and communication technology (ICT), physical Internet of things, and IoT-devices to optimize the efficiency of city operations and services (Peris-Ortiz et al., 2016). Transportation is an important part of the concept of smart cities, and the main goal is to ensure safe and effective mobility of individuals and goods in a way that minimizes the $\mathrm{CO} 2$ emissions. Thus, transportation should not be viewed as simple "moving people and goods from one place to another" (Wensveen, J. G., 2015), but transportation should be understood as a service, in which timely delivery of people and goods in target destination is emphasized.

The concept of "Mobility-as-a-Service (MaaS)" describes a shift away from personally- 
owned modes of transportation and towards mobility solutions that are consumed as a service. The concept is based on the combination of public and private transportation services through a unified gateway that creates and manages the trip, and which the users can pay for with a single account. The fees can be paid on single trip basis or alternatively paying a monthly fee. In this manner, the key principle of MaaS is to offer traveler's mobility solutions based on their personal needs (Wikipedia 2019). In the MaaS distribution model, the customer's major needs for transportation are met from a single platform, in which the services are bundled into a monthly packages. Overall, MaaS depends on viewing the provision of transport as a co-operative, interconnected ecosystem, providing cost-effective services that are personalized to meet customer needs (ITS Finland, 2019).

Industry 4.0 framework defines the context for digitalization and IoT in industrial context. This "Smart industry" framework contains the connectivity of devices for effective value chain management using sophisticated data collection as well as data-based optimization and analysis. Industry 4.0 gives a detailed and solid framework also to the development work related to smart cities (Lom, M., Pribyl O., Svitek, M., 2016). It is proposed to see the Industry 4.0 as a building block of smart cities, among other objects such as smart building, smart street, or smart campus. In this paper, we suggest that Smart transportation through Industry 4.0 framework and the concept of smart city can be combined in the process of designing a platform for smart mobility in smart cities. The goal of this paper is to find answers to a research question: How smart transportation solutions can be designed in an efficient manner in the smart city concept following the Industry 4.0 standard? We approach the question by using the concept of mobility as a service (MAAS) from customer point of view. The business architecture following the principles of Industry 4.0 framework is developed in the context of smart traffic and network business point of view.

In year 2018 Finland was the first country in the world to create an open market for mobility services. As of January 2018, all mobility partners must provide open data and associated computer programs (APIs) to third parties (The Conversation, 2018).

"Digital business drives dramatic changes in organizations' business ecosystems, making them larger, more complex and essential to strategy," Ecosystems enable organizations to respond and exist in an increasingly digital world, assuming that the actors consider the dimensions when making strategic decisions about how to participate and when to change tactics. (Kasey Panetta, Gartner, 2017).

The Internet has transformed the world economic landscape, and this transformation is expected to continue with the Internet of things (IoT). (Rifkin, 2014) confirms this trend in his concept of zero marginal cost, which emphasizes connectivity in his anticipation of a collaborative economy that will replace the capital system in its current form - with the IoT as the main driver. The rapid progress of smart cities is also paving the way to a more collaborative world (Kanter \& Litow, 2009). 


\section{Research approach}

The smart city concept integrates the information and communication technology (ICT), physical Internet of things, and IoT-devices to optimize the efficiency of city operations and services (Peris-Ortiz et al., 2016). New technologies and huge amount of data forces also organizations to change. That is the reason why many organizations are developing their activities toward ecosystem-based development.

The main topics of discussion are:

1. Availability of city environment as open platform

2. Open data availability in ecosystem-based innovation

3. The importance of piloting and rapid experimentation on open city platform

4. The role of functional architecture in ecosystem development

In this study have used qualitative and case study research approach.

This article introduces a mobility as a service in smart cities - new concept for smart mobility in Industry 4.0 framework. It provides a case study as a part of Hämeenlinna city ecosystem- based development.

\section{Ecosystem based-development}

Good ecosystems do not start by administrative decision. It takes time, need strong vision, will and hard work. The fundament for fruitful cooperation is trust, sharing information and understanding for continuing change and the change of roles of partners.

The dynamic business ecosystems may sometimes create competitors as partners, at least for a little while. When there is need to develop key technologies, they may join together and then later on compete for the marketplace. In a less-competitive ecosystem, groups such as a government, charity and a community group might collaborate on health or public policy because each entity has a shared interest and goal.

Every organization exists in multiple business ecosystems. These business ecosystems are dynamic networks of entities interacting with each other to create and exchange sustainable value for participants. The challenge is deciding how your organization will survive and thrive in its ecosystem (Kasey Panetta, Gartner, 2017).

With increased connectivity, organizations will need to figure out how to integrate things like smart advisors and artificial intelligence into their ecosystems. It is important to understand that the diversity of an ecosystem and the roles that people, businesses and things play will change and evolve depending on the current situation.

It is the technology that will enable the business ecosystem strategy now and in the future. Leverage a digital business platform (i.e., open APIs, analytics, security capabilities, etc.) Success will require a strategic integration of technology, information and business processes.

MaaS requires a willingness by private and public transport providers to work with the creators of MaaS platforms. Transport providers must agree to allow the MaaS operator to sell their services and collect a "reasonable" and "fair" commission for each ticket sold 
(The Conversation, 2018). The challenge is not about the technology - it is about governance.

Organizations that do not work towards of understanding their business ecosystems risk falling into a participatory role only, enabling other competitors or partners to take the leadership role and thus define the rules for engagement in that ecosystem (Kasey Panetta, Gartner, 2018).

To build up ecosystem is long process, which need clear vision, strategy, scenarios, but also it need clear roadmap with clear systematic steps and understanging the heritage of ecosystem fundaments. (fig 1.)

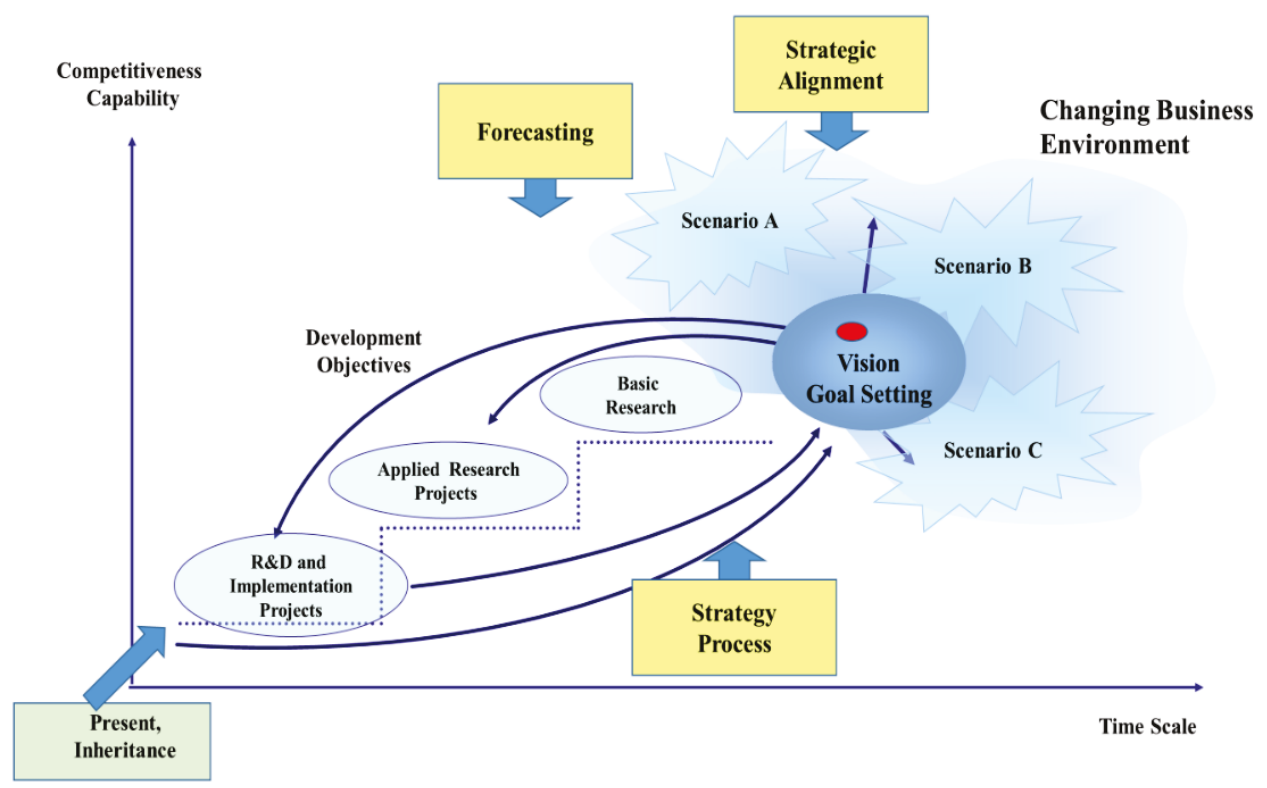

Fig 1. Roadmap for ecosystem-based development.

The degree of openness within ecosystems is driven by strategies, common goals and shared interest. An ecosystem may be public, private or a hybrid. Many organizations actually participate in a hybrid of public and private ecosystems.

The openness of an ecosystem has two implications. The degree of change is dependent upon the possibility of new entrants and disruption to relationships and value. It will also define the nature of the relationships in the ecosystems and how they are formed and maintained. It will define the nature of collaboration and competitions (Kasey Panetta, Gartner, 2017).

\section{Industry 4.0}

The term "Industrie 4.0" was initially coined by the German government. It is conceptual in that it sets out a way of understanding an observed phenomenon and institutional in that it provides the framework for a range of policy initiatives identified and supported by government and business representatives that drive a research and development programme (European parliament, briefing, 2015). In the field of social change there is 
little awareness of Industry 4.0 outside the group of key stakeholders. Larger firms tend to be more positively disposed whereas unions remain cautious and have reservations. While a skills gap (as well as a gap in willingness) to adjust to the Digital Single Market exists, the skill requirements to adjust to Industry 4.0 are much greater (European parliament, briefing, 2015).

The physical world is merging with the virtual world. We are increasingly used to the internet of things, or the internet of everything and increasingly the industrial internet. They all are in the throes of digital transformation. The widespread adoption of information and communication technology (ICT) is increasingly accelerating the blurring of boundaries between the real physical world and the virtual one. The linkage is becoming increasingly smart (Deloitte, 2015). New ITC based technologies make possible Industry 4.0 development and give opportunities to reengineer value chains and create new business models. Internet of Thinks (IoT) is one of the technological fundaments for Industry 4.0. Growth of connections brings the new possibilities and solutions for business. On the other hand exponential growth brings also new challenges for education, R\&D\&I and regional development activities. The exponential growth of IoT connections indicates the birth of new business models and new kind of business environments (Deloitte, 2015). This "smartness" requires greater connection and collaborations. This is where the 'explosion' of platforms and ecosystems is occurring. To attempt to connect the internets of things, services, data, and people need radical redesigns within industries and the participants to connect everything. Presently Industry 4.0 is more industrial driven but this will change and broaden out (PwC, 2016).

\section{Mobility as a Service (MAAS)}

Mobility as a Service brings every kind of transport together into a single intuitive mobile app. It seamlessly combines transport options from different providers, handling everything from travel planning to payments. Whether you prefer to buy journeys on demand or subscribe to an affordable monthly package, MaaS manages your travel needs in the smartest way possible.

It's clear the user base of MaaS solutions is still small compared with traditional transport services, but the growing number of pilot MaaS projects indicates that the sector is coming closer towards an inflection point, with advisory firm ABI Research expecting global MaaS revenues to reach $\$ 1$ trillion by 2030 (Racontour, 2018,).

MaaS is a hassle-free and environmentally sound alternative to private car ownership. It makes worries about route planning, parking, and car maintenance a thing of the past, helping you go places easier and more efficiently than ever before.

The MaaS concept was born in Finland where it already plays a key role in the national transport policy. It is widely recognized as a disruptive innovation, which will change the entire transportation universe through digitalization and combining the best of existing apps (Maas Global, 2019).

There are three reasons to believe that MaaS could quickly evolve beyond the pilot stage.

a. Simply adding more roads, more trains, and more parking garages is unlikely to solve the problems of our congested urban areas. 
b. Non networked forms of transportation don't meet the needs of the modern urbanite.

c. The technology that makes MaaS work is already here.

With smartphones and 4G/5G networks, deep learning and artificial intelligence, autonomous drive and dynamic routing, the world is ready to build and run the new services most in demand (Deloitte Rewiew, 2017)..

Municipal transportation should be included. Buses and trains that serve citizens today can't be excluded from the MaaS ecosystem. It's often logical to leverage the payment systems for buses and trains that already exist and operate on the back end. MaaS represents the next evolution in mobility. If it's not there already, it's coming to a city near you (Deloitte Rewiew, 2017).

An important factor in making MaaS a success will be getting all of the players to work together.

\section{Smart City Mobility as a Service development concept}

Hameenlinna city has decided in its own strategy to focus on five key areas of ecosystemic development work. Key actors (companies, university, educators, inhabitants etc.) have been invited for this development work.

It has understood that ecosystem-based development need pilot project. The aim of pilot project is to be able to integrate data from different domains and thus make digitalecosystem. In order to make attractive pilot environment there have to be large enough platform. In Hameenlinna is proposed that new part of town would be considered to be also development and innovation environment and platform for new technology and $5 \mathrm{G}$ communication. In this area open data would be open for new start-ups, research and innovations.

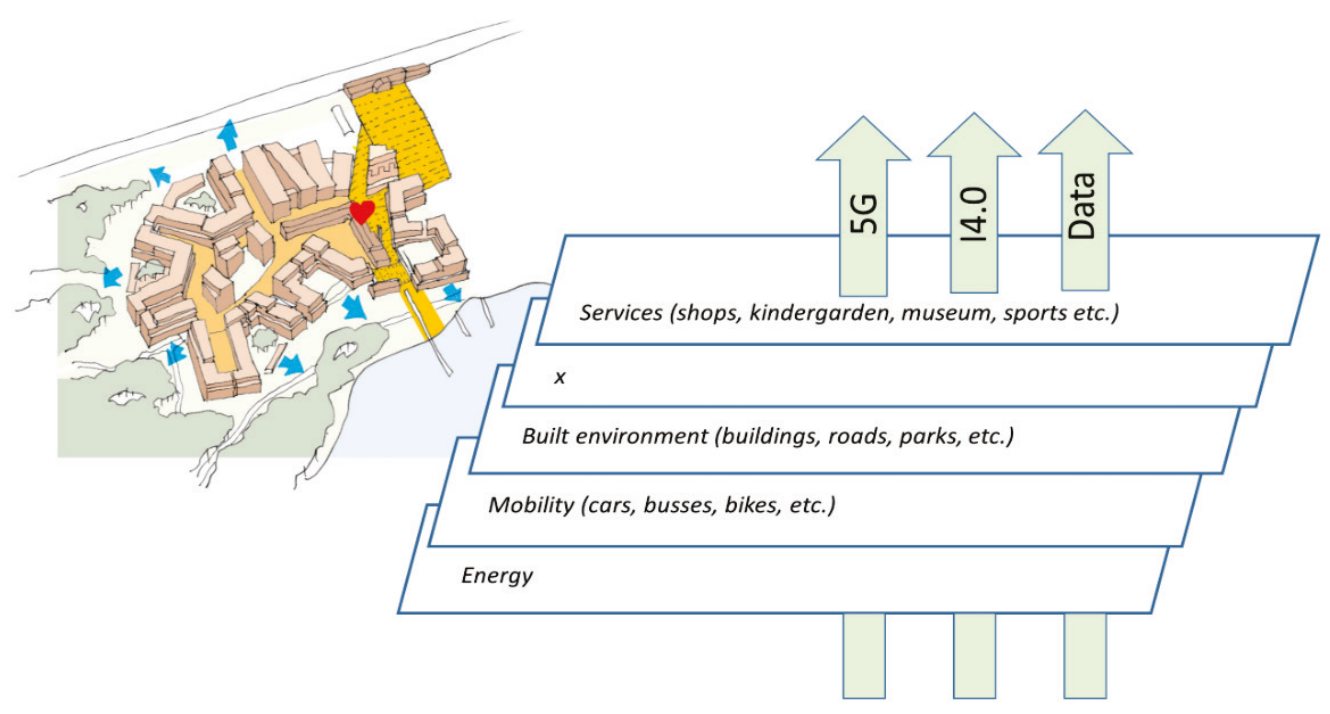

Fig 2. Ecosystem based innovation platform 
Ecosystem based city development needs innovation platform (fig 2.). Building blocks are common platform, common technology, common architecture, sharing data and also common goal. Innovations are created on the interfaces of various partners from different domains.

One of the very first pilot projects was chosen the electronic bike service and the data that could be collected and used related to it (fig 2.)

The role of the public sector is to enable and create favorable operating conditions. The responsibility for innovations and service development lies with the private sector. Finland is a pioneer in this "mobility as a service" thinking (LVM Ministry of transportation and communication, 2019).

In a recent DATAVERSITY ${ }^{\circledR}$ interview, Nutley said the needs of three groups come into play when planning a bike share solution: The city, the users, and the program operator. "Each city is different, with hundreds of different parameters, such as the amount of public transport available, the number of train and bus stations, the weather, the topography," he said. (Amber Lee Dennis, 2018).

Rather than being seen just as a fun alternative, bike share operators and the cities where they operate want bike share travel to be seen as a viable part of the transportation system for city residents. "For bike share schemes to be seen as a real public transport solution and a smart answer to urban mobility, they need to work as good or better than existing public transport services," said Paul Stratta, (Amber Lee Dennis, 2018).

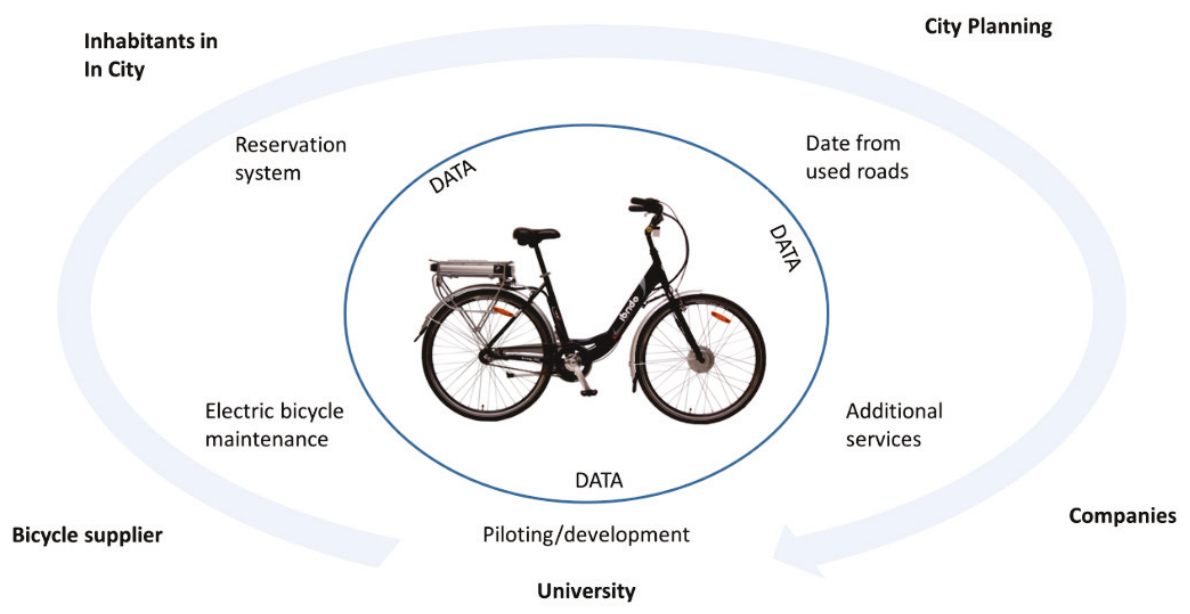

Figure 3. The pilot of electric bicycle digital ecosystem

Bike share ridership fluctuates based on external factors such as weather, events, and holidays, and Nutley said that redistribution of bicycles in response to those factors is 4060 percent of the operations costs of running a bike share scheme. The need to keep bikes repaired and serviced is also a challenge, yet simply adding more bikes is not the 
solution. "In reality this does little to increase efficiency and often adds to the problem." he said. (Amber Lee Dennis, 2018).

The electric bike development is made to serve public mobility, but it is also one of the first pilot of ecosystemic development project in the city of Hämeenlinna (fig 3). The case study is divided into three parts.

In the first part (Reservation system), we involve city inhabitants as well as university students in the planning and design on a smart city mobile application for reservation for electric city bike.

In the second part (Maintaining service system), we carry out a pilot to the maintaining the electric bike service system and optimization of maintenance system.

In the third part (Smart city planning), the data from bicycles and users are collected. Based on that collected data it is possible to make predictions, how people move (time, amount, roads etc.) and based on that analysis different services and infra can be designed.

Technology architecture should be agreed upon. Municipalities should create an open architecture that private partners can integrate to, but that still meets the needs of their citizens. Again, private-sector partners can support cities in this effort. (Deloitte Rewiew, 2017).

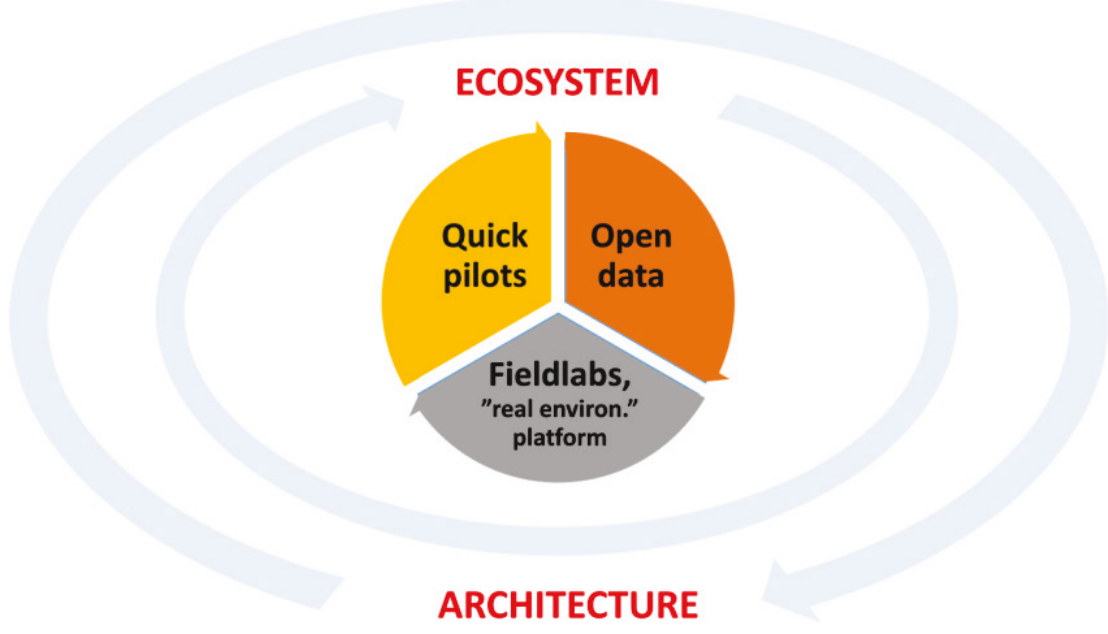

Figure 4. The birth of innovation in digital ecosystem

Fundament for piloting is common understanding about the form and architecture of data, understanding the ecosystem/actors around it. There have to be a platform available and a 


\section{Acta Wasaensia}

possibility to make quick piloting. Hämeenlinna city has provided its city environment as platform for bike piloting.

In its legislative work, the Finnish State has supported the use of open data on traffic in the development of new transport services. As well the regional council has provided fund for smart city mobility piloting. Piloting gives an idea of the importance of a common architecture Industry 4.0 approach as business architecture for networked partners.

\section{Discussion and Conclusions}

Based on the research literature review, it is stated that finding new urban mobility solutions is necessary because of urbanization, the need for residents, technological development and environmental challenges.

Technology and 5G data transfer are already providing new services and enabling the development of MaaS. The problem of traffic development is not technology but primarily governance. Smart mobility development is shifting from a piloting and linear growth phase to an implementation and exponential growth phase.

The public sector is creating a framework for mobility, but public-private cooperation is essential. Also transport providers must agree to allow the MaaS operator to sell their services and collect a "reasonable" and "fair" commission for each ticket sold (The Conversation, 2018). Technology architecture should be agreed upon. Municipalities should create an open architecture that private partners can integrate to. That should still meet the needs of the citizens.

The study provides practical viewpoints and experiences on the planning of mobility and the availability of services and also on the use of it as a tool for city planning, in smart city context. In this way, it may provide helpful "lessons learned"-type of information for all the actors involved and interested in participation by developing mobility services in a city (also the fundament of service itself).

This case study is part of larger development where the city is moving its development activities towards ecosystem based development and thus changing its organization so that it is able to response the impact of digitalization, increasing amount of data, $5 \mathrm{G}$, etc. in a better way.

\section{Acknowledgment}

The authors wish to thank the Regional Council of Häme for financial support. 


\section{References}

Amber Lee Dennis, (June 14, 2018). Case Study: Artificial Intelligence Helps Bike Share Programs Get Smart, https://www.dataversity.net/case-study-bike-share-programs-get-smart-artificialintelligence/?fbclid=IwAR3adaqrjIFnRInmKTEVd7XSEsVwe0ny tLWLZI4L97OgRmX8_pAowDrTK9

Deloitte (2015) Industry 4.0 challenge: Challenges and solutions for the digital transformation and use of exponential technologies

Deloitte Rewiew, (Issue 20, 2017). The rise of mobility as a service,

https://www2.deloitte.com/content/dam/Deloitte/nl/Documents/consumer-business/deloitte-nl-cb-ths-riseof-mobility-as-a-service.pdf

European parliament, briefing (Sept 2015) 4.0 Industry digitalization for productivity and growth. $\mathrm{http} / / / \mathrm{www}$. europarl.europa.eu/thinktank (internet)

ITS Finland (2019), http://www.its-finland.fi/index.php/en/palvelut/mobility-as-a-service.html

Fourth Industrial Revolution for the Earth Series (2018): Harnessing the Fourth Industrial Revolution for Life on Land- Towards an Inclusive Bio-Economy. World Economic Forum, January 2018, Geneva, Switzerland

Kasey Panetta, Gartner, (July 12 2017). Eight Dimensions of Business Ecosystems https://www.gartner.com/smarterwithgartner/8-dimensions-of-business-ecosystems/

Lom, M., Pribyl O., Svitek, M. (2016) Industry 4.0 as a Part of Smart Cities, Smart Cities Symposium 2016 .

LVM Ministry of transportation and communication (2019) https://www.lvm.fi/en/services

Maas Global (2019) https://maas.global/what-is-mobility-as-a-service-maas/

Moss Kanter, R., \& Litow, S. S. (2009). Informed and Interconnected: A Manifesto for Smarter Cities. Harvard Business School Working Paper 09-141. Boston, MA: Harvard Business School

Peris-Ortiz, Marta; Bennett, Dag R.; Yábar, Diana Pérez-Bustamante (2016). Sustainable Smart Cities: Creating Spaces for Technological, Social and Business Development. Springer. ISBN 9783319408958.

PwC, (2016) 4.0 Industry: Building the digital enterprise. Global Industry Survey

Racontour, (Sep 11 2018). MaaS: Changing the way you travel. https://www.raconteur.net/technology/maas-changing-travel

Rifkin, J. (2014). The Zero Marginal Cost Society: The Internet of Things, the Collaborative Commons, and the Eclipse of Capitalism. New York: St. Martin's Press.

Ruohomaa, H. Mäntyneva, M., Salminen, V. (2018) Renewing a University to Support Smart Manufacturing within a Region. Digital Transformation in Smart Manufacturing-Book, Chapter 8, InTech Open Science|Open minds.

Salminen, V., Kantola, J., Ruohomaa, H. (2016) Digitalization and Big Data Supporting Responsible Business Co-Evolution. 2nd International Co- Evolute Conference on Human Factors, Business Management and Society (Inside AHFE 2016), Orlando, USA July 27-31, 2016.

The Conversation, (Nov 18 2018). For Mobility as a Service (MaaS) to solve our transport woes, some things need to change, http://theconversation.com/for-mobility-as-a-service-maas-to-solve-our-transport- 


\section{Acta Wasaensia}

woes-some-things-need-to-change-105119

United Nations (2018 May 15). https://www.un.org/development/desa/en/news/population/2018-revisionof-world- urbanization-prospects.html

Wensveen, J. G. (2015) Air transportation: A management perspective. Ashgate Publishing, Ltd.

Wikipedia (2019) https://en.wikipedia.org/wiki/Mobility_as_a_service 
ORIGINAL ARTICLE G

Publication G. Ecosystem of Ecosystems in Intercity Biking Authors: Heikki Ruohomaa, Vesa Salminen AHFE2020 the San Diego July 16-21, 2020 


\title{
Ecosystem of Ecosystems in InterCity Biking
}

\author{
Heikki Ruohomaa $^{1}$, Vesa Salminen ${ }^{1}$, Jukka Pulkkinen ${ }^{1}$ \\ ${ }^{1}$ Häme University of Applied Sciences, Hämeenlinna, Finland \\ heikki.ruohomaa@hamk.fi,vesa.salminen@hamk.fi,jukka.pulkkinen@hamk.fi
}

\begin{abstract}
Digitalization, megatrends, the new opportunities offered by technologies have caused societies to break through towards the fourth industrial transformation. It will change the whole society and its structures alongside the business. All societies, not just corporations, but also cities and regions, have to prepare for the change caused by digitalization. That challenges also traditional organizational structures. This requires a new type of business operation and organization.

Cities are responding to the rapid progress of society and are moving from traditional organizational structures to ecosystem development. They are building their own network to involve in developing new operations. While cities largely receive their own funding as taxes, development and change management must be considered in the same way as in businesses. A key measure of efficiency is the improved service and achieved cost efficiency. The article examines the city biking ecosystem development on the Finnish Growth Corridor.
\end{abstract}

Keywords: Ecosystems $\cdot$ biking $\cdot$ management of change $\cdot$ smart city

\section{Introduction}

Public transport authorities are increasingly looking to embrace innovative technology to meet user expectations and enable travelers to personalize their journeys [1]. In the transport sector, ensuring the effectiveness of the market is highly topical. Transport services are meant to be converted into a service package along the lines of the communications service sector. In the future various transport service chains should work seamlessly together [2].

InterCity biking in this context means that when citizen is moving from a town to other the citizen can use bikes in both towns, even if the trip between towns itself will be taken with bus or train. City bikes are often strategic aligning for cities to improve the flexibility of traffic and improve the image of the city. City bikes have also been marketed as a non-polluting solution.

In order to increase intercity cycling, and related mobility between various cities, it must be considered the whole ecosystem around cycling. It may as well include the coordination of a single intercity cycling system or co-operation between separate systems.

The main goal of intercity bike systems is to improve the image of the city, to increase its attractiveness and to build flexible travel chains as part of the development of public transport. It is the objective to move car traffic from the city centers. The proliferation of bike systems requires that their utilization rate is high enough. It indicates then profitability and necessity (customer satisfaction).

Data collected (or the ability to collect) from city bikes is still fragmented and sometimes not used at all. In general, it is observed that data acquisition is largely neglected in the procurement of city bikes. 
In this article is introduced a case study of mobility (bike) as the very first step towards ecosystem-based intercity biking fleet development in Finnish Growth Corridor

\section{Theoretical Background}

The smart city concept integrates the information and communication technology (ICT), physical Internet of things, and IoT-devices to optimize the efficiency of city operations and services [3]. Transportation is an important part of the concept of smart cities, and the main goal is to ensure safe and effective mobility of individuals and goods in a way that minimizes the $\mathrm{CO}^{2}$ emissions. Thus, transportation should not be viewed as simple "moving people and goods from one place to another" [4]. propose, that transportation should be understood as a service, in which timely delivery of people and goods in target destination is emphasized.

Mobility-as-a-Service (MaaS) describes a shift away from personally-owned modes of transportation towards mobility service solutions. In the MaaS distribution model, the customer's major needs for transportation are met from a single platform, in which the services are bundled into monthly packages. Overall, MaaS depends on viewing the provision of transport as a co-operative, interconnected ecosystem, providing costeffective services that are personalized to meet customer needs [5].

The Internet has transformed the world economic landscape, and this transformation is expected to continue with the Internet of things (IoT). Rifkin [6] confirms this trend in his concept of zero marginal cost, which emphasizes connectivity in his anticipation of a collaborative economy that will replace the capital system in its current form - with the IoT as the main driver. The rapid progress of smart cities is also paving the way to a more collaborative world [7].

Appearance of city bikes are changing our understanding about biking. City bikes are moving biking to towards biking as a service. City bikes are boosted also with utilization of digital platforms.

When we design city bike system, it can be seen as a part of business ecosystem, which are interfacing digital ecosystems. Thus, bikes are part of transport/mobility ecosystems and also part of mobility digital ecosystems. City biking is also reflecting to the change in environment (eg. weather, traffic arrangements, etc.)

Connecting biking data to some other data sources, in order to create new services or start-ups, might support the growth of biking.

Through digital transformation, the use of new technologies like big data, open data, cloud, IoT, platforms, artificial intelligence, and social networks with increasing intelligence and automation enterprises can capitalize on new opportunities and optimize existing operations to achieve significant business improvement [8]. 


\section{Acta Wasaensia}

The smart city concept integrates the information and communication technology (ICT), physical Internet of things, and IoT-devices to optimize the efficiency of city operations and services [3]. New technologies and huge amount of data forces also organizations to change.

\section{Research Questions}

The aim of this study is to introduce digital ecosystem for InterCity based city biking at Finnish Growth Corridor.

The main topics of discussion are:

1. How the intercity biking chain is formed?

2. What type of shared data architecture should be built for intercity biking?

3. What are the key elements of digital ecosystem on intercity biking?

4. What are the motivation factors to follow the human ecosystem-based development and business transition?

\section{Digital and Business ecosystems}

Bikes as vehicles are the part of bigger transport ecosystems. Bikes are a part of daily life of the people/transportation. Bikes are also part of transport mobility planning of city. Digitalization gives new possibilities to develop new digital ecosystems around biking and thus create new services to support it.

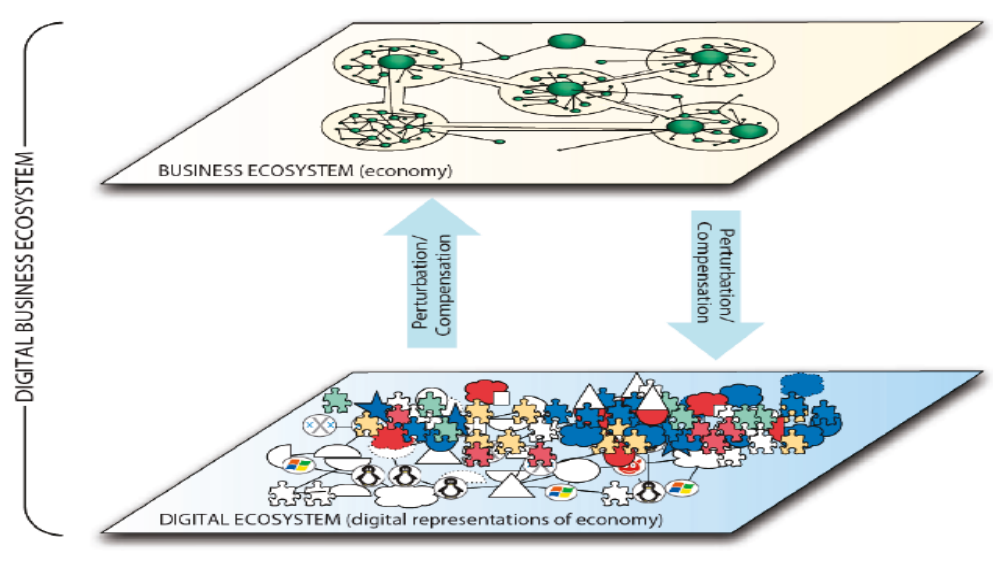

Fig.1 Digital ecosystem and business ecosystem will be connected in order to create flexible services.

Growth of connections brings the new possibilities and solutions for business.

Exponential growth brings also new challenges for education, R\&D\&I and regional 
development activities. The exponential growth of IoT connections indicates the birth of new business models and new kind of business environments [9]. This "smartness" requires greater connection and collaborations. This is where the 'explosion' of platforms and ecosystems is occurring. To attempt to connect the internets of things, services, data, and people need radical redesigns within industries and the participants to connect everything. Presently Industry 4.0 is more industrial driven, but this will change and broaden out [10].

It is the technology that will enable the business ecosystem strategy now and in the future. Success will require a strategic integration of technology, information and business processes.

Technology architecture should be agreed upon. Municipalities should create an open architecture that private partners can integrate to, but that should meet the needs of their citizens [11]. The problem of traffic/mobility development is not technology but primarily governance [12].

Every organization exists in multiple business ecosystems. These business ecosystems are dynamic networks of entities interacting with each other to create and exchange sustainable value for participants. The challenge is deciding how your organization will survive and thrive in its ecosystem [13].

The degree of openness within ecosystems is driven by strategies, common goals and shared interest. An ecosystem may be public, private or a hybrid. Many organizations actually participate in a hybrid of public and private ecosystems.

The openness of an ecosystem has two implications. The degree of change is dependent upon the possibility of new entrants and disruption to relationships and value. It will also define the nature of the relationships in the ecosystems and how they are formed and maintained. It will define the nature of collaboration and competitions [13].

Bike share ridership fluctuates based on external factors such as weather, events, and holidays, and Nutley said that redistribution of bicycles in response to those factors is 40 60 percent of the operations costs of running a bike share scheme. The need to keep bikes repaired and serviced is also a challenge, yet simply adding more bikes is not the solution. In reality this does little to increase efficiency and often adds to the problem. [14]. Most important on all viewpoints is to understand the digital human- oriented experience in the development of intercity biking system.

\section{Biking ecosystem as the ecosystem of ecosystem}

Rather than being seen just as a fun alternative, bike share operators and the cities, where they operate, want bike share travel to be a viable part of the transportation system for city residents. "For bike share schemes to be seen as a real public transport solution and a smart answer to urban mobility, they need to work as good or better than existing public transport services," said Paul Stratta, [14].

Each city is different, with hundreds of different parameters, such as the amount of public transport available, the number of train and bus stations, the weather, the topography [14].

Towns on Finnish growth corridor have systematically developed biking ecosystem based on the strategy about open data utilization and development work.

Piloting study which took place in 2019 and some other experiences in Finland shows that the capacity utilization of bikes in depending on:

- How city bike system is connected to the rest of public transport systems (timetables, payment systems, etc.) and MaaS (mobility as a service). This indicates efficiency of mobility chain. 
- Bike operators' maintenance system is able to keep its service level agreement (SLA)

- Environment maintenance system to support the biking infrastructure (eg. biking roads, winter maintenance etc.

- On line information sharing for customer/bikers, eg. availability of bikes on a station, winter maintenance information (which) road are open from snow for biking, general data about collected information which is relevant for biker.

- Data for decision making., eg. BI-analysis (data which can be used to improve customer satisfaction and performance indicators and foresee the changes for need of bikes eg. change of season, end of tourist season, happenings, weather, etc.

- Personalized value-added services for biker, which are based on the open data provided by city bike system. (eg. biking as part of daily health care and exercise)

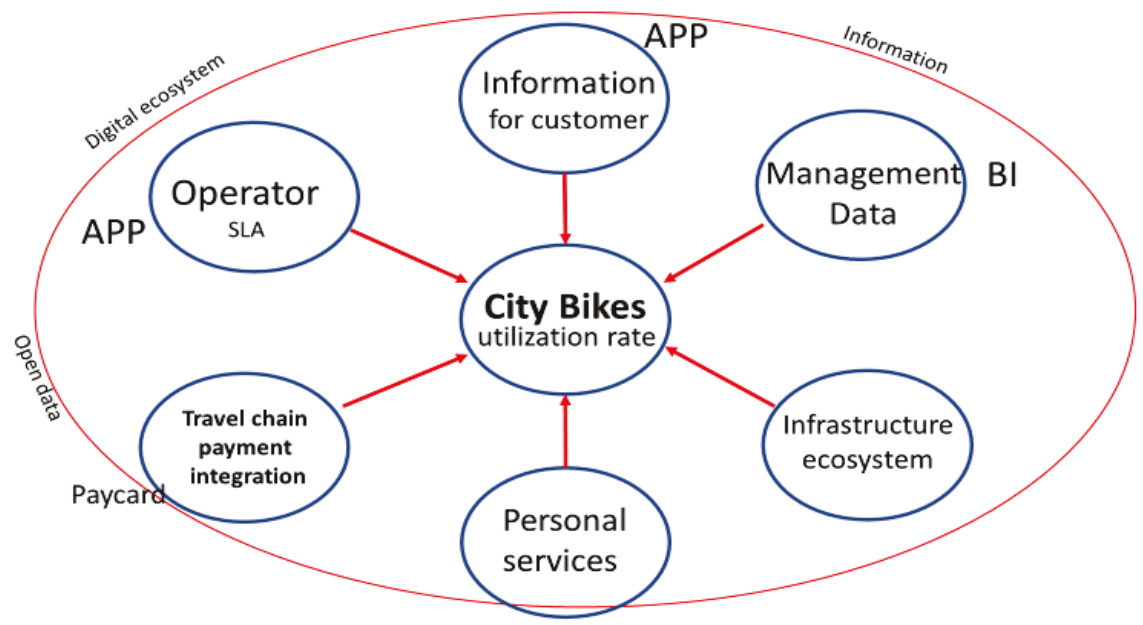

Fig. 2 The framework for City bike ecosystem at Finnish Growth Corridor cities

The biking systems in small towns are most of cases a part of the flexible mobility system. The city bike systems are usually financially supported by towns by taxpayer moneys. So, it would be wise to open the data for public use to start to develop new startups or new services for bikers.

By offering open data for biking, it is possible to create new services and support the growth of biking.

\section{Developing Intercity biking system for smoot attractive mobility}

Most of cases the cities are doing their decision about city bikes in order to improve local mobility or increase satisfaction of citizens. 
On Finnish Growth Corridor these towns are marketing their locations and city as a good environment to have home or good place to work. One of the key issues is that there is railway station and good connection from and to Helsinki. Anyhow there has not been too much discussion about the "last mile" mobility in both ends (fig. 3).

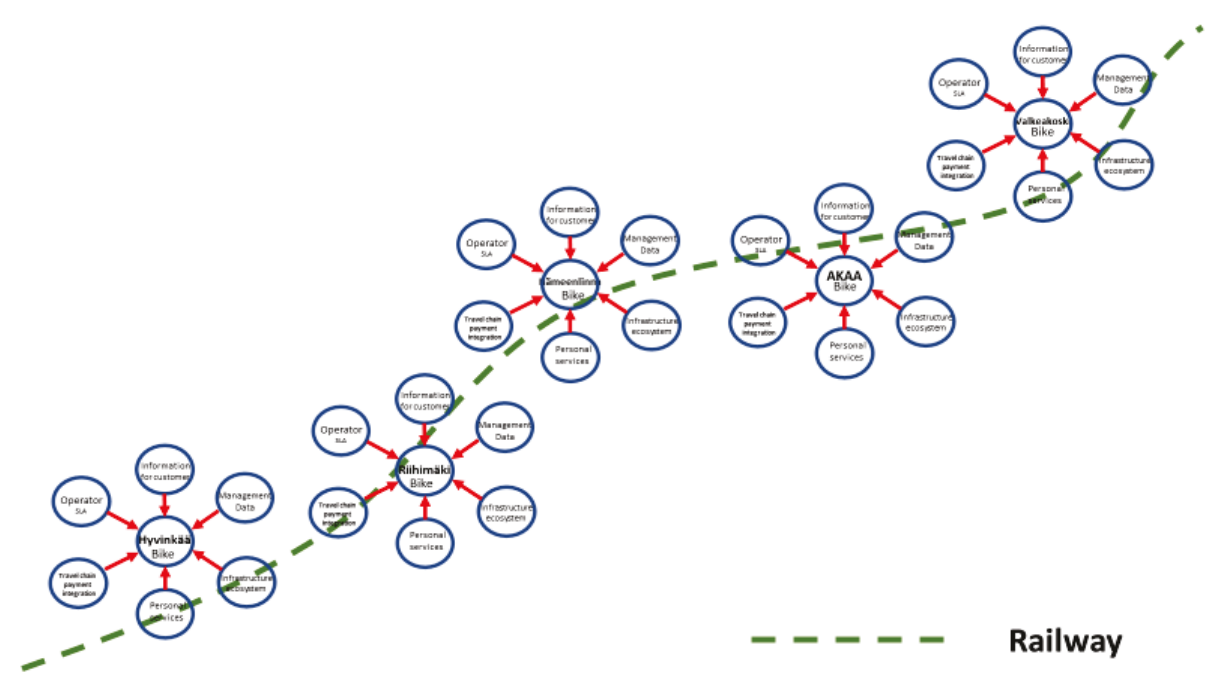

Fig 3 Last mile of mobility chain in towns and ecosystems on the growth corridor.

Towns are different and they have different needs and interest, but they have also common interests, which could bring value for all without extra expenses. If towns on Finnish Growth Corridor could be willing to adapt similar kind of data format and share the information for public use, there would be possible to create Growth Corridor standardized approach how city bike systems are connected to together.

This would provide:

- more flexible travelling chains

- better customer service

- better capability to reach the environment friendly mobility

- better capacity utilization of city bike systems

- less expenses

- collected data on growth corridor provides new opportunities for innovation.

In order to have these benefits the towns and municipalities should agree main principles about standardization of data ownership of data and the sharing the data, for new innovations.

The bikes are usually purchased or rented from operators which provides bikes as a service. These operators have also their payment systems and as well, they have their way to collect the data. 
There is a lot of discussion of having common bike system for whole growth corridor, but various towns should make choices about bike systems together and with agreed rules.

To agree this kind of standard approach would not increase the expenses for towns nor for suppliers but would provide great opportunities to use data and create larger corridor wide competences and over all bike system efficiency and capacity utilization.

As well, open data, and standardized system would provide fundament for new services and new startups on towns on Growth Corridor.

\section{Discussion and Conclusions}

City bike systems are coming more and more popular in bigger cities and can provide pollution free and flexible way to move from place to another. Anyhow there has not been much discussion about the ecosystems around city biking in rather small cities or intercity travelling by using bikes.

In the center of whole the intercity biking ecosystem and capacity utilization is the digital human- oriented experience.

To develop attractive biking concept for most of the towns on Finnish growth corridor town, there is need to have common understanding about the rules and the key indicators, To shape common vision about bike system can easily considered to be quite complicated, since every town has its own interest, own goals, own transportation system, own topology, own roads etc. own decision make process. Thus, is quite difficult to find one and only solution which would fit for every city best possible way and response future needs.

So, there is justified argument that towns should be able to manage their transportation based on their own understanding and interest.

On the other hand, all city bike systems will send quite a lot data that could be used for decision making on town level. If this data would be combined to the data of other town, that would give wider understanding for decision making on Finnish Growth Corridor

There is also common interest to use all possible element to improve the capacity utilization of city bikes because it would increase the supply of city bikes and lead to harmonization of data in every towns' own ecosystem.

The needs of bikes are depending from many factors and as well common profitability. This kind of factors are seasons, happenings, weather, etc. That is the reason why data should be collected on the all towns on growth corridor.

As a conclusion, city bike systems should be designed based on town's own need, but the use of data should be harmonized also for payment systems. Anyhow it is very important 
to notice that decision for data harmonization has been done before the decision about biking system supplier has decided.

\section{References}

1. Racontour, (Sep 11 2018). MaaS: Changing the way you travel. https://www.raconteur.net/technology/maas-changing-travel

2. LVM Ministry of transportation and communication (2019) https://www.lvm.fi/en/services

3. Peris-Ortiz, Marta; Bennett, Dag R.; Yábar, Diana Pérez-Bustamante (2016). Sustainable Smart Cities: Creating Spaces for Technological, Social and Business Development. Springer. ISBN 9783319408958.

4. Wensveen, J. G. (2015) Air transportation: A management perspective. Ashgate Publishing, Ltd.

5. ITS Finland (2019), http://www.its-finland.fi/index.php/en/palvelut/mobility-as-a-service.html

6. Rifkin, J. (2014). The Zero Marginal Cost Society: The Internet of Things, the Collaborative Commons, and the Eclipse of Capitalism. New York: St. Martin's Press.

7. Moss Kanter, R., \& Litow, S. S. (2009). Informed and Interconnected: A Manifesto for Smarter Cities. Harvard Business School Working Paper 09-141. Boston, MA: Harvard Business School

8. Salminen, V., Kantola, J., Ruohomaa, H. (2016) Digitalization and Big Data Supporting Responsible Business Co-Evolution. 2nd International Co- Evolute Conference on Human Factors, Business Management and Society (Inside AHFE 2016), Orlando, USA July 27-31, 2016.

9. Deloitte (2015) Industry 4.0 challenge: Challenges and solutions for the digital transformation and use of exponential technologies

10. PwC, (2016) 4.0 Industry: Building the digital enterprise. Global Industry Survey

11. Deloitte Rewiew, (Issue 20, 2017). The rise of mobility as a service, https://www2.deloitte.com/content/dam/Deloitte/nl/Documents/consumer-business/deloitte-nl-cb-thsrise-of-mobility-as-a-service.pdf

12. Ruohomaa, H. and Salminen, V. 2019. Mobility as a service in small cities - new concept for smart mobility in Industry 4.0 framework. ISPIM Connects, Ottawa, Innovation for Local and Global Impact, 7th-10th April 2019.

13. Kasey Panetta, Gartner, (July 12 2017). Eight Dimensions of Business Ecosystems https://www.gartner.com/smarterwithgartner/8-dimensions-of-business-ecosystems/

14. Amber Lee Dennis, (June 14, 2018). Case Study: Artificial Intelligence Helps Bike Share Programs Get Smart, https://www.dataversity.net/case-study-bike-share-programs-get-smart-artificialintelligence/?fbclid=IwAR3adaqrjlFnRInmKTEVd7XSEsVwe0ny tLWLZI4L97OgRmX8_pAowDrTK9 
164 Acta Wasaensia

\section{ORIGINAL PUBLICATION G}

Publication H. 5G as a driver for transformation of digitalization in ecosystem-based development

Authors: Heikki Ruohomaa, Vesa Salminen

AHFE2020 the San Diego, July 16-21, 2020 


\title{
5G as a driver for transition of digitalization in ecosystem-based development
}

\author{
Heikki Ruohomaa $^{1}$, Vesa Salminen ${ }^{1}$, Niklas Lähteenmäki ${ }^{2}$ \\ ${ }^{1}$ Häme University of Applied Sciences, Hämeenlinna, Finland \\ heikki.ruohomaa@hamk.fi,vesa.salminen@hamk.fi, \\ ${ }^{2}$ Hämeenlinna Town \\ niklas.lahteenmaki@hameenlinna.fi
}

\begin{abstract}
Transition towards new ICT based technologies, as 5G- related technologies, will happen unexpected fast, including exponential growth of data. It is essential to understand the challenges of change and have a strategic view, identify the key elements and see the new opportunities in all levels of society development.

5G technologies are not fully standardized until during year 2020. Many key elements and benefits as increased latency, speed and reliability have been identified. It has not been too much discussion about the implementation on the technologies that are boosted by $5 \mathrm{G}$. The development is very much depending on fiber network infrastructure investment.

Transdisciplinary innovation happens through digital innovation ecosystem to create profitable new business models. $5 \mathrm{G}$ do not replace other technologies but instead gives new possibilities for digital ecosystems to make new opportunities for business ecosystems to create new services.

There has been research about $5 \mathrm{G}$ possibilities in Smart city context in big cities, but not on what it provides in small cities. In this article is introduced the approach, how to prepare the $5 \mathrm{G}$ technology and the possibilities it may provide on Finnish growth corridor on city environment.
\end{abstract}

Keywords: smart city ecosystem $\cdot$ digitalization fiber network $\cdot 5 \mathrm{G} \cdot$ transdisciplinary innovation

\section{Introduction}

Smart cities offer the promise of safer, prosperous and more livable communities for all their citizens. To attain these benefits, smart city initiatives need a strong foundation: a high-performance network [1]. 5G could enable a new wave of technologies and applications, based on its novel infrastructure for smart cities, advanced manufacturing, healthcare systems and connected cars [2]. Industry is driven by a constant requirement for productivity. All means are sought to produce and deliver goods and services most efficiently. Growth in productivity is among the leading indicators of economic value and a strong measure of progress in the industrial age.

Yet, in the last few decades, productivity growth has slowed dramatically. That has given the unprecedented advancements for information and communications technology. After all, we have witnessed massive innovation in the Internet era and the digital transformation of enterprises is well underway [3].

Now $5 \mathrm{G}$ technologies are just developing and becoming to wider use around the word. Even big $5 \mathrm{G}$ technology providers or operator are not able to give accurate prediction, how fast the development of $5 \mathrm{G}$ development will be. Nokia has in its predictions expected $5 \mathrm{G}$ technologies to be as fast and similar as LTE technologies development. 
Even if there is not a clear idea how fast the change will be or how it will happen there are no doubts that the change will be enormous. It is important to understand how cities and industries should be prepared for that change.

$5 \mathrm{G}$ does not replace old technologies but gives new opportunities for new technologies. $5 \mathrm{G}$ may also boost the use of old technologies. There will also be solutions for which 5G does not provide anything beneficial. It is important to create benefit of $5 \mathrm{G}$, not only for big cities, but also in countryside and small villages. It is predicted that the $5 \mathrm{G}$ technology will be utilized first in industry. In other sectors, $5 \mathrm{G}$ networks are becoming more common as the benefits and applications of $5 \mathrm{G}$ in different sectors become more concrete. As a rule, $5 \mathrm{G}$ has been designed for a much more versatile use than the previous GSM generations. It is challenging to identify uses for which $5 \mathrm{G}$ is not suitable [4].

On the discussion about $5 \mathrm{G}$, the question is not about the technology itself, but how to manage the change so that it will be beneficial for whole society on sustainable way. It is important to achieve an excellent digital human user experience by implementing 5Gtechnologies.

\section{Theoretical Framework}

Major global challenges, such as globalization, climate change and digitalization. are influencing on societies, cities and regions as well as on industries. Today, $55 \%$ of the world's population lives in urban areas, a proportion that is expected to increase to $68 \%$ by 2050 [5].

The key features of $5 \mathrm{G}$ are high capacity, low latency, and the ability to connect a massive number of IoT sensors to the network. In addition, compared with the previous network generations, the $5 \mathrm{G}$ network makes it possible to implement tailored web services for different needs.

It is becoming clear that $5 \mathrm{G}$ will cost much more to deploy than previous mobile technologies (perhaps three times as much), as it is more complex and requires a denser coverage of base stations to provide the expected capacity. The European Commission has estimated that it will cost $€ 500$ billion to meet its 2025 connectivity targets, which includes $5 \mathrm{G}$ coverage in all urban areas [6].

5G is driven by the telecom supply industry and its long tail of component manufacturers. Their major campaign is under way to convince governments that the economy and jobs will be strongly stimulated by $5 \mathrm{G}$ deployment. However, we have not yet seen significant "demand-pull" that could assure sales. These campaign efforts are also aimed at the MNOs but they have limited capacity to invest in the new technology and infrastructure as their returns from investment in $3 \mathrm{G}$ and $4 \mathrm{G}$ are still being recouped [6].

The capacity of 5G network serves exponentially accelerating growth of data. Low latency, in turn, is important in many different sectors. An example is AI applications, which must be able to react to different situations in real time, for example in industrial processes. Latency is also of high importance in the remote control of self-directed vehicles and other machines and equipment. $5 \mathrm{G}$ is therefore not only a network faster than the previous 
generations but a technology that makes it possible to put many digital innovations into practical use.

Now things are changing, when industries in the "physical economy" have begun their digital transformation. It is possible to recognize the opportunity for much bigger productivity boom. Now the Internet of Things (IoT), edge computing, deep analytics based on artificial intelligence/machine learning (AI/ML), augmented reality (AR), robotics, remote control and digital twin technologies are mature enough and can reach a critical mass of adoption, the opportunities to energize traditional industries are countless.

Advances in robotics have begun to dramatically simplify the interface between digital systems and physical tasks. Technologies that can bring the physical and digital economies together will drive commercial and social value better than before. Augmented intelligence and automation will drive productivity while dramatically reducing risks [7].

The strength of the international GSM ecosystem has always been agreeing on international standards and sticking to them. From industrial point of view it is important to ensure that this will continue. Global compatibility is an absolute prerequisite for the exploitation of technology, and it is also a common interest for all the industries. In this sense, the $5 \mathrm{G}$ network will be built in the same way as the previous network generations. Holma and Poikselkä [8] have introduced an overview of the different 5G architectures and then cover in more details the radio access network (RAN) architecture and interfaces as well as the $5 \mathrm{G}$ Core $(5 \mathrm{GC})$ network with key elements and functionalities.

Operators network is an ecosystem where companies and organizations together develop $5 \mathrm{G}$ uses. The network gives you the possibility to share knowledge and create innovations with players of different industries, and the members include companies, public sector organizations and startups. The members of the network will be among the first to take advantage of the opportunities offered by $5 \mathrm{G}$ and of related information [4]. The future $5 \mathrm{G}$ transport networks are envisioned to support a variety of vertical services through network slicing and efficient orchestration over multiple administrative domains [9].

The move to Industry 4.0 and the ongoing transformation of enterprises to adopt cloud, IoT and advanced wireless networking options is a massive undertaking [10]. It will demand strong partnerships with industry, and ecosystems that are at once more diverse and more cohesive than we have ever seen before. As such, Nokia is actively engaged in catalyzing, developing and joining the ecosystems and consortia that will drive specific industries to accelerated benefits [1].

\section{Research approach}

$5 \mathrm{G}$ - The smart city concept integrates the information and communication technology (ICT), physical Internet of things, and IoT-devices to optimize the efficiency of city operations and services [11].

$5 \mathrm{G}$ and other new technologies and huge amount of data forces also organizations to change. That is the reason why many cities are developing their activities towards smart city concept and taking use to $5 \mathrm{G}$ technologies by having ecosystem-based development.

Research questions of this study are: 
1. How 5G- technology is influencing on holistic development of society activities?

2. How is ecosystem based innovation, learning and business transition occurring?

3. How 5G- technology is reacting on various ecosystem development layers?

4. How is digital and human user experience achieved when implementing 5Gtechnologies

In this study has been used qualitative and case study research approach. This article introduces 5G development in smart cities - new concept for small towns in 5G framework. It provides a case study as a part of Hämeenlinna city ecosystem- based development.

\section{5G ecosystem-based development in Small City and Smart Countryside environment}

Global demographics are rapidly changing. According to the latest United Nations report, more than two-thirds of the world's population will be living in urban areas by 2050. In addition, a World Economic Forum article states that, for the first time in human history, there are now more people over the age of 65 than under the age of 5 .

A confluence of these inexorable trends of urbanization and population change put immense strains on city infrastructure and services and has triggered the concept of the smart city for a safer, more sustainable and livable community.

Consequently, cities are embracing innovative smart city applications to automate and optimize the operation of their underlying infrastructure and services, from street lighting and CCTV to air-quality sensors, traffic management and emergency services. By improving the performance of infrastructure and services, smart cities also improve citizens' quality of life and foster higher economic growth.

New innovations are based on increasing amount of data, use of new technologies and understanding of new needs of customers. That is the reason there is need for "real life" testing, piloting and developing environment. Including this, ecosystem-based development work is needed when the environment is fast changing and complex.

The utilization of $5 \mathrm{G}$ has started and it has expected to bring new business opportunities and the development for new business models. Anyhow there is need to remember that $5 \mathrm{G}$ technology is just technology for data transfer, which need a fiber network and broad stations to support it. We can consider the $5 \mathrm{G}$ as an infrastructure or a fundament for the utilization of 4IR technologies.

The harmonization of data and standardization of new technologies will give the possibilities for developing new digital ecosystems. It will give fundament and new possibilities, when benefitting $5 \mathrm{G}$, for new innovations and business models. When taking $5 \mathrm{G}$ into use, it is important to see the development action of 5G on different each other's interacting ecosystem layers 


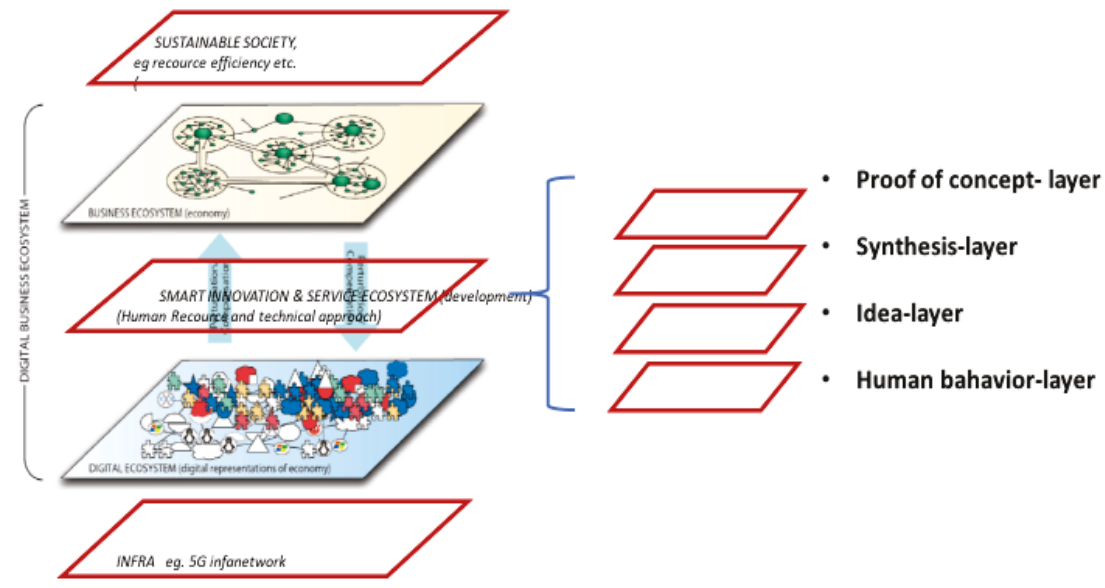

Fig 1. Different layers of smart city development- $5 \mathrm{G}$ as fundament of development

Different layers of ecosystems on $5 \mathrm{G}$ development are described in the figure 1 . They will give the frameworks and vision for development.

The meaning of various layers and related ecosystems are descripted as following:

Infrastructure -layer is fundament for $5 \mathrm{G}$, which provides infrastructure for fast data transfer. The fiber network and broad base stations form this infrastructure. The availability of fiber network and the density of stations will provide the possibilities for the region. The existence and the reliability are the fundament for all development.

On Digital ecosystem-layer the key issue is the standardization of technology and harmonization of data, so that data can be used in the best possible way.

Innovation layer is for the development of a new innovation and implementing possibilities. Innovation process on this layer is divided into four sections, which are: a. human behavior, b idea, c. synthesis, d. proof of concept (POC).

On Business ecosystem layer new business and new business models will take place and new startups take birth. The core purpose on business ecosystem is to create profitable business.

In this article the purpose of Sustainable ecosystems layer is in decision making process. It will give impact on the actions that is expected. This kind of actions are eg. land use planning, building fiber network, open data, taxation, regulations etc., which are supporting the attractiveness of a region. 


\section{Innovation process}

Since the change will be fast and complex, development work has to happen in a "real life" environment. As well, it is impossible to determine all the possible options. Thus, the quick pilots in real life environments are essentials for development.

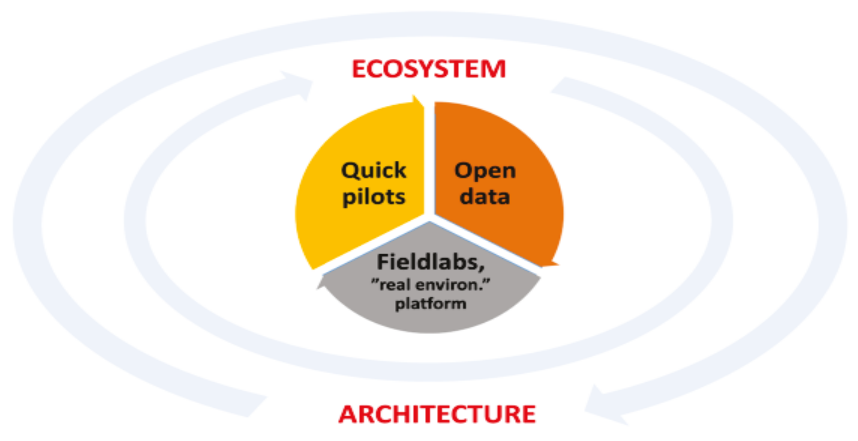

Figure 2. The birth of innovation in digital ecosystem

Ruohomaa and Salminen [12] have introduced a model for ecosystem-based development using open data and quick pilots in real live environments. In this framework the role of new innovations and innovation process is very important, because it is a key issue on transition process in the environment of new technologies.

\section{The pillars of Hämeenlinna development}

Hämeenlinna town is located on the Growth Corridor of Finland. The main part of population, and economic activities in Finland are located on Finnish growth corridor. The key goal for Hämeenlinna town is to increase its attractiveness, imago and improve the competitiveness of the town, Because of these reasons Hämeenlinna is in its own development work and strategy focusing on:

1.) ecosystem-based development

2.) open data environment

3.) "Railway station environment" part of city as a piloting environment as fieldlab

4.) quick pilots

In order to response the development need of 5G, Hämeenlinna town is executing economy system-based development with the elements of Smart city concept. New 4RI technologies do not replace old technologies very fast, but the use of present technologies will supplement more and improve. That's why $5 \mathrm{G}$ should be seen as technology which improves and boosts development.

When new and present technology and increasing amount of data have been brought on the same platform, it will be possible to see the problems in solving and making improvements in interoperability and identify lack of standardization. 


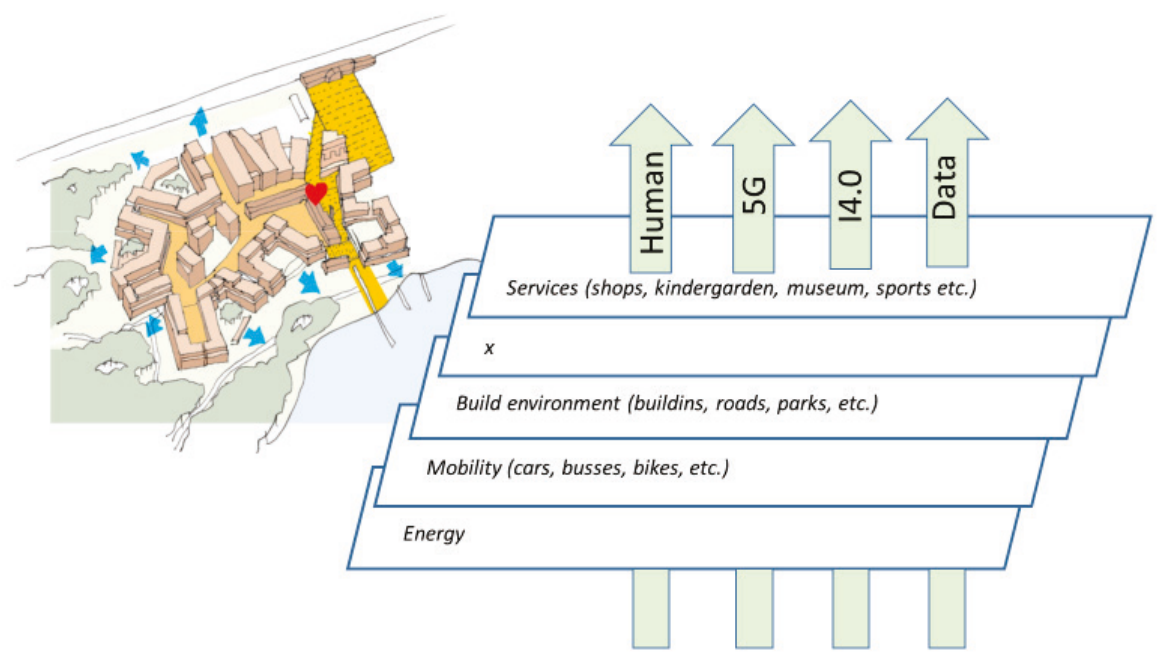

Fig 3. Ecosystem based innovation platform

Ruohomaa and Salminen [12] have introduced that ecosystem based city development needs innovation platform (fig 3.). Building blocks are a common platform, common technology, common architecture, sharing data and also common goal. Innovations are created on the interfaces of various partners from different domains.

Smart City development can also be shown as the way that 5G infrastructure has to be present in the all different activities/operation of city level. Harmonization of data and the availability of open data are essential on development work.

5G technology is important for applications. Artificial intelligence, robots, selfdirected vehicles or applications with remotely controlled devices are required to react to different situations without delay and in real time. For example, when two AI applications communicate with each other, it is necessary to have fast and latency-free data transfer. The AI application must also be able to react to different situations in real time. If artificial intelligence analyses video or other footage, it should be of high quality. This will require a high data transmission capacity.

Latency is a significant factor in remote controlled devices. A device or machine must be able to react to remotely given commands in almost real time. The same applies to selfdirected vehicles. In the event of a problem, for example, it must be possible to intervene in the driving in real time.

Self-directed vehicles will also collect a lot of data on their environment. 5G network capacity is required, when data is to be transferred to data center for analysis [4]

The Future $\mathbf{X}$ architecture [1] harnesses technologies such as Industrial Internet of Things, edge computing, cloud, artificial intelligence, machine learning, augmented and virtual reality, and high-performance networking - including 5G - to drive dramatic productivity improvements across a wide range of industrial sectors. 
With the Future $\mathbf{X}$ for Smart Cities architecture, you can enable the human possibilities of smart cities by interconnecting your systems, processes, activities and citizens. The opportunities and benefits are:

- Ease the flow of cars and people with smart mobility services. Simplify bus connections. Offer a real-time view of available parking. Monitor crowds in public venues.

- Use energy resources more efficiently in homes and businesses, as well as for public lighting.

- Enhance public safety with video-surveillance analytics, an integrated command and control center, and enhanced communications for first responders.

- Improve healthcare in your city with remote monitoring applications, while keeping costs under control.

- Enhance the fun and safety of large events and improve the tourist experience.

-

\section{Conclusions}

$5 \mathrm{G}$ is for sure the key element for the development of the technologies in the fourth industrial revolution. The key issue is fiber network and stations, which could be seen as the infrastructure of digital communication. Especially the availability on fiber network in rural areas is the key issue to have reasonable environment for development of $5 \mathrm{G}$ based activities.

Since the speed of digital transition is fast, it is important to have a clear vision, which gives direction for development, since the new technologies are continuously developing. There is neither clear understanding about the outcome nor the new business models which will take place in future.

Since the new technologies have strong focus on inter-compatibility, it is essential that there will be ecosystem-based development. It will make complex and fast changing world development activities possible. It is also essential to have "real life" testing, piloting and learning environment.

Industry 4.0 technologies are developing, but they are not completely ready yet. So old technologies will be usable for a long time. Change will not happen "overnight", even if the change is fast. Many of the new technologies are working already in a reasonable way on $4 \mathrm{G}$ connection, so these technologies should be actively studies.

\section{References}

1. Nokia 2019/1, Laying the foundation of a smart city https://onestore.nokia.com/asset/206572

2. Nokia 2019/2, Nokia Bell Labs Future X for Smart Cities architecture https://www.nokia.com/networks/industries/smart-city/

3. Nokia 2019/3 White paper https://www.nokia.com/blog/meet-1000-year-old-city-futurewroclaw-polandtaking-smart-city-new-level/

4. Telia 2019 what are $5 \mathrm{G}$ questions and answers https://www.telia.fi/en/yrityksille/article/5g-questions-and-answers

5. United Nations (2018 May 15). https://www.un.org/development/desa/en/news/population/2018revision-of-world- urbanization-prospects.html

6. Blackman, C., Forge, S. (2019) 5G Deployment: State of Play in Europe, USA and Asia, Study for the Committee on Industry, Research and Energy, Policy Department for Economic, Scientific and Quality of Life Policies, European Parliament, Luxembourg, 2019. 1 
7. Networking solutions for the new age of industry https://onestore.nokia.com/asset/2057091

8. Holma, H., Poikselkä, M. (2019) 5G Architecture. 5G Technology: 3GPP New Radio, Book edited by Holma H., Toskala A. and Nakamura T., John Wiley \& Sons Ltd. December 2019. Print ISBN:9781119236313. 1

9. Antevski, K., Perez, J., Molner, N., Gharbaoui, M. (2018) Resource Orchestration of 5G Transport Networks for Vertical Industries. Conference: 2018 IEEE 29th Annual International Symposium on Personal, Indoor and Mobile Radio Communications (PIMRC), September 2018.

10. IoT Community 2019, http://iotcommunity.com/the-program/

11. Peris-Ortiz, Marta; Bennett, Dag R.; Yábar, Diana Pérez-Bustamante (2016). Sustainable Smart Cities: Creating Spaces for Technological, Social and Business Development. Springer. ISBN 9783319408958.

12. Ruohomaa, H., Salminen, V, (2019) Mobility as a service in smart cities - new consept for smart mobility in Industry 4.0 framework. ISPIM Connects Ottawa, Ottawa, Canada on 7-10 April 2019. The publication is available to ISPIM members at www.ispim.org. 